\title{
The structural basis of function in Cys-loop receptors
}

\author{
Andrew J. Thompson', Henry A. Lester ${ }^{2}$ and Sarah C. R. Lummis' \\ ' Department of Biochemistry, University of Cambridge, Building O, Downing Site, Cambridge CB2 IQW, UK \\ ${ }^{2}$ California Institute of Technology, I 200 East California Boulevard, Pasadena, CA 9| I25, USA
}

\begin{abstract}
Cys-loop receptors are membrane-spanning neurotransmitter-gated ion channels that are responsible for fast excitatory and inhibitory transmission in the peripheral and central nervous systems. The best studied members of the Cys-loop family are nACh, 5- $\mathrm{HT}_{3}$, $G_{A B A}$ and glycine receptors. All these receptors share a common structure of five subunits, pseudo-symmetrically arranged to form a rosette with a central ion-conducting pore. Some are cation selective (e.g. $\mathrm{nACh}$ and $5-\mathrm{HT}_{3}$ ) and some are anion selective (e.g. GABA $\mathrm{A}_{\mathrm{A}}$ and glycine). Each receptor has an extracellular domain (ECD) that contains the ligand-binding sites, a transmembrane domain (TMD) that allows ions to pass across the membrane, and an intracellular domain (ICD) that plays a role in channel conductance and receptor modulation. Cys-loop receptors are the targets for many currently used clinically relevant drugs (e.g. benzodiazepines and anaesthetics). Understanding the molecular mechanisms of these receptors could therefore provide the catalyst for further development in this field, as well as promoting the development of experimental techniques for other areas of neuroscience.

In this review, we present our current understanding of Cys-loop receptor structure and function. The ECD has been extensively studied. Research in this area has been stimulated in recent years by the publication of high-resolution structures of nACh receptors and related proteins, which have permitted the creation of many Cys loop receptor homology models of this region. Here, using the $5-\mathrm{HT}_{3}$ receptor as a typical member of the family, we describe how homology modelling and ligand docking can provide useful but not definitive information about ligand interactions. We briefly consider some of the many Cys-loop receptors modulators. We discuss the current understanding of the structure of the TMD, and how this links to the ECD to allow channel gating, and consider the roles of the ICD, whose structure is poorly understood. We also describe some of the current methods that are beginning to reveal the differences between different receptor states, and may ultimately show structural details of transitions between them.
\end{abstract}

\section{Introduction 450}

\section{Subunit stoichiometry $45 \mathrm{I}$}

\section{The ECD 453}

3.1. Structure 453

3.2. The ligand-binding site 455

3.2.1. Ligand binding; in silico predictions from the $5-\mathrm{HT}_{3} \mathrm{R} \quad 458$

* Author for correspondence: Sarah C. R. Lummis, Department of Biochemistry, University of Cambridge, Building O Downing Site, Cambridge CB2 1QW, UK.

Tel.: 01223 333600; Fax: 01223 333345; Email: s1120@cam.ac.uk 
3.2.2. Ligand binding; experimental evidence for the $5-\mathrm{HT}_{3} \mathrm{R}$ in silico predictions 462

3.2.3. Ligand binding: summary 465

3.3. Allosteric modulation 465

3.3.I. Ions as modulators 467

3.3.2. Benzodiazepines 467

3.3.3. Alcohols and anaesthetics 468

3.3.4. Ivermectin - a commercially important modulator of invertebrate $\mathrm{GluCl}$ receptors 468

3.3.5. $\alpha 7$ nACh receptor allosteric modulators 469

\section{The TMD 469}

4.I. Structure 469

4.2. $\mathrm{MI}$ and the $\mathrm{MI}-\mathrm{M} 2$ loop $47 \mathrm{I}$

4.3. $M 2$ lines the channel pore and acts as the channel gate 471

4.4. $M 2$ and ion selectivity 473

4.5. The M2-M3 loop 474

4.6. $M 3$ and M4 helices 475

\section{The ICD 475}

5.1. Structure 475

5.2. Channel conductance 476

5.3. Intracellular modulation 476

\section{Molecular basis of Cys-loop receptor activation 477}

\section{Time-resolved structural information $\mathbf{4 7 8}$}
7.1. Time-resolved cryo-electron microscopy 478
7.2. Time-resolved mass spectrometry 479
7.3. Light-flash relaxations 479
7.4. Rate-equilibrium free energy relationships 480
7.5. Voltage-clamp fluorometry 480
7.6. Total internal reflection fluorescence 482

\section{Conclusions 482}

\section{Acknowledgements 483}

\section{References 483}

\section{Introduction}

Cys-loop ligand-gated ion channels (LGICs) are membrane-spanning proteins that are activated by neurotransmitters; they are responsible for fast excitatory and inhibitory neurotransmission in the central and peripheral nervous systems. Vertebrate members of this family include serotonin (5- $\mathrm{HT}_{3}$ ), acetylcholine (nicotinic ACh or nACh), glycine (Gly), $\gamma$-aminobutyric acid $\left(\mathrm{GABA}_{\mathrm{A}}\right.$, $\mathrm{GABA}_{\mathrm{C}}$ ) and zinc-activated (ZAC) receptors $(\mathrm{R})$. There are also a range of invertebrate Cys-loop receptors gated by the same and other neurotransmitters (e.g. EXP-1, MOD-1, pHCl, HisCl, $\mathrm{RDL}, \mathrm{GluCl}$ and $\mathrm{SsCl}$ ), and related proteins have been identified in prokaryotes (e.g. ELIC and GLIC). Cys-loop receptors are the major targets for many active compounds, including anaesthetics, muscle relaxants, insecticides and a range of drugs that treat neurological disorders such as Alzheimer's, anxiety, epilepsy, learning, attention deficit and drug addiction. Methods such as high throughput screening (HTS) and fragment-based drug discovery (FBDD) use blind searches 
of large compound libraries to find drug candidates, but a rational design of more effective drugs requires a detailed molecular knowledge of the sites at which they act. For Cys-loop receptors, this information lags behind that of many other proteins.

Cys-loop receptors derive their name from a 13-amino-acid loop within the extracellular domain (ECD) that is enclosed by a pair of disulphide-bonded Cys residues. Members of the family share a common structure, consisting of five pseudo-symmetrically arranged subunits surrounding a central ion-conducting pore (Fig. 1). Most receptors have more than one type of subunit, and these can combine in different combinations to yield a complex array of (usually) heteromeric receptor stoichiometries, with varying physiological and pharmacological properties. Each receptor family is selective for either cations or anions, and their activation can be either excitatory or inhibitory, depending on the distribution of ions at either side of the membrane, and the membrane potential of the cell. The structure of the subunits has been studied using a variety of biochemical techniques such as mutagenesis, photolabelling and cryo-electron microscopy, and more recently by X-ray crystallography. Each subunit can be functionally separated into three domains: The large ECD contains the ligand-binding site and is a major target for therapeutics. The transmembrane domain (TMD) consists of four membrane-spanning $\alpha$-helices (M1-M4) that enable ions to cross the membrane and is the target for compounds such as alcohols, anaesthetics and steroids. The intracellular domain (ICD) is primarily formed by the large M3-M4 intracellular loop ( 100-270 residues), and is responsible for receptor modulation, sorting and trafficking, and contains portals (openings) that allow ions access in and out of the pore and influence ion conductance. Recent studies have described homologous bacterial proteins that do not possess a Cys-loop or an ICD, and deletion studies in the $5-\mathrm{HT}_{3} \mathrm{R}$ and $\mathrm{GABA}_{\mathrm{C}} \mathrm{R}$ suggest that the ICD is not essential for the expression of vertebrate receptors (Bocquet et al. 2007; Jansen et al. 2008).

In summary, all Cys-loop receptors share homologous structures, and the basic mechanisms by which they function are also similar. In this review, we look at all members of the family, although concentrating largely on the $5-\mathrm{HT}_{3} \mathrm{R}$, to explore the relationship between structure and function. The $5-\mathrm{HT}_{3} \mathrm{R}$ is a typical Cys-loop receptor, and has the advantage that it functions as a homomeric receptor, which simplifies the interpretation of experimental data. This protein has also been used extensively in homology modelling and ligand docking (Maksay et al. 2003; Reeves et al. 2003; Thompson et al. 2005; Yan \& White, 2005). As this technique is becoming an accepted route to understanding the structural details of the proteins, we use the new homology models and docked ligands to explore the validity of these techniques to define specific molecular interactions with agonists and antagonists in the 5- $\mathrm{HT}_{3}$ ligand-binding site.

For further reading, a number of recent reviews also cover some of the topics discussed here (Arias, 2006; Auerbach, 2010; Barnes et al. 2009; Chen, 2010; Corringer et al. 2010; Hogg et al. 2003; Lynch, 2004, 2009; Millar \& Gotti, 2009; Peters et al. 2005, 2010; Webb \& Lynch, 2007; Yakel, 2010).

\section{Subunit stoichiometry}

The stoichiometry of the neuromuscular $\mathrm{nAChR}$ was the first to be determined, and revealed that four different subunits formed a functional pentameric receptor with the stoichiometry $\alpha_{2} \beta \gamma \delta$ (Karlin et al. 1983). Determining the stoichiometry of other receptors has proved to be more problematic, as there are large numbers of subunits that could potentially contribute (e.g. 19 in the $\mathrm{GABA}_{\mathrm{A}}$ receptor family), and it is becoming apparent that different arrangements 


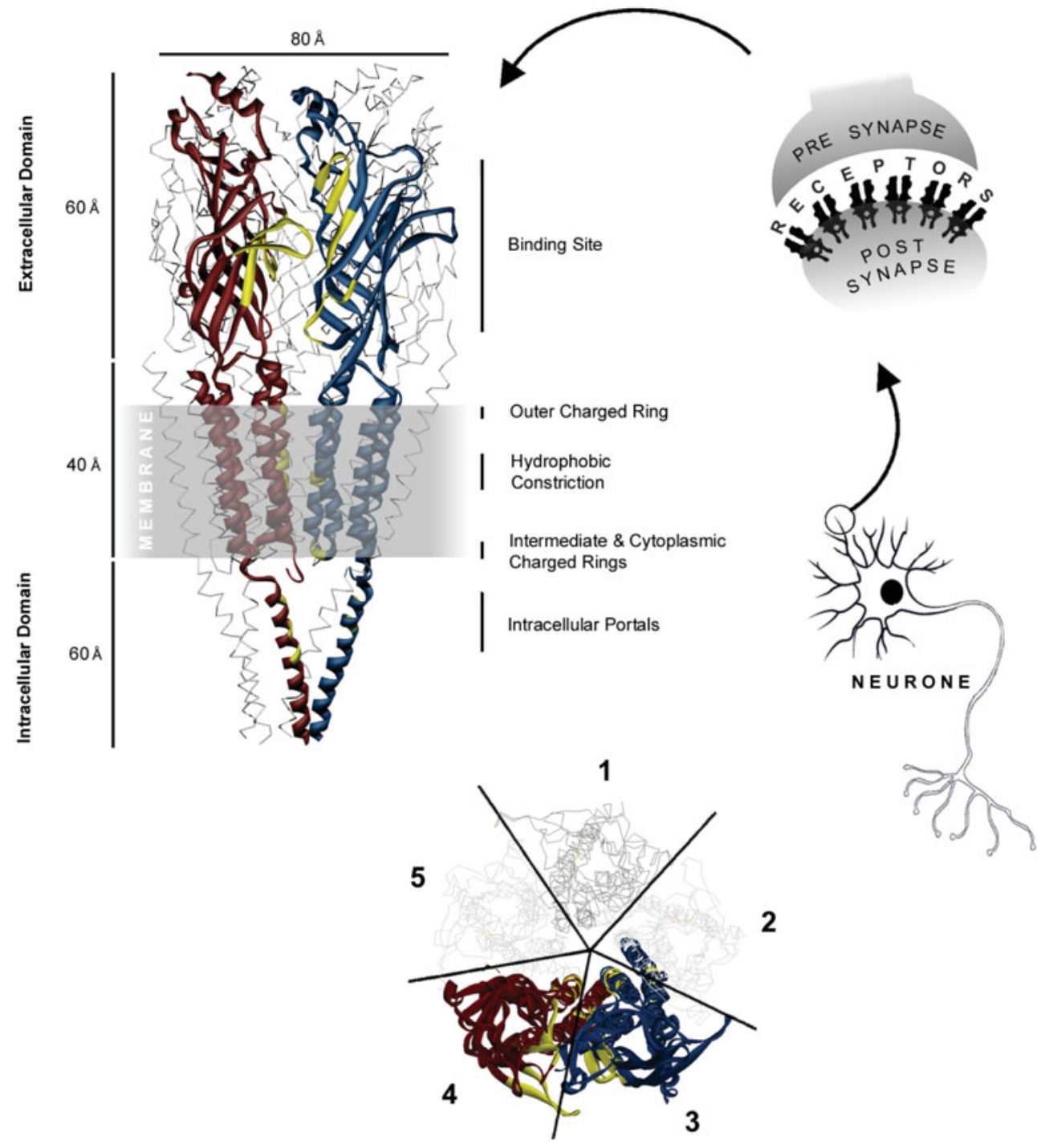

Fig. 1. Important functional components of the $5-\mathrm{HT}_{3}$ receptor, a typical member of the Cys-loop family of LGICs. The structure shown is a $5-\mathrm{HT}_{3}$ homology model based on a $4 \AA$-resolution structure of the $\mathrm{nAChR}$ (Miyazawa et al. 2003; PDB ID: 2BG9). The 5- $\mathrm{HT}_{3}$ receptor, like the other members, consists of five subunits (1-5). The receptor is shown from above and from the side with two (red \& blue) of the five subunits highlighted. Specific residues of interest are highlighted in yellow. The receptor is modular in nature and can be considered as having three main regions termed the ECD, TMD and ICD. The ECD contains the ligand-binding site that is formed by the convergence of six peptide loops located at the interface of two adjacent subunits (Noam et al. 2008; Thompson \& Lummis, 2006). Three rings of charged amino acids (extracellular, intermediate and cytoplasmic) are found in the pore lining $\alpha$-helices of the TMD (Gunthorpe \& Lummis, 2001; Thompson \& Lummis, 2003), and a hydrophobic constriction in the centre of the channel acts as the channel gate (Panicker et al. 2002).

may exist even with the same subunit types (Gotti et al. 2007; Millar \& Gotti, 2009; Millar \& Harkness, 2008; Olsen \& Sieghart, 2009). For example, neuronal $\alpha 4 \beta 2 \mathrm{nAChR}$ may be $\alpha_{2} \beta_{3}$ or $\alpha_{3} \beta_{2}$, which have differing pharmacologies (Moroni \& Bermudez, 2006; Moroni et al. 2006). Studies indicate, however, that only a limited number of the possible stoichiometries are 
found in vivo, possibly because of cell-specific expression and/or interactions between subunit interfaces that form during receptor assembly (e.g. neuronal $\mathrm{GABA}_{\mathrm{A}}$ receptors are predominantly $\alpha 1_{2} \beta 2_{2} \gamma 2$ ). Receptor types may also be restricted to specific regions of the body (e.g. $\mathrm{GABA}_{\mathrm{C}}$ receptors are largely restricted to retinal bipolar cells; Cutting et al. 1991; Enz \& Cutting, 1999). Some Cys-loop receptors have considerably fewer potential stoichiometries. For example, there are only four known isoforms of the GlyR $\alpha$-subunit $(\alpha 1-\alpha 4)$ and a single $\beta$-subunit, with the probable stoichiometry of $\alpha 1_{3} \beta_{2}$ or $\alpha 1_{4} \beta$ (Lynch, 2009; Webb \& Lynch, 2007), and only a single subunit has been described for vertebrate $\mathrm{Zn}^{2+}$-activated receptors (Davies et al. 2002). Invertebrate receptors may also have multiple subunits; several glutamate-gated and $\mathrm{pHCl}$ receptor subunits have been reported, although currently there are only two known histaminegated receptor subunits (HisCl1 and $\mathrm{HisCl} 2 \mathrm{SsCl}$ ) and single $\mathrm{SsCl}$ and MOD-1 receptor subunits (Cully et al. 1996, 1994; Mounsey et al. 2007; Ranganathan et al. 2000; Zheng et al. 2002). Prokaryotic receptors discovered to date also only have single subunits, but as many of these have only recently been described, the diversity of their subunits types may grow with further investigation (Bocquet et al. 2007; Hilf \& Dutzler, 2008; Nury et al. 2009).

The $5-\mathrm{HT}_{3} \mathrm{R}$ is an example of a Cys-loop receptor with relatively few subunits; five have been identified to date (A-E), although like many other receptors, some of these demonstrate a further level of complexity that results from different splice-variations and differing post-translational modifications (Bruss et al. 2000; Tzvetkov et al. 2007; Werner et al. 1994). For example, there are long and short forms of the mouse 5-HT3A subunit that differ by six amino acids, and there are three translational variants of the human 5-HT3B subunit (Fig. 2). Only 5-HT3A subunits can form functional homomeric $5-\mathrm{HT}_{3} \mathrm{Rs}$, and appear to be obligatory in heteromeric receptors (Holbrook et al. 2009; Niesler et al. 2007). Of the heteromeric receptors, only 5- $\mathrm{HT}_{3} \mathrm{AB}$ receptors have been extensively characterized and, compared to homomeric $5-\mathrm{HT}_{3} \mathrm{~A}, 5-\mathrm{HT}_{3} \mathrm{AB}$ receptors differ in their $\mathrm{EC}_{50}$, Hill slope, desensitization kinetics, shape of current-voltage relationship, and most noticeably, a much larger single-channel conductance ( $\sim 16 \mathrm{pS}$ in $5-\mathrm{HT}_{3} \mathrm{AB}$ compared to $<1 \mathrm{pS}$ in 5- $\mathrm{HT}_{3} \mathrm{~A}$; Davies et al. 1999; Dubin et al. 1999). However, the pharmacology of $5-\mathrm{HT}_{3} \mathrm{~A}$ and $5-\mathrm{HT}_{3} \mathrm{AB}$ receptors is almost identical, suggesting that they contain a common binding site (an A-A interface), a hypothesis supported by a recent study of mouse 5- $\mathrm{HT}_{3} \mathrm{AB}$ receptors (Brady et al. 2001; Lochner \& Lummis, 2010), but conflicting with the BABBA arrangement determined using atomic force microscopy (Barrera et al. 2005). The subunit types and stoichiometry of $5-\mathrm{HT}_{3} \mathrm{Rs}$ have been recently reviewed (Barnes et al. 2009; Jensen et al. 2008).

\section{The ECD}

\section{I Structure}

Recent X-ray crystal structures of the nAChR ECD have revealed molecular details of residues that contribute to the ligand-binding domain, but such studies of whole receptors, or even ECD pentamers are proving difficult to obtain (Dellisanti et al. 2007). Therefore, most molecular details of Cys-loop receptors have been extrapolated from $4 \AA$ resolution cryo-electron microscopy images of the $\mathrm{nAChR}$, or from higher-resolution images of related acetylcholine binding proteins (AChBPs) and bacterial receptors. AChBPs are homologous to the ECD of nACh ( $\sim 25 \%$ amino-acid sequence identity) and other Cys-loop receptors (15-20\% identity). The original AChBP structure was determined at 2.7 $\AA$ resolution in 2001 (Brejc et al. 2001), and 
$5-\mathrm{HT}_{3} \mathrm{~A}$
$5-\mathrm{HT}_{3} \mathrm{AL}$
$5-\mathrm{HT}_{3} \mathrm{AT}$
$5-\mathrm{HT}_{3} \mathrm{~B}$
$5-\mathrm{HT}_{3} \mathrm{BR} 1$
$5-\mathrm{HT}_{3} \mathrm{BR} 2$
$5-\mathrm{HT}_{3} \mathrm{C}$
$5-\mathrm{HT}_{3} \mathrm{D}$
$5-\mathrm{HT}_{3} \mathrm{E}$

$5-\mathrm{HT}_{3} \mathrm{~A}$

$5-\mathrm{HT}_{3} \mathrm{AL}$

$5-\mathrm{HT}_{3} \mathrm{AT}$

$5-\mathrm{HT}_{3} \mathrm{~B}$

$5-\mathrm{HT}_{3} \mathrm{BR} 1$

$5-\mathrm{HT}_{3} \mathrm{BR} 2$

$5-\mathrm{HT}_{3} \mathrm{C}$

$5-\mathrm{HT}_{3} \mathrm{D}$

$5-\mathrm{HT}_{3} \mathrm{E}$

$5-\mathrm{HT}_{3} \mathrm{~A}$

$5-\mathrm{HT}_{3} \mathrm{AL}$

$5-\mathrm{HT}_{3} \mathrm{AT}$

$5-\mathrm{HT}_{3} \mathrm{~B}$

$5-\mathrm{HT}_{3} \mathrm{BR} 1$

$5-\mathrm{HT}_{3} \mathrm{BR} 2$

$5-\mathrm{HT}_{3} \mathrm{C}$

$5-\mathrm{HT}_{3} \mathrm{D}$

$5-\mathrm{HT}_{3} \mathrm{E}$

$5-\mathrm{HT}_{3} \mathrm{~A}$

$5-\mathrm{HT}_{3} \mathrm{AL}$

$5-\mathrm{HT}_{3} \mathrm{AT}$

$5-\mathrm{HT}_{3} \mathrm{~B}$

$5-\mathrm{HT}_{3} \mathrm{BR} 1$

$5-\mathrm{HT}_{3} \mathrm{BR} 2$

$5-\mathrm{HT}_{3} \mathrm{C}$

$5-\mathrm{HT}_{3} \mathrm{D}$

$5-\mathrm{HT}_{3} \mathrm{E}$

$5-\mathrm{HT}_{3} \mathrm{~A}$

$5-\mathrm{HT}_{3} \mathrm{AL}$

$5-\mathrm{HT}_{3} \mathrm{AT}$

$5-\mathrm{HT}_{3} \mathrm{~B}$

$5-\mathrm{HT}_{3} \mathrm{BR} 1$

$5-\mathrm{HT}_{3} \mathrm{BR} 2$

$5-\mathrm{HT}_{3} \mathrm{C}$

$5-\mathrm{HT}_{3} \mathrm{D}$

$5-\mathrm{HT}_{3} \mathrm{E}$

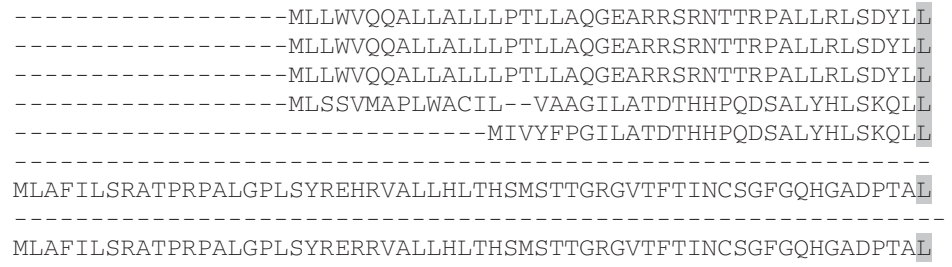

Loop D

TN--YRKGVRPVRDWRKPTTVSIDVIVYAILNVDEKNQVLTTY IWYRQYWTDEFLQWNPE TN--YRKGVRPVRDWRKPTTVS IDVIVYAILNVDEKNQVLTTY IWYRQYWTDEFLQWNPE TN--YRKGVRPVRDWRKPTTVS IDVIVYAILNVDEKNQVLTTY IWYRQYWTDEFLQWNPE QK--YHKEVRPVYNWTKATTVYLDLFVHAILDVDAENQILKTSVWYQEVWNDEFLSWNSS QK--YHKEVRPVYNWTKATTVYLDLFVHAILDVDAENQILKTSVWYQEVWNDEFLSWNSS NSVFNRKPFRPVTNISVPTQVNISFAMSAILDV-----.-----VWDNPFISWNPE NSVFNRKPFRPVTNISVLTQVNISFAMSAILDVNEQLHLLSSFLWLEMVWDNPFISWNPE

Loop A

Loop E

DFDNITKLSIPTDSIWVPDILINEFVDVGKSPNIPYVYIRHQGEVQNYKPLQVVTACSLD DFDNITKLSIPTDSIWVPDILINEFVDVGKS PNI PYVYVHHRGEVQNYKPLQLVTACSLD DFDNITKLSIPTDSIWVPDILINEFVDVGKSPNI PYVYIRHQGEVQNYKPLQVVTACSLD MFDEIREISLPLSAIWAPDIIINEFVDIERYPDLPYVYVNSSGTIENYKPIQVVSACSLE MFDEIREISLPLSAIWAPDI INEFVDIERYPDLPYVYVNSSGTIENYKPIQVVSACSLE MFDEIREISLPLSAIWAPDIIINEFVDIERYPDLPYVYVNSSGTIENYKPIQVVSACSLE ECEGITKMSMAAKNLWLPDIFI IELMDVDKTPKGLTAYVSNEGRIRYKKPMKVDSICNLD ECEGITKMSMAAKNLWLPDIFI IELMDVDKTPKGLTAYVSNEGRIRYKKPMKVDSICNLD

Loop B

Loop F

IYNFPFDVQNCSLTFTSWLHTIQDINISLWRLPEKVKS-DRSVFMNQGEWELLGVLPYFR IYNFPFDVQNCSLTFTSWLHTIQDINISLWRLPEKVKS-DRSVFMNQGEWELLGVLPYFR IYNFPFDVQNCSLTFTSWLHTSGHPPAAPLLCG-QPAT-AQHLPHGHGHRGLLPAPQQWR TYAFPFDVQNCSLTFKSILHTVEDVDLAFLRSPEDIQH-DKKAFLNDSEWELLSVSSTYTYAFPFDVQNCSLTFKSILHTVEDVDLAFLRSPEDIQH-DKKAFLNDSEWELLSVSSTYTYAFPFDVQNCSLTFKSILHTVEDVDLAFLRSPEDIQH-DKKAFLNDSEWELLSVSSTYIFYFPFDQQNCTLTFSSFLYTVDSMLLDMEKEVWEITDASRNILQTHGEWELLGLSKATIFYFPFDQQNCTLTFSSFLYTVDSMLLDMEKEVWEITDASRNILQTHGEWELLGLSKAT-

Loop C

M1

EFSMESSNYYAEMKFYVVIRRRPLFYVVSLLLPSIFLMVMDIVGFYLPPNSGERVSFKIT EFSMESSNYYAEMKFYVVIRRRPLFYVVSLLLPSIFLMVMDIVGFYLPPNSGERVSFKIT EG---LFQDYTPPGLLGLPDHRF-

SILQSSAGGFAQIQFNVVMRRHPLVYVVSLLIPSIFLMLVDLGSFYLPPNCRARIVFKTS SILQSSAGGFAQIQFNVVMRRHPLVYVVSLLIPSIFLMLVDLGSFYLPPNCRARIVFKTS SILQSSAGGFAQIQFNVVMRRHPLVYVVSLLIPSIFLMLVDLGSFYLPPNCRARIVFKTS AKLSRGGNLYDQIVFYVAIRRRPSLYVINLLVPSGFLVAIDALSFYLPVKSGNRVPFKIT DRAERSPSALSPTQVAIRHRCRPSPYVVNFLVPSGILIAIDALSFYLPPESGNCAPFKMT AKLSRGGNLYDRIVFYVAIRRRPSLYVINLLVPSGFLVAIDALSFYLPVKSGNRVPFKIT

\section{M2} KAPPGSRAQSGEKPAPSHLLHVSLASALGCTG

$\overline{\text { LLGYSVFLIIVSDTLPATAIGTPLIGVYFVVCMALLVISLAETIFIVRLVH }-K Q D L Q Q P}$ LLLGYSVFLIIVSDTLPATAIGTPLIGVYFVVCMALLVISLAETIF IVRLVH-KQDLQQP

$5-\mathrm{HT}_{3} \mathrm{AL}$

$5-\mathrm{HT}_{3} \mathrm{AT}$

$5-\mathrm{HT}_{3} \mathrm{~B}$

$5-\mathrm{HT}_{3} \mathrm{BR} 1$

$5-\mathrm{HT}_{3} \mathrm{BR} 2$

$5-\mathrm{HT}_{3} \mathrm{C}$

$5-\mathrm{HT}_{3} \mathrm{D}$

$5-\mathrm{HT}_{3} \mathrm{E}$

VLVGYTVFRVNMSNQVPRSVGSTPLIGHFFTICMAFLVLSLAKSIVLVKFLHDEQRGGQE VLVGYTVFRVNMSNQVPRSVGSTPLIGHFFTICMAFLVLSLAKS IVLVKFLHDEQRGGQE VLVGYTVFRVNMSNQVPRSVGSTPLIGHFFTICMAFLVLSLAKSIVLVKFLHDEQRGGQE LLLGYNVFLLMMSDLLPTS - -GTPLIGVYFALCLSLMVGSLLETIF ITHLLHVATTQPPP VLLGYSVFLLMMNDLLPAT--STSKRGVYFALCLSLMVGSLLETIFITHLLHVATTQPLP LLLGYNVFLLMMSDLLPTS--GTPLIGVYFALCLSLMVGSLLETIFITHLLHVATTQPPP

SHASLVRPHPSR

Fig. 2. (Cont.) 


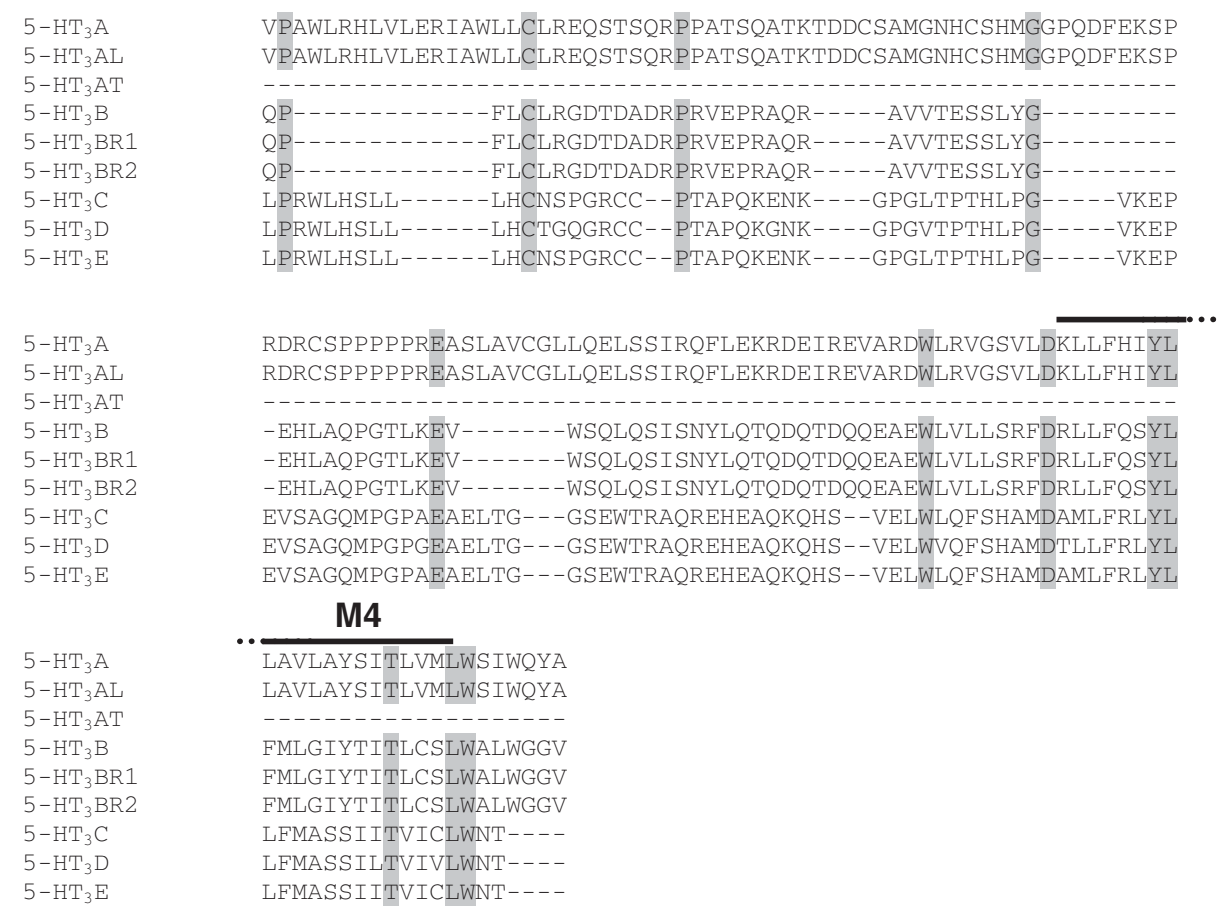

Fig. 2. Alignment of human $5-\mathrm{HT}_{3}$ receptor subunits. The binding loops $(\mathrm{A}-\mathrm{F})$ and transmembrane (M1-M4) regions are highlighted by horizontal lines above the text. Conserved residues are highlighted with a grey background. The human alternative long (5- $\left.\mathrm{HT}_{3} \mathrm{AL}\right)$, truncated $\left(5-\mathrm{HT}_{3} \mathrm{AT}\right)$, Brain1 $\left(5-\mathrm{HT}_{3} \mathrm{BR} 1\right)$ and Brain2 (5- $\mathrm{HT}_{3} \mathrm{BR} 2$ ) forms are shown. The boxes show the additional residues found in 5-HT $\mathrm{AL}_{3}(32$ amino acids) and $5-\mathrm{HT}_{3} \mathrm{D}\left(12\right.$ amino acids) variants. Accession numbers for the alignment are as follows : 5 - $\mathrm{HT}_{3 \mathrm{~A}}$ P46098, 5- $\mathrm{HT}_{3 \mathrm{~B}} \mathrm{O} 95264$ and 5-HT $3 \mathrm{C}$ Q6V706. 5-HT $3 \mathrm{D}$ and 5HT $3 \mathrm{E}$ were taken from Niesler et al. (2003). 5-HT $\mathrm{H}_{3} \mathrm{AL}$ and 5-HT $\mathrm{HT}_{3} \mathrm{AT}$ were taken from Bruss et al. (2000). 5- $\mathrm{HT}_{3} \mathrm{BR} 1$ and 5-HT ${ }_{3} \mathrm{BR} 2$ were taken from Tzvetkov et al. (2007).

since this time other AChBP structures have been reported (e.g. Celie et al. 2004, 2005b; Hansen \& Taylor, 2007; Hibbs et al. 2009). The similarity between AChBP and the ECD of Cys-loop receptors was confirmed when the structures of an nACh subunit monomer and subsequently homologous prokaryotic receptors were determined (Bocquet et al. 2009; Dellisanti et al. 2007; Hilf \& Dutzler, 2008; Nury et al. 2009). With this similarity established, we can be more confident that studies that utilized the AChBP structure to make predictions within Cysloop receptors were broadly correct. A review of prokaryotic receptors can be found in Corringer et al. (2010).

\subsection{The ligand-binding site}

Early biochemical and labelling studies indicated that Cys-loop receptor ligand-binding sites were constituted by three non-contiguous regions from the ECDs of two contributing subunits. With the advent of the AChBP crystal structure, it was confirmed that the binding site was at the interface between two adjacent subunits (Brejc et al. 2001; Celie et al. 2004, 2005a, 2005b). The two adjacent subunits are termed the principal and complementary subunits, and the binding site is formed by three peptide loops (loops A-C) from the principal subunit, and three $\beta$-sheets 
(loops D-F) from the complementary subunit; as this terminology was introduced before crystallographic studies revealed the secondary structure, these regions are not all 'loops' (Fig. 3).

The exact location of the loop region varies subtly with different subunits of different receptors; the locations that we have shown in Fig. 3 are therefore only approximate. Only one or a few residues within each loop may face into the binding pocket, with residues in the remainder of the loop probably maintaining the structure of the pocket and/or participating in the conformational changes that result in channel opening. Evidence from AChBP structures (discussed later in section 7.5) suggests that binding of different ligands results in different movements of the binding pocket; the ECD generally contracts around agonists, but adopts a more open structure with antagonists. It has been known for some time that antagonists and agonists may interact with different binding pocket residues, and one ligand may interact with more or less residues than another (e.g. a large nAChR antagonist such as $\alpha$-bungarotoxin ( $\alpha$-BTX) interacts with a much larger repertoire of residues than a small antagonist such as methyllycaconitine). What is perhaps more surprising is that agonists do not need to interact with the same residues to activate the receptor. For example, 5-HT forms a critical hydrogen bond with Glu129 in the $5-\mathrm{HT}_{3} \mathrm{R}$, but 5-FT, which still activates the receptor (albeit as a partial agonist), does not appear to interact at all with this residue (Bower et al. 2008).

For the majority of Cys-loop receptors, at least two binding sites are required for channel activation, and at muscle nAChRs, the principal subunits at both these sites are the $\alpha 1$ subtype; for some neuronal receptors, it appears that the two principal subunits differ within a single receptor, for instance $\alpha 4$ and $\alpha 6$ (Champtiaux et al. 2003; Rayes et al. 2009). Questions about cooperative binding are often finessed with the statement that the open state of the channel is more likely to be associated with the presence of at least two bound agonists, although certain mutant receptors have Hill slopes near unity, allowing for the possibility of opening with just a single bound agonist. In some mutant receptors that are highly agonist-sensitive, there is also constitutive activation in the total absence of agonist, as though the open state is rather more stable than normal (e.g. Bhattacharya et al. 2004).

Cys-loop receptor-binding sites all contain a number of aromatic residues (Table 1). For many of the Cys-loop receptors, a cation $-\pi$ interaction has been described between the natural ligand and one of these aromatic residues. This type of interaction has been observed in a variety of proteins using high-resolution structural data, but for Cys-loop receptors cation- $\pi$ interactions have only been identified using unnatural amino acid mutagenesis (Dougherty, 2008). For this technique, a series of electron-withdrawing or electron-donating groups are substituted onto the side chains of aromatic residues, subtly altering the energy of the cation $-\pi$ interaction. If the $\mathrm{EC}_{50}$ varies monotonically with the calculated strength of the interaction, this is evidence for the presence of a cation $-\pi$ interaction. In all Cys-loop receptors examined to date, when a cation- $\pi$ interaction is found, the ligand interacts with only one aromatic side chain in the binding pocket; in some other proteins, the efficient stabilization of this bond relies upon interactions with several aromatic rings, and the optimal orientation of the cationic centre is normal to the planes passing through the centroids of these rings (Schärer et al. 2005).

Different aromatic side chains (Trp, Phe or Tyr) make a cation- $\pi$ interaction in different Cysloop receptors. Each of these is located in one of the three loops on the principal subunit (Table 1); as yet, no cation $-\pi$ interactions have been found in the complementary subunit. In the $5-\mathrm{HT}_{3} \mathrm{R}$, the contributing residue is a loop B $\operatorname{Trp}$ (Beene et al. 2002, 2004), while in the MOD-1 receptor (also activated by 5-HT) it is a Trp in loop C (W226; Mu et al. 2003). Therefore, even in receptors activated by the same ligand, the residue involved in the cation $-\pi$ interaction can differ. 


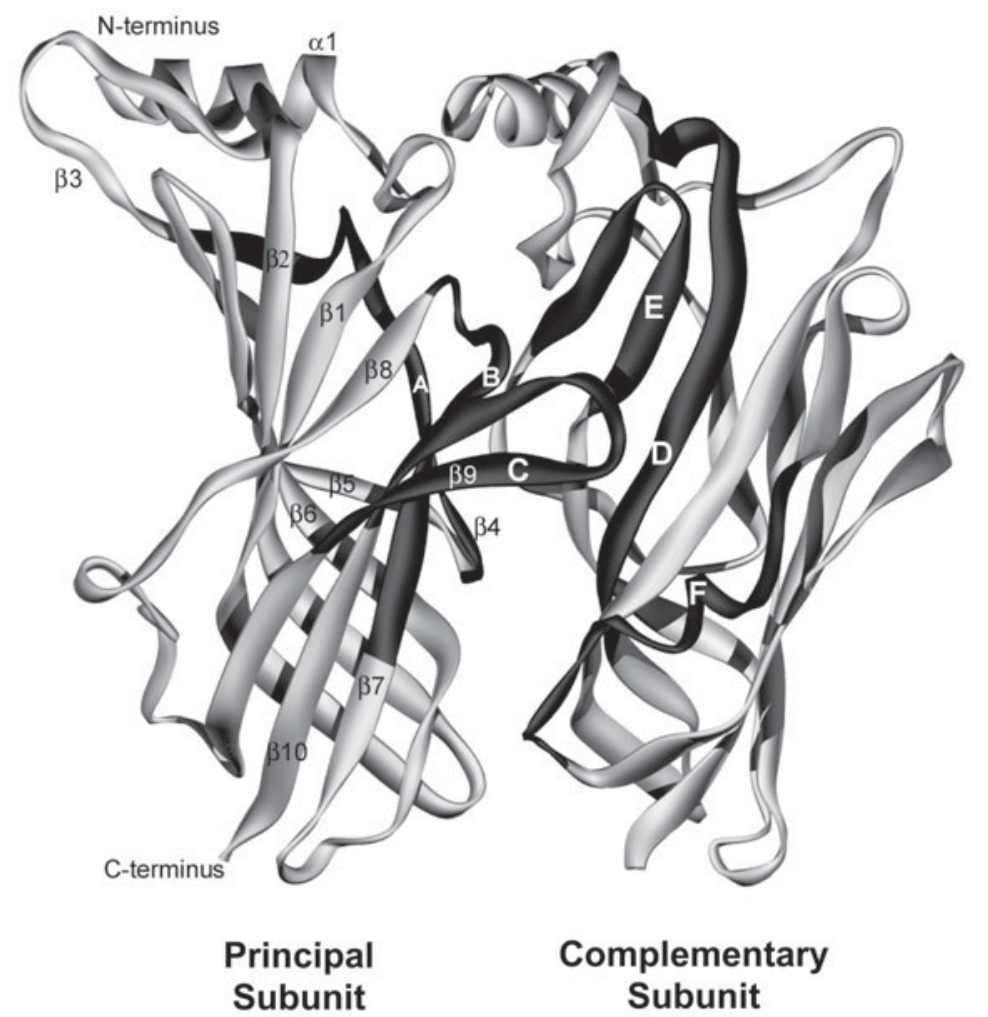
$5-\mathrm{HT}_{3} \mathrm{~A}$
$\mathrm{AChBP}$

$5-\mathrm{HT}_{3} \mathrm{~A}$ AChBP

$5-\mathrm{HT}_{3} \mathrm{~A}$ AChBP

$5-\mathrm{HT}_{3} \mathrm{~A}$
$\mathrm{AChBP}$

Loop D

Loop A

LNVDEKNQVLTTYIWYRQYWTDEFLQWTPEDFDNVTKLSIPTDSIWVPDILINEFVDVGK 135 LEVNEITNEVDVVFWQQTTWSDRTLAWNSSH--SPDQVSVPISSLWVPDLAAYNAISKP- 95

$\beta 2$

$\beta 3$

$\beta 4$

\section{Loop E}

Loop B

SP-NIPYVYVHHRGEVQNYKPLQLVTACSLDIYNFPFDVQNCSLTFTSWLHTIQDINITL 194 EVLTPQLARVVSDGEVLYMP SIRQRFSCDVSGVDTESG-ATCRIKIGSWTHHSREISVDP 154
$\beta 5$
$\beta 5^{\prime}$
$\beta 6$
$\beta 6^{\prime}$
$\beta 7$
$\beta 8$

\section{Loop F}

\section{Loop C}

WRSPEEVRSDKSIFINQGEWELLEVFPQFKEFS-IDISNS-YAEMKFYVIIRRRPLFYAV 252 TT--E-NSDDSEYFSQYSRFEILDVTQKKNSVTYSCCPEA-YEDVEVSLNFRKKGRSEIL 210

Fig. 3. AChBP, an analogous protein to the ECD of Cys-loop receptors. AChBP contains five subunits, but for clarity only two of these are shown. The binding loops and $\beta$-sheets are shown, the positions of which are taken from Brejc et al. (2001). The same binding loops and $\beta$-sheets are labelled in the linear amino-acid sequence below. 
Table 1. Aromatic residues in the binding sites of different Cys-loop receptors. Residues that contribute to cation- $\pi$ interactions are shown in bold. ${ }^{1,3}$ Beene et al. (2002), ${ }^{2}$ Xiu et al. (2009), ${ }^{4}$ Mu et al. (2003), ${ }^{5}$ Padgett et al. (2007), ${ }^{6}$ Lummis et al. (2005a), ${ }^{7}$ Pless et al. (2008). See Dougherty (2008) for further information. Note that loop $D$ is in the complementary face, and residues from this face have not been found to form cation $-\pi$ interactions to date

\begin{tabular}{lllllll}
\hline \hline Receptor & Ligand & Loop A & Loop B & \multicolumn{2}{c}{ Loop C } & Loop D \\
\hline nACh $(\alpha 1 \beta \gamma \delta)^{1}$ & ACh & Y93 & W149 & Y190 & Y198 & W55 \\
nACh $(\alpha 4 \beta 2)^{2}$ & ACh, Nicotine & Y98 & W154 & Y195 & Y202 & W55 \\
5-HT 3 & 5-HT & E129 & W183 & F226 & Y234 & W90 \\
MOD-1 $^{4}$ & 5-HT & C120 & Y180 & Y221 & W226 & F83 \\
GABA $_{A}^{5}$ & GABA & Y97 & Y157 & F200 & Y205 & F65 \\
GABA $_{C}^{6}$ & GABA & F138 & Y198 & Y241 & Y247 & Y102 \\
Gly $^{7}$ & Gly & F99 & F159 & Y202 & F207 & F63 \\
\hline \hline
\end{tabular}

Similarly in the $\mathrm{GABA}_{C}$ receptor, GABA has a cation- $\pi$ interaction with a loop B Tyr residue, but in the $\mathrm{GABA}_{\mathrm{A}}$ receptor, GABA has a cation- $\pi$ interaction at a Tyr on loop A. Several exogenous or synthetic agonists can also make cation $-\pi$ interactions (e.g. epibatidine; Cashin et al. 2005) but it is not essential; for example, nicotine can make a cation- $\pi$ interaction at the neuronal $\alpha 4 \beta 2 \mathrm{nAChR}$, but does not make a cation $-\pi$ interaction at the muscle $\mathrm{nAChR}$ (Beene et al. 2002; Xiu et al. 2009). These data provide an explanation for the low potency of nicotine at muscle nAChRs (and an understanding of why smoking does not cause severe muscle contractions), and also demonstrates the importance of understanding the molecular interactions when designing receptor-specific drugs. These data also highlight the problem that even with good structural information, docking a ligand into a protein may not always be accurate, and experimental data are essential to allow the correct solution to be selected from possible options.

\subsection{Ligand binding; in silico predictions from the $5-\mathrm{HT}_{3} \mathrm{R}$}

In silico predictions of ligand binding require either a high-resolution structure or a homology model, and the template used for the latter will determine its accuracy. To show how differing starting templates can introduce conformational variability, Fig. 4 overlays two 5- $\mathrm{HT}_{3}$ homology models that were created using similar AChBP structures containing the same bound ligand (HEPES; PDB ID's 1I9B and 1UX2). The overlay shows that the backbones closely mirror each other, but there are considerable differences in the orientations of side chains. Other starting templates that contain different bound ligands produce further variation, and if we use these for in silico docking, the positions of the side chains can have a significant impact on the final orientation of the ligand. Nevertheless, homology models have been produced for many receptors, and a range of ligands docked into their binding sites (e.g. Abdel-Halim et al. 2008; Cromer et al. 2002; Le Novere et al. 2002; Maksay et al. 2003; Reeves et al. 2003; Schapira et al. 2002; Trudell \& Bertaccini, 2004; Yan \& White, 2005). The ability of 5- $\mathrm{HT}_{3} \mathrm{Rs}$ to form homomeric receptors means that they are a relatively simple system for molecular modelling, and they have the considerable advantage that the experimental determination of the effects of amino acid substitutions on the properties of the receptor is straightforward. In the following section, this receptor is used as a model system to illustrate some of the pros and cons of in silico techniques. 


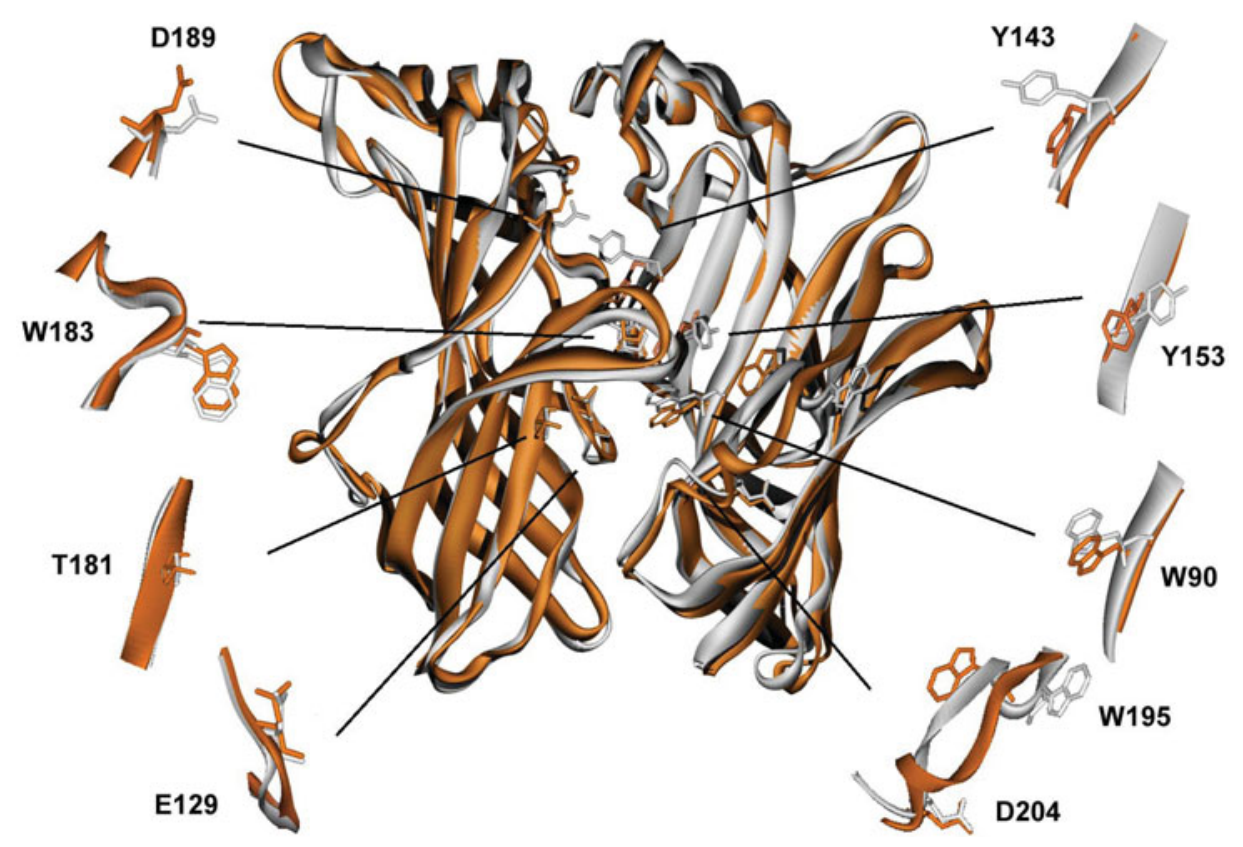

Fig. 4. An overlay of two 5- $\mathrm{HT}_{3}$ receptor homology models that were based on HEPES bound AChBP structures (PDB ID: 1I9B white and 1UX2 orange). Some residues that have been shown to be important for granisetron (a selective 5- $\mathrm{HT}_{3}$ antagonist) binding are highlighted and emphasize that some regions e.g. close to W195, have large differences in the orientation of their side chains. The relative positions of the models were compiled by Swiss-PdbViewer 'magic fit' using loop B as a reference point.

In silico docking of ligands can be performed using a variety of software tools. One of the most widely used and well regarded is GOLD (The Cambridge Crystallographic Data Centre, Cambridge UK), which places a ligand into the protein and then improves the fit by iteratively moving the ligand into the most energetically favourable orientation (Olsen et al. 2004a). To explore its accuracy, we determined whether GOLD could adequately locate binding sites and correctly position ligands in them by removing ligands from their original protein structures and re-docking them. Figure 5 shows the 10 predicted ligand orientations for nicotine and carbamylcholine in their original AChBP crystal structures, and in two other randomly selected structures. In each instance, the software correctly located the ligand within the receptor, although there are some subtle differences in their precise orientations.

Granisetron is a selective, competitive antagonist of $5-\mathrm{HT}_{3} \mathrm{Rs}$. Nuclear magnetic resonance (NMR) and crystallography studies of granisetron show that the azabicyclic of granisetron adopts a boat-chair configuration, and the carbonyl linker is relatively immobile (i.e. rigid), with a dihedral angle of $180^{\circ}$ (Fludzinski et al. 1987; Roe \& Kuntz, 1995; Schmidt \& Peroutka, 1989; Vernakar et al. 2010). Using this structure, we docked granisetron into a range of $5-\mathrm{HT}_{3} \mathrm{R}$ homology models, the templates of which were the 18 currently available AChBP, nACh and prokaryotic receptor structures (Tables 2 and 3). We have used a flexible ligand (non-constrained bond angles) and a rigid ligand (constrained bond angles), and the tables show the additional variability that is introduced by altering the flexibility of the ligand. A comparison of the results shows that granisetron is located in broadly similar locations in the binding pockets, although the predicted orientations differ (Fig. 6). Flexible (Table 2) and rigid (Table 3) ligand docking 
(A)

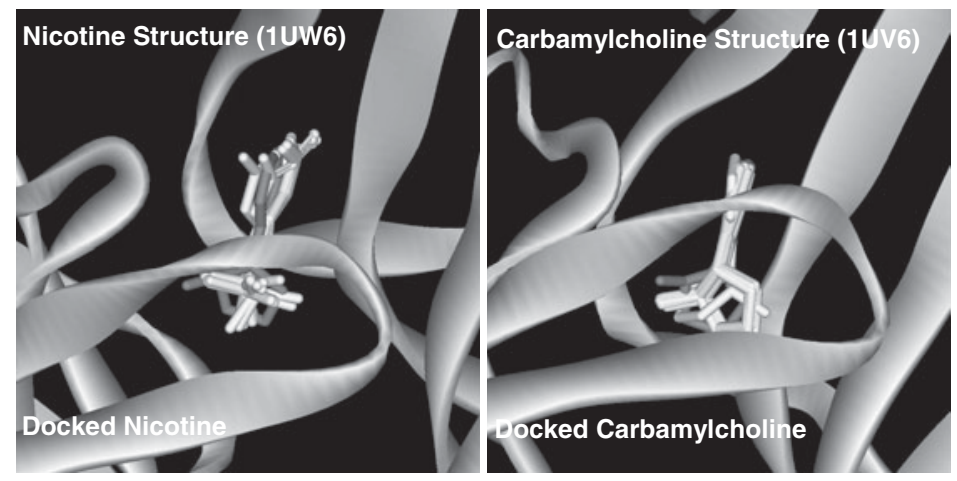

(B)
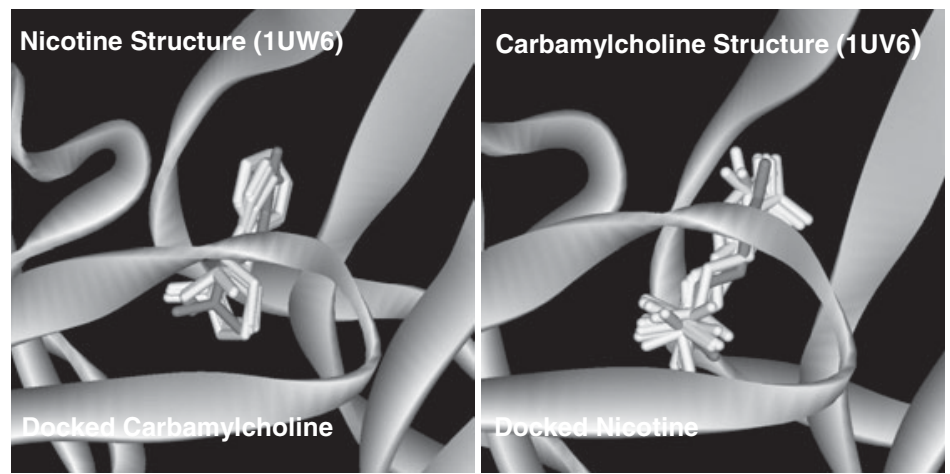

(C)
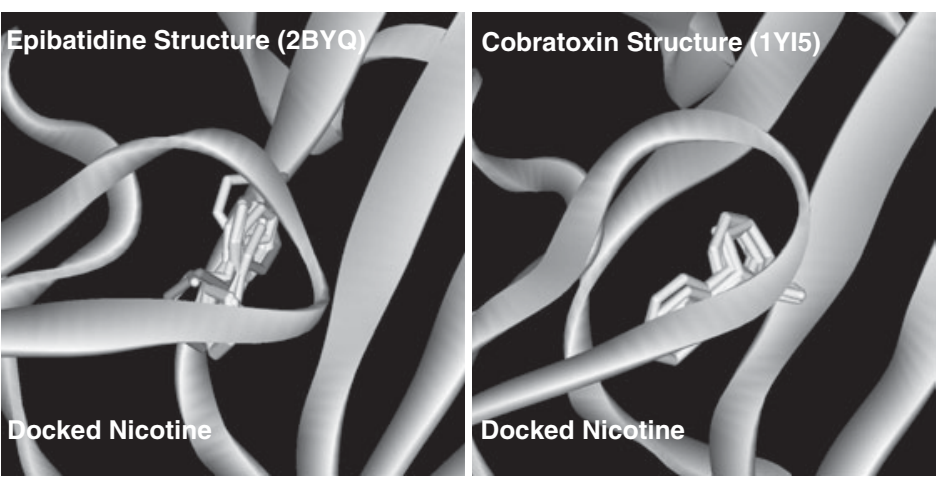

Fig. 5. A test for the accuracy of computational ligand docking. (A) Nicotine and carbamylcholine re-docked into their respective AChBP structures. (B) Nicotine docked into the carbamylcholine structure and vice versa. (C) Nicotine docked into two other AChBP structures. In each panel, the original ligand molecule is shown in grey and 10 docking solutions are shown in white; the ligands are clearly positioned on top of one another within the binding site.

generated eight and five categories of potential ligand orientations, respectively. Rigid docking increased the incidence of granisetron being placed outside the binding site (described as others); docking errors may be responsible, although some locations may represent local energy minima within the binding and unbinding routes, as previously suggested (Joshi et al. 2006; Maksay et al. 2003; Thompson et al. 2006a; Zhang et al. 2006). 
Table 2. Flexible ligand docking of granisetron into the $5-H T_{3}$ receptor-binding site produces docked clusters that can be categorized into one of eight groups (A1-E). Docking solutions that place granisetron outside the binding site are described as others. The data were created using the boat-chair configuration of granisetron docked into a series of $5-H_{3}$ homology models that were generated from the 18 currently available PDB templates that show homology to Cys-loop receptors. The protein sequence of the murine 5-HT receptor (accession number: Q6J1J7) was co-aligned with each of the template sequences using FUGUE, which takes into account secondary structures (Shi et al. 2001). Using Modeller 6v2, five homology models were generated from each PDB template (Sali \& Blundell, 1993), and the best model selected using Ramachandran plot analysis. The protonated form of granisetron was constructed in Chem3D Ultra 7.0 (CambridgeSoft, Cambridge, UK) based on the crystal structure of a related indazole carboxamide (Cambridge Structural Database; reference code FIZXUH) and docked with GOLD v3.0 (The Cambridge Crystallographic Data Centre, Cambridge, UK), into a binding site that was defined as being within $20 \AA$ of the $\alpha$-carbon of W183. To dock ligands, 10 genetic algorithm runs were carried out for each homology model, with a population size of 50 and the maximum number of generations set to 27000 . For each homology model, the 10 docking solutions were categorized according to the ligand orientation, and the number of solutions in each category are shown (see Fig. 6 legend for descriptions)

\begin{tabular}{|c|c|c|c|c|c|c|c|c|c|c|c|}
\hline \multicolumn{3}{|c|}{$\begin{array}{l}\text { Starting Template for } \\
\text { the } 5-\mathrm{HT}_{3} \mathrm{R} \text { homology model }\end{array}$} & \multicolumn{9}{|c|}{$\begin{array}{l}\text { Number of ligand orientations in each } \\
5-\mathrm{HT}_{3} \mathrm{R} \text { homology model }\end{array}$} \\
\hline Protein & Ligand type & PDB & A1 & $\mathrm{A} 2$ & B1 & B2 & $\mathrm{C} 1$ & $\mathrm{C} 2$ & $\mathrm{D}$ & $\mathrm{E}$ & Other \\
\hline Aplysia AChBP & - & $2 \mathrm{BYN}$ & & 3 & & & & & 7 & & \\
\hline Aplysia AChBP & HEPES & 2BR7 & & 7 & & & & & & 3 & \\
\hline Limnaea AChBP & HEPES & 1I9B & & 9 & & & & & & & 1 \\
\hline Limnaea AChBP & HEPES & 1UX2 & & 1 & & 6 & 2 & 1 & & & \\
\hline Aplysia AChBP & Epibatidine & 2BYQ & 3 & 4 & & & 1 & & & 1 & 1 \\
\hline Limnaea AChBP & Carbomylcholine & 1UV6 & & & 1 & & & 1 & & 8 & \\
\hline Limnaea AChBP & Nicotine & 1UW6 & & 10 & & & & & & & \\
\hline Aplysia AChBP & Methyllcaconitine & 2BYR & & & & & & & 1 & 7 & 2 \\
\hline Aplysia AChBP & Lobeline & 2BYS & 5 & 4 & & & & & & 1 & \\
\hline $\begin{array}{l}\text { Bulinus truncatus } \\
\text { AChBP }\end{array}$ & CAPS & 2BJO & & & & & & & & 10 & \\
\hline $\begin{array}{l}\text { Torpedo marmorata } \\
\mathrm{nAChR}\end{array}$ & - & 2BG9 & 3 & 1 & & 1 & & & & & 5 \\
\hline Limnaea AChBP & $\alpha$-Cobratoxin & 1 YI5 & & 4 & & & & & & 5 & 1 \\
\hline Aplysia AChBP & $\alpha$-Cobratoxin & 2BYP & & & 3 & 7 & & & & & \\
\hline Aplysia AChBP & $\alpha$-Conotoxin & 2C9T & & & 2 & 8 & & & & & \\
\hline Erwinia LGIC & - & 2VL0 & & 2 & & 3 & & 5 & & & \\
\hline Gleobacter LGIC & - & 3ЕAM & & & & & & & & & 10 \\
\hline Aplysia AChBP & Cocaine & 2PGZ & & & 10 & & & & & & \\
\hline Aplysia AChBP & Tropisetron & $2 \mathrm{WNC}$ & & 1 & 2 & 1 & 1 & 4 & & & 1 \\
\hline \multicolumn{3}{|c|}{ Total number of orientations in each category } & 11 & 46 & 18 & 26 & 4 & 11 & 8 & 35 & 21 \\
\hline
\end{tabular}

An alternative method for orientating a ligand uses a protein in which a structurally similar ligand with a common pharmacophore has been co-crystallized (Fig. 7). To predict interacting amino acids, the new ligand can be pasted into the model. This method can result in steric clashes between the ligand and receptor, but these can be minimized with the software. It must be stressed, however, that all these in silico methods only estimate the possible orientations of amino-acid side chains and docked ligands. They do nevertheless provide testable hypotheses that can be validated by experimentation. 
Table 3. Rigid ligand docking of granisetron into the 5-HT 3 receptor binding site produces docked clusters which can be categorized into one of five groups. Methods used can be found in the legend of Table 2

\begin{tabular}{|c|c|c|c|c|c|c|c|c|}
\hline \multicolumn{3}{|c|}{$\begin{array}{l}\text { Starting template for the } 5-\mathrm{HT}_{3} \mathrm{R} \\
\text { homology model }\end{array}$} & \multicolumn{6}{|c|}{$\begin{array}{l}\text { Number of ligand orientations in each } \\
5-\mathrm{HT}_{3} \mathrm{R} \text { homology model }\end{array}$} \\
\hline Protein & Ligand Type & PDB & A1 & $\mathrm{A} 2$ & B2 & $\mathrm{C} 1$ & $\mathrm{C} 2$ & Other \\
\hline Aplysia AChBP & - & $2 \mathrm{BYN}$ & & & 10 & & & \\
\hline Aplysia AChBP & HEPES & 2BR7 & 5 & 2 & & & & 3 \\
\hline Limnaea AChBP & HEPES & 1I9B & 5 & 2 & & & & 3 \\
\hline Limnaea AChBP & HEPES & 1UX2 & & 4 & 2 & & 4 & \\
\hline Aplysia AChBP & Epibatidine & 2BYQ & 5 & & 5 & & & \\
\hline Limnaea AChBP & Carbomylcholine & $1 \mathrm{UV6}$ & & & & 8 & 2 & \\
\hline Limnaea AChBP & Nicotine & 1UW6 & & 3 & 1 & & & 6 \\
\hline Aplysia AChBP & Methyllcaconitine & 2BYR & & & & 7 & & 3 \\
\hline Aplysia AChBP & Lobeline & 2BYS & 1 & 1 & 8 & & & \\
\hline $\begin{array}{l}\text { B. truncatus } \\
\text { AChBP }\end{array}$ & CAPS & $2 \mathrm{BJO}$ & 3 & & & & & 7 \\
\hline $\begin{array}{l}\text { T. marmorata } \\
\mathrm{nAChR}\end{array}$ & - & 2BG9 & & 1 & & & & 9 \\
\hline Limnaea AChBP & $\alpha$-Cobratoxin & 1YI5 & 1 & 2 & 1 & & & 6 \\
\hline Aplysia AChBP & $\alpha$-Cobratoxin & 2BYP & & 4 & & & 6 & \\
\hline Aplysia AChBP & $\alpha$-Conotoxin & $2 \mathrm{C} 9 \mathrm{~T}$ & & & 6 & & & 4 \\
\hline Erwinia LGIC & - & 2VL0 & & & & & & 10 \\
\hline Gleobacter LGIC & - & 3EAM & & & & & & 10 \\
\hline Aplysia AChBP & Cocaine & 2PGZ & & & & 10 & & \\
\hline Aplysia AChBP & Tropisetron & $2 \mathrm{WNC}$ & & 5 & 5 & & & \\
\hline \multicolumn{3}{|c|}{ Total number of orientation in each category } & 20 & 24 & 38 & 25 & 12 & 61 \\
\hline
\end{tabular}

\subsubsection{Ligand binding; experimental evidence for the $5-\mathrm{HT}_{3} \mathrm{R}$ in silico predictions}

The two methods (flexible and rigid docking) produced in total eight distinct categories (or clusters) of ligand orientations (see Fig. 6), with, for example, 26 and 38 poses respectively in the orientation B2. This places granisetron with the azabicyclic rings between W183 and Y234, and the indazole ring towards loop E. Orientation A2 is the total most common (46 and 24 poses, respectively) and has more interactions with residues that have been identified as important in the 5- $\mathrm{HT}_{3} \mathrm{R}$ binding site (Joshi et al. 2006; Thompson et al. 2005). The orientation that is best supported by the experimental evidence, however, is A1, where the orientation of granisetron is reversed so that the indazole ring is located between W183 and Y234 with the azabicyclic ring orientated towards the transmembrane region, between residues E129 and W90. Double-mutant cycle analysis shows that the azabicyclic ring of granisetron is close to W90 and the indazole ring is orientated away from the membrane (Yan \& White, 2005), and this orientation is also supported by experimental evidence as described by both Joshi et al. (2006) and Thompson et al. (2005). In both orientations A1 and A2, there is an interaction with W183, a residue that is important for both agonist and antagonist binding (Beene et al. 2002; Spier \& Lummis, 2000), and with Y234, which also contributes to the binding site; substitutions of Y234 to Ala or Ser severely compromise granisetron binding, although Y234F mutants have similar binding affinities to wild-type receptors (Spier \& Lummis, 2000; Suryanarayanan et al. 2005). An Ala mutation at the adjacent $\mathrm{S} 233$ residue also abolishes binding, which may be due to its altering the 
(A1)

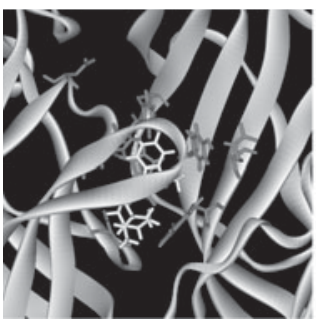

(A2)

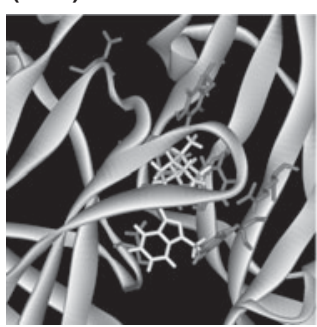

(B1)

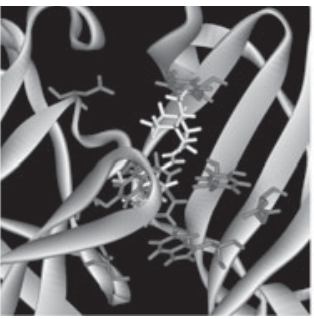

(B2)

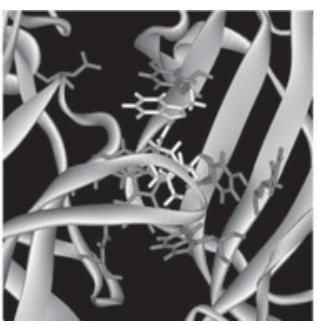

(C1)

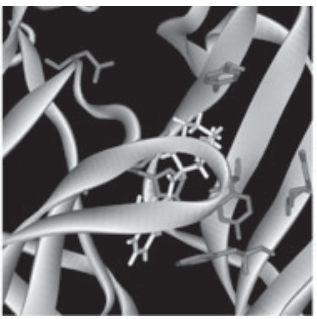

(C2)

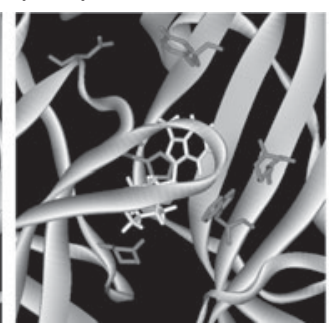

(D)

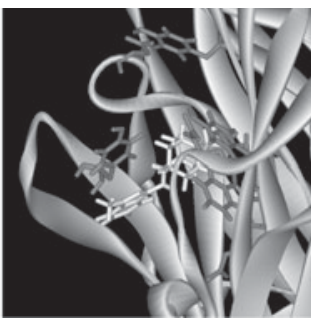

(E)

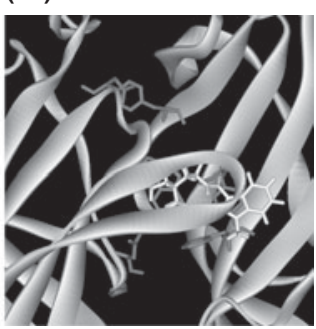

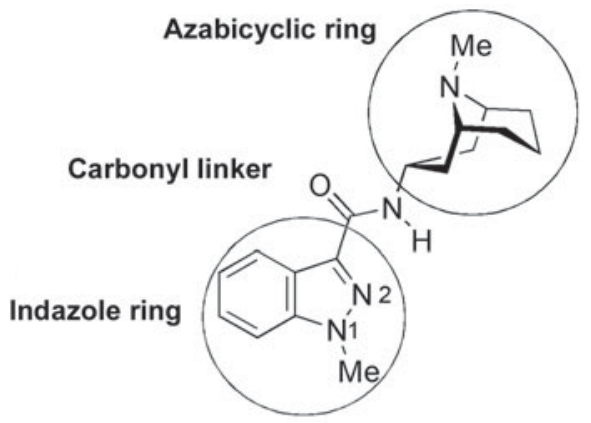

Granisetron

Fig. 6. Examples of the eight main categories of docked poses found in the 320 homology models generated for this study. Categories were largely based on the proximity of granisetron atoms to W183, and the orientation of the azabicyclic and indazole rings. The number of docked poses that fell into each of these categories can be seen in Tables 2 and 3. In brief, the descriptions of these clusters are as follows: (A1) Indazole ring close to W183 and the azabicyclic ring orientated towards the membrane. (A2) Same as A1, but with the azabicyclic and indazole rings reversed. (B1) Indazole ring close to W183 and the azabicyclic ring orientated towards Y143 in loop E. (B2) Same as B1, but with the azabicyclic and indazole rings reversed. (C1) Carbonyl linker close to W183 and the azabicyclic ring orientated away from the membrane. (C2) Same as (C1), but with the indazole ring orientated away from the membrane. (D) Either the azabicyclic or indazole rings close to W183 and the opposite end of the ligand orientated towards loop C. (E) Granisetron lies horizontally across the back of loop C. (Other) A number of unique positions located throughout the ECD.

location of the adjacent Y234 residue (Suryanarayanan et al. 2005). Mutation of both E129 and W90 strongly affect granisetron binding regardless of the amino acid used, showing that they are both essential; E129 hydrogen bonds with 5-HT, and may similarly interact with granisetron (Price et al. 2008; Spier \& Lummis, 2000; Sullivan et al. 2006; Yan et al. 1999), and W90 may 

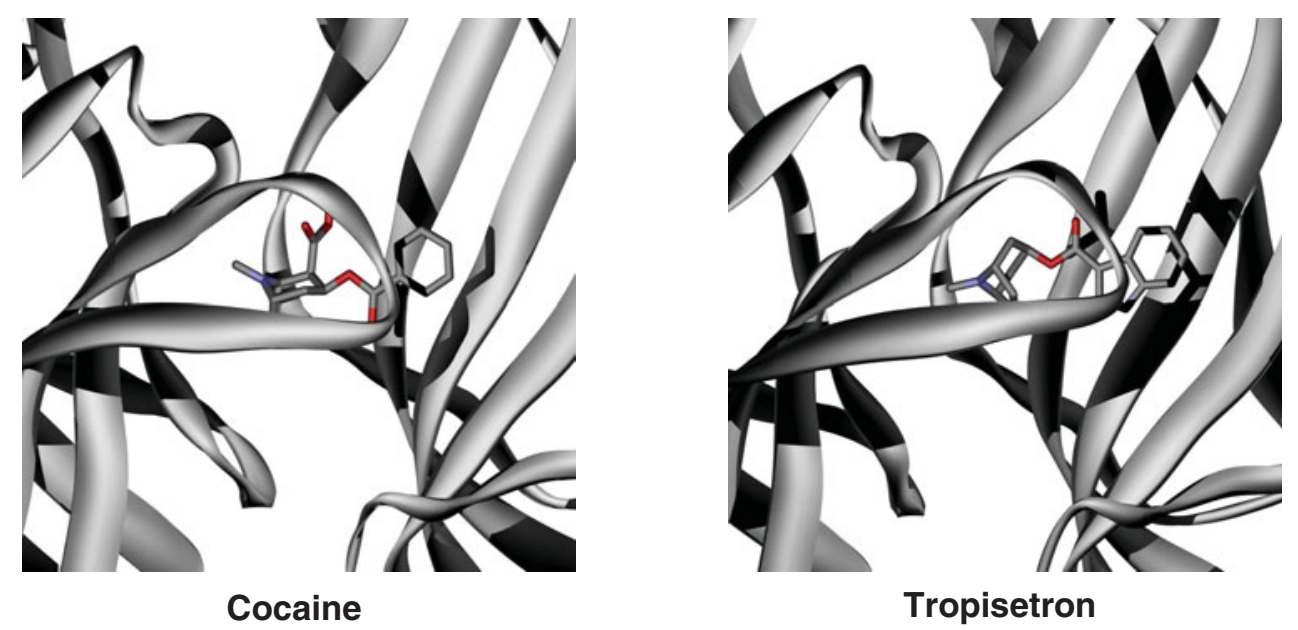

Fig. 7. AChBP crystal structures showing the orientations of cocaine (PDB ID: $2 \mathrm{PGZ}$ at $1.76 \AA$ ) and tropisetron (2WNC at $2 \cdot 2 \AA$ ). The orientations are most similar to category E described in Fig. 6.

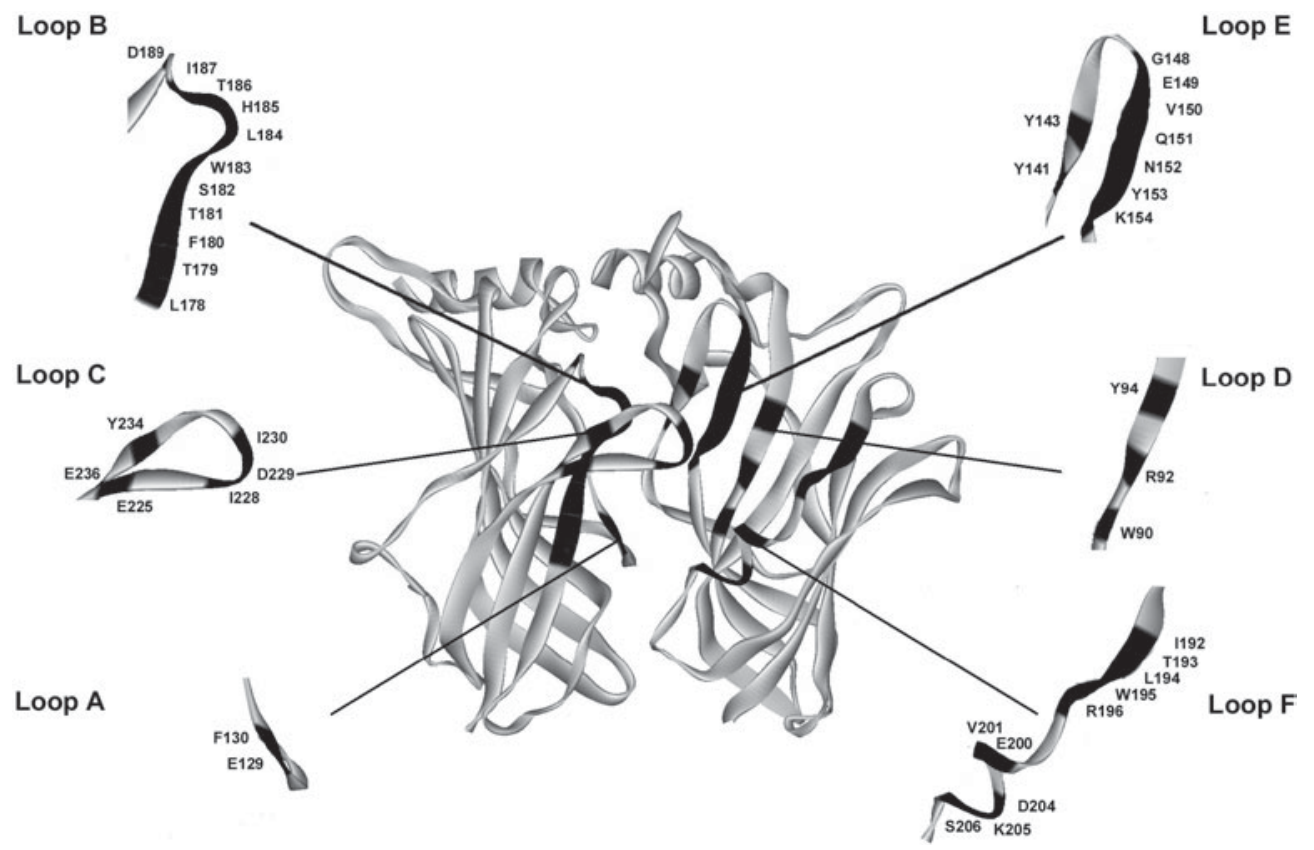

Fig. 8. Binding site substitutions that cause significant changes in the binding affinity of granisetron at the $5-\mathrm{HT}_{3}$ receptor. Residues have been superimposed upon a homology model of the $5-\mathrm{HT}_{3}$ receptor that was generated using 1I9B. The data were taken from Beene et al. (2004), Boess et al. (1997), Joshi et al. (2006), Price et al. (2008), Schreiter et al. (2003), Spier \& Lummis (2000), Thompson et al. (2005, 2006b, 2008), Venkataraman et al. (2002a, b), Yan et al. (1999), Yan \& White (2005) and Sullivan et al. (2006).

stabilize the structure of region by a T-type interaction with Tyr234 (Gallivan \& Dougherty, 1999).

Residues that have an impact on granisetron binding are shown in Fig. 8. These include a number of residues centred around W195 and D204 in loop F. Whether the residues in 
loop $\mathrm{F}$ are directly involved in ligand binding is difficult to determine from the homology models as this region is poorly resolved in the crystal structures, and some residues may interact with adjacent $\beta$-sheets rather than with the ligand itself (Spier \& Lummis, 2000; Thompson et al. 2006b). Loop E residues G148 and V150 have been shown to abolish ligand binding when mutated to Ala and there are also effects at residues L178, F180, Q188, D189, I190 and N191 in loop B (Joshi et al. 2006; Thompson et al. 2008; Venkataraman et al. 2002b). As many of these are at some distance from the binding site, and some are on opposite sides of $\beta$-sheets, it is unlikely that they directly interact with the ligand; their effects may be due to intramolecular interactions that are critical for the structure of the binding site (Thompson et al. 2006b, 2008). Some of these residues have also been implicated in the binding/unbinding pathway of the ligand, while others may contribute to the subunit interface, or be involved in the transduction of binding energy into channel opening Joshi et al. 2006; Thompson et al. 2006a).

\subsubsection{Ligand binding: summary}

Our docking results show a wide range of ligand orientations, highlighting the potential problem of developing theories based solely on in silico predictions. We can, however, use this information to design experiments to probe the accuracy of the predictions. For the 5- $\mathrm{HT}_{3} \mathrm{R}$, experimental data best support the predicted orientations of granisetron and 5-HT shown in Fig. 9, which are not the most common docking solutions, but are in general agreement with structure-activity relationships (Bower et al. 2008; Maksay et al. 2003; Reeves et al. 2003; Schmidt \& Peroutka, 1989). It must also be considered that it may be possible for ligands to adopt multiple orientations. For example, molecular dynamic studies examining GABA binding to the $G_{A B A} R$ show that GABA appears to 'flip' from one orientation to another during the simulation, although there is currently only experimental data to support one of the orientations (Melis et al.2008), and in silico predictions in the $5-\mathrm{HT}_{3} \mathrm{R}$ have concluded that there are two possible orientations for both $m$ CPBG and granisetron (Joshi et al. 2006; Schulte et al. 2006).

Comprehensive reports can be found elsewhere on the binding sites of 5- $\mathrm{HT}_{3}$ (Schulte et al. 2006; Thompson \& Lummis, 2006), nACh (Romanelli et al. 2007), Gly (Lynch, 2004) and GABA receptors (Abdel-Halim et al. 2008; Huang et al. 2006; Korpi et al. 2002; Sedelnikova et al. 2005).

\subsection{Allosteric modulation}

Cys-loop receptors are allosteric proteins, but they themselves are also subject to allosteric modulation by a wide range of organic and inorganic substances (Changeux et al. 1984). Some of these substances occur endogenously and may reinforce or attenuate the natural response under physiological conditions, but, given the central importance of Cys-loop receptors in the nervous system and neurological disorders, it is not surprising that some synthetic receptor modulators are widely used potent and effective drugs, such as the benzodiazepines, which act at $\mathrm{GABA}_{\mathrm{A}}$ receptors. We will not attempt to describe the effects of all of these modulators, but will briefly describe some examples to give an indication of the diversity of compounds and the range of studies being undertaken to understand their mechanisms of action. Further information can be obtained from the following reviews for $\mathrm{GABA}_{\mathrm{A}}$ (Huang et al. 2006; Olsen et al. 2004b), Gly 
(A)

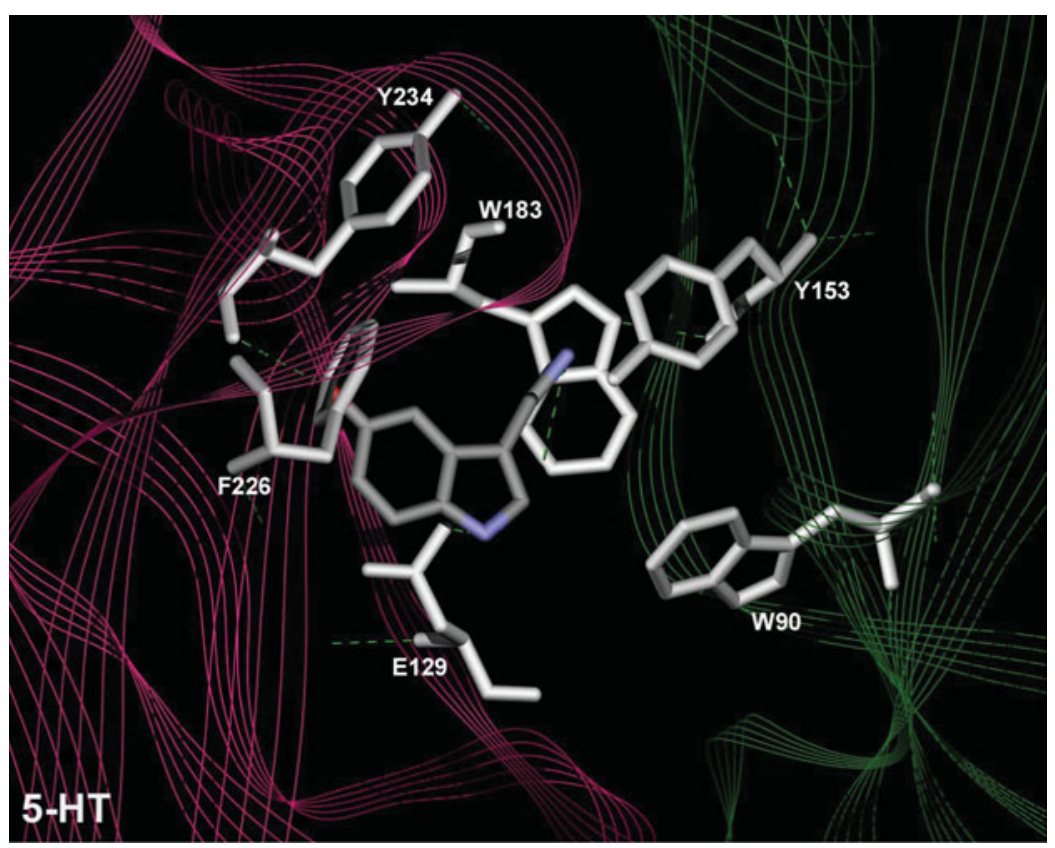

(B)

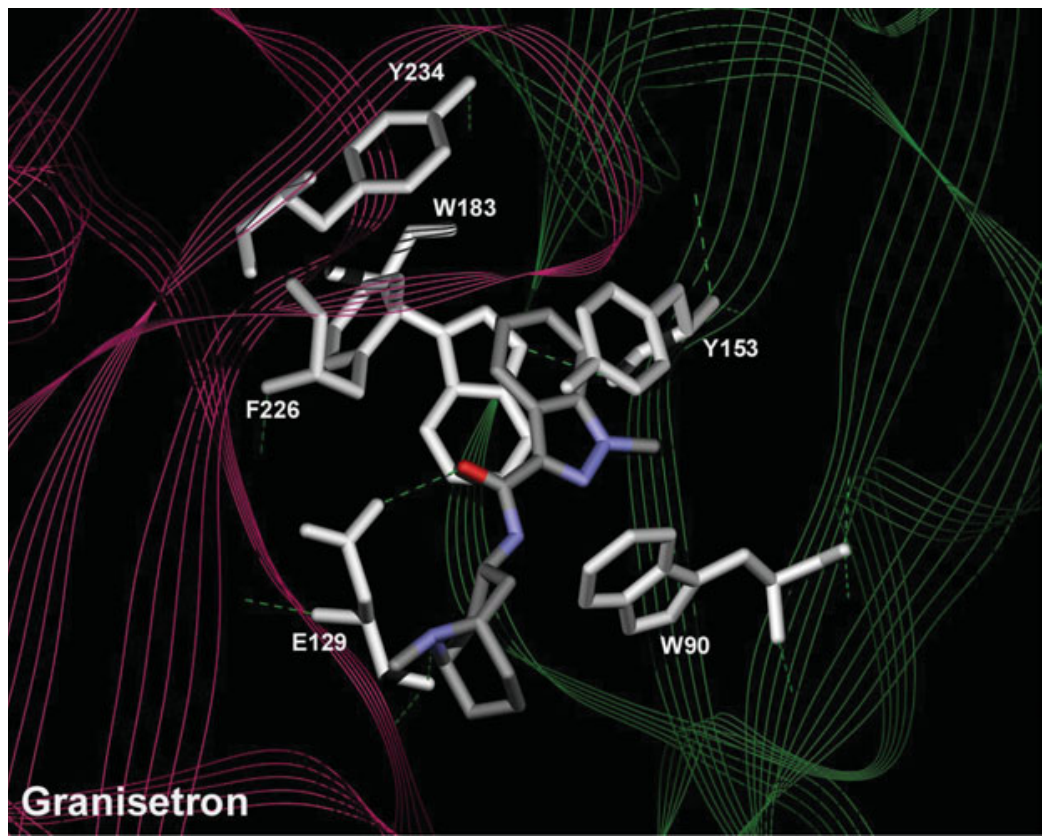

Fig. 9. Preferred orientations for 5-HT and granisetron docked into a homology model of the 5- $\mathrm{HT}_{3}$ receptor binding site. Both orientations provide the best fit for the experimental data. The ligands can potentially interact with W183, are influenced by a range of aromatic residues that are orientated with their $\pi$-rings normal to the ligand, and have critical hydrogen bonds interactions with E129. See text for more details. 
(Hawthorne \& Lynch, 2006; Lynch, 2004, 2009), nACh (Faghih et al. 2008; Arias \& Bouzat, 2006) and $5-\mathrm{HT}_{3}$ receptors (Reeves \& Lummis, 2002).

\subsection{Ions as modulators}

Receptors in the Cys-loop family can be significantly affected by physiologically relevant ions such as calcium, magnesium and zinc. The effects of these ions vary according to the receptor type and subunit composition. For example, in the $\alpha 7 \mathrm{nAChR}$, these cations potentiate responses, while 5- $\mathrm{HT}_{3} \mathrm{R}$ responses are typically reduced (Brown et al. 1998; Hu \& Lovinger, 2005; Hubbard \& Lummis, 2000; Niemeyer \& Lummis, 2001; Thompson \& Lummis, 2008a). Ionbinding sites in many Cys-loop receptors have been identified in the channel (Bertrand et al. 1993; Eddins et al. 2002a, 2002b; Gill et al. 1995; Hu \& Lovinger, 2005; Livesey et al. 2008; Niemeyer \& Lummis, 2001; Noam et al. 2008; Quirk et al. 2004; Thompson \& Lummis, 2008a; Van Hooft \& Wadman, 2003), but there are also binding sites in other regions of these proteins. A specific binding site for calcium, for example, has been identified in the ECD of the $\alpha 7 \mathrm{nACh}$ (Galzi et al. 1996), and insertion of this region into the $5-\mathrm{HT}_{3} \mathrm{R}$ results in an enhancement of the 5-HT-induced response. This region coincides with residues that have been shown to bind $\mathrm{Ca}^{2+}$ in AChBP (Brejc et al. 2001). Zinc-binding sites have been located at subunit interfaces in $\mathrm{nAChR}$ and GlyR (Hsiao et al. 2006; Nevin et al. 2003), while in $\mathrm{GABA}_{\mathrm{A}}$ receptors, zinc binds to both the ECD and the pore (Dunne et al. 2002; Fisher \& Macdonald, 1998; Fisher, 2002; Horenstein \& Akabas, 1998; Hosie et al. 2003). Binding of these ions is likely to have important physiological consequences although these are not yet fully understood. In the $\mathrm{GABA}_{\mathrm{A}}$ receptor, for example, sensitivity to zinc changes with the onset of epilepsy (Kapur \& Macdonald, 1997), an effect that has been genetically linked to a mutation within the M2 region of the $\mathrm{GABA}_{\mathrm{A}} \gamma 2$ subunit (Baulac et al. 2001).

\subsubsection{Benzodiazepines}

Benzodiazepines are an important class of therapeutic compounds that modulate $\mathrm{GABA}_{\mathrm{A}}$ receptors by binding at the $\alpha-\gamma$ subunit interface (Olsen \& Sieghart, 2009). Differences in the pharmacological profiles of different $\alpha$ - and $\gamma$-subunit subtypes have enabled the identification of amino-acid residues that are involved in benzodiazepine binding. For example, $\alpha 1$-His102 directly interacts with flunitrazepam and diazepam (Berezhnoy et al. 2004; McKernan et al. 1998; Tan et al. 2007), while $\alpha 1$-Tyr160, $\alpha 1$-Tyr210 (Amin et al. 1997) and $\gamma 2$-Phe77 (Buhr et al. 1997a) form part of the aromatic-binding site for benzodiazepines. Residues $\alpha 1$-Thr206, $\alpha 1$-Glu209, $\alpha 1$-Tyr162, $\alpha 1$-Thr207, $\gamma$ 2-Tyr58, $\gamma$ 2-Ala79, $\gamma 2$-Met130 and $\gamma 2$-Thr142 contribute to benzodiazepine selectivity and efficacy (Buhr \& Sigel, 1997; Buhr et al. 1997a, 1997b; Kucken et al. 2000; Mihic et al. 1994; Sigel \& Buhr, 1997; Teissere \& Czajkowski, 2001).

The mechanisms that communicate conformational changes between the GABA- and benzodiazepine-binding sites are less well understood. Mutations in loop $\mathrm{F}$ of the $\gamma_{2}$ subunit do not change the binding affinity of benzodiazepines or the agonist response, but decrease potentiation, indicating that this region may be involved in telegraphing the modulatory behaviour to other areas of the receptor (Hanson \& Czajkowski, 2008; Padgett \& Lummis, 2008). Other regions of the protein are also probably involved, including the $\beta 10$ sheet of the ECD (see Fig. 3), and residues in M1, M2 and the M2-M3 loop (Boileau \& Czajkowski, 1999; Jones-Davis 
et al. 2005). Further reading on benzodiazepines can be found in Olsen \& Sieghart (2009), Rudolph et al. (2001) and Sigel (2002).

\subsubsection{Alcohols and anaesthetics}

A wide range of alcohols and anaesthetics modulate Cys-loop receptor function, and their behaviours are mostly mediated via interactions with the TMD (Arias \& Bhumireddy, 2005; Hawthorne \& Lynch, 2006; Huang et al. 2006; Sessoms-Sikes et al. 2003). Effects of these compounds vary according to the receptor type, subunit composition, and the nature and concentration of compound being used. For example, long $n$-alkanols and anaesthetics are inhibitory at nAChRs, but ethanol is potentiating at low concentrations (Zuo et al. 2002), while 5- $\mathrm{HT}_{3} \mathrm{Rs}$ are potentiated and inhibited depending upon the alcohol or anaesthetic (e.g. Machu \& Harris, 1994; Suzuki et al. 2002; Zhang et al. 1997). Other examples include $\alpha 4 \beta 2 \mathrm{nAChRs,} \mathrm{which} \mathrm{are} \mathrm{sensitive}$ to the anaesthetics isoflurane and propofol, and $\alpha \beta \gamma \delta \mathrm{nACh}$ and $\alpha 7 \mathrm{nAChRs}$ which are not (Flood et al. 1997; Violet et al. 1997). There are many other examples, and there are excellent reviews on this subject by Arias \& Bhumireddy (2005), Urban et al. (2006) and Yamakura et al. (2001).

\subsubsection{Ivermectin - a commercially important modulator of invertebrate $\mathrm{GluCl}$ receptors}

Ivermectin, a macrocyclic lactone produced by bacteria, is the world's largest-selling veterinary drug, and has also largely eradicated 'river blindness' resulting from nematode infections in subSaharan Africa. Ivermectin, its avermectin analogues and the milbemycins are probably allosteric potentiators of invertebrate $\mathrm{GluCl}$ channels at submicromolar concentrations (Vassilatis et al. 1997). These heteromultimeric channels, found in several invertebrate phyla, are homologous to vertebrate GlyR (and slightly less so to $\mathrm{GABA}_{\mathrm{A}}$ receptors).

We know little about the binding site for ivermectin, but because the $\mathrm{GluCl}$ channels resemble other Cys-loop receptors, it is certain that the $\mathrm{GluCl} \beta$ subunit carries the principal-binding site. The GluCl $\beta$ Tyr182 residue aligns with the loop B cation $-\pi$ residues: Trp of the nAChR, Trp of the $5-\mathrm{HT}_{3} \mathrm{R}$ and (probably most similar) Phe of the GlyR (see Table 1). Substitutions to several other residues at this position abolish the responses to both glutamate and ivermectin. However, the $\mathrm{GluCl} \beta$-Y182F mutation decreases the maximal glutamate response by $\sim 6$-fold, without changing the ivermectin response ( $\mathrm{Li}$ et al. 2002). This is evidence that the binding sites for glutamate and IVM do not overlap. Twenty other mutations were studied in the $\beta$-subunit ECD; none preserved glutamate sensitivity while abolishing ivermectin sensitivity ( $\mathrm{Li}$ et al. 2002). Therefore, we cannot say where ivermectin binds to $\mathrm{GluCl}$ channels.

GlyR are also activated by ivermectin, but are $\sim 1000$-fold less sensitive (Shan et al. 2001), suggesting that ivermectin may act differently on GlyR. Nevertheless, several GlyR-binding site mutations abolish glycine but not ivermectin sensitivity, supporting the idea that the agonist and ivermectin sites do not overlap (Shan et al. 2001). Also supporting the idea that ivermectin binds at a non-agonist site, voltage-clamp fluorometry established that the $19^{\prime}$ residue near the top of M2 changes its environment when the channel is opened by all agonists but not when opened by ivermectin (Pless et al. 2007).

A mystery associated with ivermectin is its very low reversibility, which vitiates concentrationresponse experiments. Ivermectin effects take $>8 \mathrm{~h}$ to wash out and this lower limit could actually be governed by a synthesis of new receptors (Slimko et al. 2002). The most appropriate experiments show that $\mathrm{GluCl}$ channels are half-activated by ivermectin during a $1 \mathrm{nM}$ puff lasting 
several seconds (Slimko \& Lester, 2003). In unpublished experiments (HAL lab), hypersensitive nAChR mutants with comparably low $\mathrm{EC}_{50}$ values show washout time constants of several minutes; therefore, simple high affinity does not explain the long washout times for ivermectin at GluCl channels. An unnatural Pro substitute in the M2-M3 linker of 5- $\mathrm{HT}_{3} \mathrm{Rs}$ produces an apparently irreversible activation (Lummis et al. 2005b) with an $\mathrm{EC}_{50}$ of $20 \mathrm{nM}$, and may represent a good analogy to the action of ivermectin. Further comments on ivermectin can be found in sections 3.3.5 and 7.5.

\subsection{5 $\alpha 7$ nACh receptor allosteric modulators}

Among the nAChRs, the $\alpha 7 \mathrm{nAChR}$ has received recent attention as a target for allosteric activators (Bertrand et al. 2008; Hogg \& Bertrand, 2007). Potent positive allosteric modulators include NS-1738, 4-naphthalene-1-yl-3a,4,5,9b-tetrahydro-3- $H$-cyclopenta[c]quinoline-8-sulfonic acid amide (TQS), PNU-120596, $N$-(4-chlorophenyl)- $\alpha$-[[(4-chloro-phenyl)amino] methylene]3-methyl-5-isoxazoleacet-amide ('compound 6'; Ng et al. 2007), LY-2087101(Broad et al. 2006) and galanthamine (Lopes et al. 2007); these act at concentrations $\leqslant 10 \mu \mathrm{M}$. TQS and PNU120596, but not NS1738, have the property that they either reactivate desensitized receptors and/or significantly retard desensitization, properties that are also shared by ivermectin at GlyR (Gronlien et al. 2007). However, according to results from $\alpha 7 / 5-\mathrm{HT}_{3}$ chimeras, NS-1738 and PNU-12059 bind at different sites. The ECD of the $\alpha 7 \mathrm{nAChR}$ is required for NS-1738 action, and the ECD in combination with the M2-M3 linker of the $\alpha 7 \mathrm{nAChR}$ are required for agonistindependent activity in the presence of NS-1738 (Bertrand et al. 2008). In contrast, the entire TMD of the $\alpha 7 \mathrm{nAChR}$ is required for allosteric modulation by PNU-12059 (Bertrand et al. 2008).

\section{The TMD}

\section{I Structure}

A range of experimental techniques show that the TMD is composed of four membrane spanning $\alpha$-helices (M1-M4) from each subunit; each receptor therefore has 20 such $\alpha$-helices within the membrane (Fig. 10). The $\alpha$-helical nature of these regions, which was originally inferred from hydropathy plots (Noda et al. 1982), was verified in the nAChR by photolabelling (Blanton \& Cohen, 1994), two-dimensional ${ }^{1} \mathrm{H}-\mathrm{NMR}$ spectroscopy (Lugovskoy et al. 1998), Fourier transform infrared (FTIR) spectroscopy (Baenziger \& Methot, 1995; Corbin et al. 1998; GörneTschelnokow et al. 1994; Methot et al. 1994) and mutagenesis (e.g. Tamamizu et al. 2000). The best available structural information comes from $4 \AA$ resolution cryo-electron microscopy images of the nAChR (Miyazawa et al. 2003); higher-resolution structures from related prokaryotic receptors have been solved, but it is not yet clear how representative these are of vertebrate Cysloop receptors (Bocquet et al. 2009; Hilf \& Dutzler, 2008; Nury et al. 2009). The $4 \AA \mathrm{nAChR}$ images show that $\alpha$-helices from each subunit are arranged symmetrically, forming an inner ring of M2 helices that line the central pore, and an outer ring composed of M1, M3 and M4 that shields the inner ring from the lipid environment (De Planque et al. 2004; Miyazawa et al. 2003). On the extracellular side, the transmembrane helices are spread apart, but gather together as they cross the membrane towards the intracellular side (Goren et al. 2004; Miyazawa et al. 2003; Panicker et al. 2002). Overlaying electron densities of subunits in the resting state reveals that M1, 


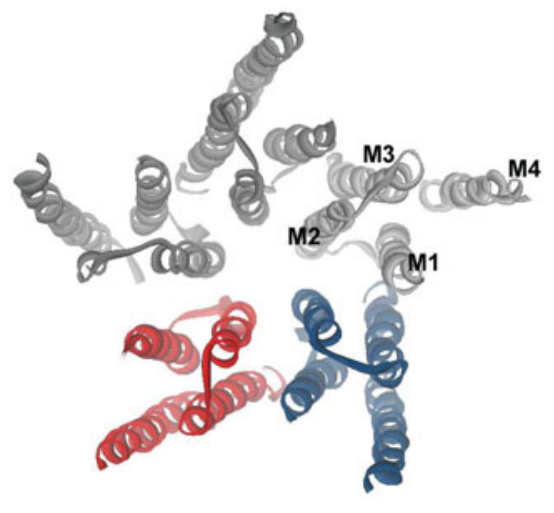

nACh

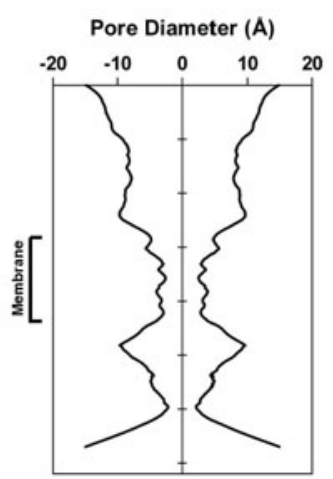

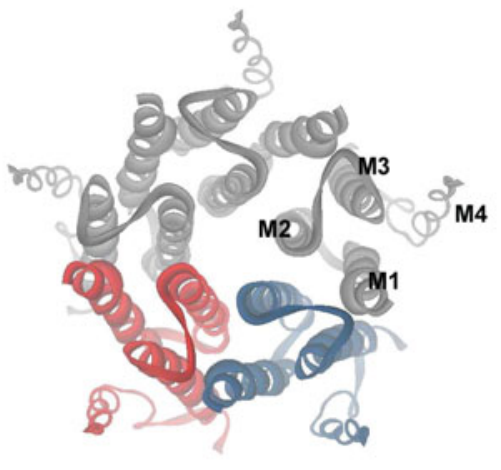

ELIC

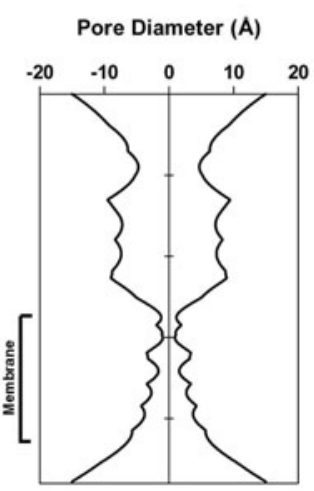

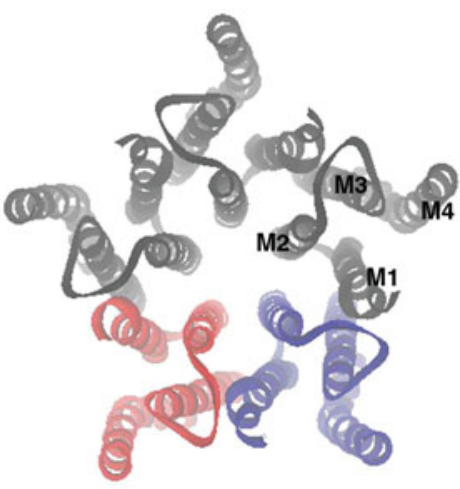

GLIC

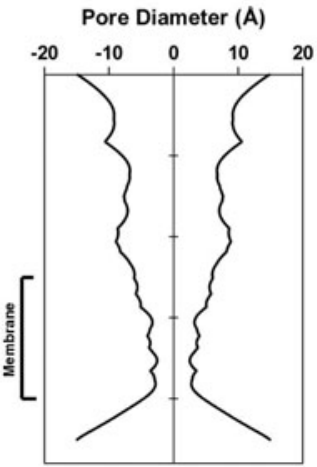

Fig. 10. Comparisons of TMDs from open and closed receptors. Top panel: structures of nAChR (closed; Mivazawa et al. 2003; PDB ID: 2BG9), ELIC (closed; Hilf \& Dutzler, 2008; PDB ID: 2VL0) and GLIC (open; Bocquet et al. 2007; PDB ID: 3EAM) are shown. Two (red and blue) of the five subunits are highlighted. M2 lines the central pore, and residues that face this water accessible surface are shown in Fig. 11. Lower panels: pore diameter as calculated by HOLE, with a 15 A cut-off to find the ends of the pores (Smart et al. 1993). Each tick on the vertical axis is $25 \AA$. The nAChR pore appears longer, because the structure also contains part of the ICD. 
M2 and M3 have precise positioning within the structure while the location of M4 is more relaxed, particularly at its C-terminus. A review of pore structures can be found in Absalom et al. (2009).

\section{2 $\mathrm{MI}$ and the $\mathrm{MI}-\mathrm{M} 2$ loop}

M1 forms part of the outer ring that is in contact with the lipid environment and may also contact M2. Mutations in M1 have been shown to produce receptors that have altered desensitization, changes in $\mathrm{EC}_{50}$ or are non-functional (Akabas \& Karlin, 1995; Bianchi et al. 2001; Dang et al. 2000; Engblom et al. 2002; England et al. 1999; Greenfield et al. 2002; Lobitz et al. 2001; Lobo et al. 2004; Spitzmaul et al. 2004; Zhang \& Karlin, 1997). M1 may therefore be a structural element involved in transmitting movement of the ligand-bound ECD into M2, possibly through direct interactions with the M2 helix following activation (Unwin et al. 2002). Indeed, some of the roles of specific residues that contribute to this activity are beginning to emerge. For example, the highly conserved proline residue in the centre of M1 has been shown to be critical due to its lack of ability to act as a hydrogen bond donor (Dang et al. 2000), and may permit M2 to transiently alter its position upon channel activation. Recent experiments introducing ionizable side chains into M1 revealed the current response is reduced $25-50 \%$ by protonation at any of five $\alpha$-helically spaced M1 side-chains, suggesting M1 is not completely shielded from the channel axis by M2. The data also show that the side chains closest to the axis in the open state are also those closest in the cryo-electron microscopy studies, revealing that M1 moves little, or may not move at all, between the open and closed states (Cymes \& Grosman, 2008; Miyazawa et al. 2003).

There is evidence that the region that links M1 with the ECD is an important functional element involved in the gating process. Mutations at the extracellular end of the $5-\mathrm{HT}_{3} \mathrm{R}(\mathrm{R} 222$, Hu et al. 2003), GlyR (R218, Castaldo et al. 2004), GABA $\mathrm{R}$ (K215, Kash et al. 2004) and nAChR (several residues, Zhang \& Karlin, 1997) have been shown to effect receptor gating. The other end of M1 may form part of the intracellular mass that lies at the cytoplasmic face of the pore. Evidence from SCAM has indicated that the intracellular end of M1 and the M1-M2 linker lie along the path of the permeating ions, and these regions contain residues responsible for anion/ cation selectivity (Filippova et al. 2004; also see section 4.4). Coordination of cadmium ions in $5-\mathrm{HT}_{3} \mathrm{R}$ Cys mutants and the use of negatively and positively charged thiol reactive MTS reagents have demonstrated that residues in the M1-M2 loop are accessible (Panicker et al. 2002, 2004).

\subsection{M2 lines the channel pore and acts as the channel gate}

A great number of experiments over many years have shown that the residues in M2 line the channel pore and M2 is an $\alpha$-helix. In particular, substituting cysteine, histidine, lysine or arginine residues into M2 has revealed water-accessible pore lining residues that have a periodicity consistent with an $\alpha$-helical conformation (Akabas et al. 1994; Cymes et al. 2005; Reeves et al. 2001; Xu \& Akabas, 1996; Zhang \& Karlin, 1998). Structural data from cryo-electron microscopy indicate that M2 is $\sim 40 \AA$ long and extends beyond the embrace of the lipid environment (Bachy et al. 1993; Miyazawa et al. 2003). These data also show that within the limits of the membrane the M2 helices tilt radially towards the centre of the pore until they reach residues $6^{\prime}-9^{\prime}$, a region that is considered to be the channel gate (Fig. 10). This is consistent with earlier 


\begin{tabular}{|c|c|c|c|c|c|}
\hline \multirow{3}{*}{ Extracellular } & $\underline{5-\mathrm{HT}_{3} \mathrm{~A}}$ & Ach $\alpha 1$ & & $\mathrm{GABA}_{\mathrm{A}} \propto 1$ & Glycine o \\
\hline & D298 & E262 & $20^{\prime}$ & N275 & D276 \\
\hline & 1294 & L258 & $16^{\prime}$ & 1271 & A280 \\
\hline \multirow{4}{*}{$\begin{array}{l}\text { Hydrophobic } \\
\text { Region }\end{array}$} & V291 & V255 & $13^{\prime}$ & T268 & G283 \\
\hline & L287 & L251 & $9^{\prime}$ & L264 & T287 \\
\hline & T284 & $\mathrm{S} 248$ & $6^{\prime}$ & T261 & L290 \\
\hline & $\mathrm{S} 280$ & T244 & $2^{\prime}$ & V257 & T294 \\
\hline Intermediate & E277 & E241 & $-1^{\prime}$ & A254 & S297 \\
\hline Cytoplasmic & D274 & D238 & $-4^{\prime}$ & E250 & A301 \\
\hline
\end{tabular}

\begin{tabular}{|c|c|c|c|c|c|c|c|c|c|c|c|c|c|c|c|c|c|c|c|c|c|c|c|c|c|}
\hline & $-4^{\prime}$ & & & $-1^{\prime}$ & & & $2^{\prime}$ & & & & $6^{\prime}$ & & & & & & & & & & $16^{\prime}$ & & & & \\
\hline$-\mathrm{HT}_{3} \mathrm{~A}^{1}$ & D & $\mathrm{S}$ & G & . $\mathrm{E}$ & $\mathbf{R}$ & V & $\mathrm{S}$ & $\mathbf{F}$ & & & $\mathrm{T}$ & L & L & & & $Y$ & $\mathbf{S}$ & V & $\mathbf{F}$ & L & I & $I$ & V & & \\
\hline$A^{2}$ & D & $\mathrm{S}$ & G & $\mathbf{E}$ & $\mathbf{R}$ & V & $\mathbf{S}$ & E & & & $\mathbf{T}$ & L & L & & G & $\mathrm{Y}$ & S & & $\mathbf{F}$ & L & I & [ & 7 & & \\
\hline$-\mathrm{HT}_{3} \mathrm{~A}^{3}$ & 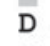 & $\mathrm{S}$ & G & E & $\mathbf{R}$ & V & S & & K & & $\mathrm{T}$ & L & L & L & G & $\mathrm{Y}$ & & & $\mathbf{F}$ & L & I & $I$ & V & & \\
\hline $\mathrm{Ch} \propto 1^{4}$ & D & $\mathrm{S}$ & G & E & $\mathrm{K}$ & $\mathbf{M}$ & $\mathrm{T}$ & & & & S & V & L & & & L & & & & L & L & V & {[} & & \\
\hline $\mathrm{ABA}_{\mathrm{A}} \propto 1$ & E & $\mathrm{S}$ & V & $\mathrm{P}$ & $\mathbf{R}$ & $\mathrm{T}$ & V & F & 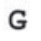 & & $\mathbf{T}$ & $\mathrm{T}$ & $\mathrm{V}$ & & $\mathrm{T}$ & M & & $\mathbf{T}$ & L & S & $I$ & s & A & & \\
\hline $1 y \propto 16,7$ & D & $\mathrm{A}$ & & P & $R$ & V & & & & & $\mathbf{T}$ & $\mathrm{T}$ & V & & & & & & & & $\mathrm{S}$ & G & $S$ & & \\
\hline
\end{tabular}

Fig. 11. M2 channel lining residues in different Cys-loop receptors. Pore-lining residues are shown next to the M2 $\alpha$-helix (taken from the nAChR structure; PDB ID: 1oed). To allow for comparisons between M2 residues of different Cys-loop receptors, a prime (') notation is used: residues are assigned numbers according to their position relative to a charged M2 residue that is conserved in Cys-loop receptors. Residues that are accessible to modification are highlighted : ${ }^{1}$ Kaneez \& White (2004), ${ }^{2}$ Reeves et al. (2001), ${ }^{3}$ Panicker et al. (2002), ${ }^{4} \mathrm{Akabas}$ et al. (1994), ${ }^{5} \mathrm{Xu} \&$ Akabas (1996), ${ }^{6}$ Shan et al. (2002), ${ }^{7} \mathrm{Lynch}$ et al. (2001) and ${ }^{8} \mathrm{Lobo}$ et al. (2004). Accession numbers for the sequence alignment are: Mouse 5- $\mathrm{HT}_{3} \mathrm{~A}, \mathrm{Q} 6 \mathrm{~J} 1 \mathrm{~J} 7$; Electric Ray ACh $\alpha 1, \mathrm{P} 02710$; Human $\mathrm{GABA}_{\mathrm{A}}, \alpha 1$ P14867; Human Gly $\alpha 1$, P23414.

studies that showed the binding site for the open-channel blocker QX-222 was located at the region between $6^{\prime}$ and $10^{\prime}$ of the $\mathrm{nAChR}$, and suggested that the open channel tapered to its narrowest point just below 6' (Charnet et al. 1990; Leonard et al. 1988).

The centre of the pore coincides with a conserved collar of hydrophobic side chains; in the nAChR $\alpha 1$ subunit this includes Leu251, Val255 and Leu258 (Figs 1, 2, 10 and 11). Five symmetrically placed M2 helices from each of the five subunits create a hydrophobic region that is $3 \AA$ at its narrowest and less than $3.5 \AA$ over a distance of approximately $8 \AA$ in the closed state, and has been referred to as a hydrophobic girdle (Miyazawa et al. 2003). Ion permeabilities suggest that the diameter of the open channel is between $7.4 \AA$ and $8.4 \AA$ for cation channels and between $5.2 \AA$ and $6 \cdot 2 \AA$ for anion channels (Brown et al. 1998; Cohen et al. 1992; Fatima-Shad \& Barry, 1993; Rundstrom et al. 1994; Wang \& Imoto, 1992). Originally, the channel gate was predicted to be close to the cytoplasmic end of M2 (Wilson \& Karlin, 1998; Wilson et al. 2000). This conclusion was supported by data from applying thiol reactive compounds in the closed or open state of the receptor, but the results were limited as channels may spontaneously open, modifying reaction rates can vary in the presence and absence of agonist and some of the modifying reagents may be small enough to pass the closed gate (Bali \& Akabas, 2007; Tikhonov 
et al. 2004; Wilson \& Karlin, 2001). It is now widely accepted that the gate is located in the centre of the channel. This constricted region shares structural similarities to the gate of other membrane-permeable channels which are also occluded by a narrow hydrophobic region (Chang et al. 1998), and represents the only obstruction within the channel that provides an energetic barrier to ion permeation (Beckstein et al. 2001; Hummer et al. 2001).

\subsection{M2 and ion selectivity}

The residues that line the ion-accessible inner face of the channel are predominantly non-polar except for rings of charged amino acids (Figs 1 and 11) (Akabas et al. 1992, 1994; Panicker et al. 2002; Reeves et al. 2001; Xu \& Akabas, 1993; Xu et al. 1995; Zhang \& Karlin, 1998). Initially, Konno et al. (1991) reported that the three rings of charged amino acids (referred to as extracellular, intermediate and cytoplasmic rings) in the $\mathrm{nAChR} \mathrm{M2} \mathrm{region} \mathrm{were} \mathrm{responsible} \mathrm{for} \mathrm{ion}$ selectivity, with the intermediate ring exerting the strongest influence (Fig. 11). The mechanisms of charge selectivity were later evaluated by substituting M2 residues of the $\alpha 7 \mathrm{nAChR}$ with the corresponding residues from Gly $\alpha 1$ (Galzi et al. 1992). As the number of mutations was gradually reduced, the smallest number of residues required to reverse ion selectivity was found to be valine to threonine (V251T or V9'T), neutralization of a glutamate (E237A or E-1'A) and the insertion of a proline (P236 or P-2) in the M1-M2 loop. Homologous changes also alter ion selectivity in the $5-\mathrm{HT}_{3}$ (Gunthorpe \& Lummis, 2001; Thompson \& Lummis, 2003), MOD-1 (Menard et al. 2005), GABA $\rho$ (Carland et al. 2004; Wotring et al. 2003), GABA $\mathrm{A}$ (Jensen et al. 2002, 2005a) and Gly $\alpha 1$ receptors (Keramidas et al. 2000). The contribution of each of the three mutations was studied in more detail in the $\alpha 7 \mathrm{nAChR}$, and showed that the residue at the $-1^{\prime}$ position is the most critical (Corringer et al. 1999a). At this position in cationic receptors glutamate predominates, while the $-1^{\prime}$ residue in anionic receptors is uncharged (Keramidas et al. 2002; Wotring et al. 2003). In the $\alpha 7 \mathrm{nAChR} \mathrm{V9'}$ was found not to be directly involved in charge selectivity, and the effect of the Pro insertion was the result of localized structural modifications at the intracellular end of M2 (Corringer et al. 1999a). Indeed, in the $\alpha 7 \mathrm{nAChR}$, functional anionic channels could be generated by inserting a Pro at any of the positions 234, 236 or 237, although was dependent on being accompanied by the E237A and V251T mutations. The structural importance of the Pro was further illustrated by changes in functional properties of the mutant receptors, including differences in activation, desensitization, $\mathrm{EC}_{50}$, Hill co-efficient and spontaneous channel openings (Corringer et al. 1999a; Wotring et al. 2003). At the invertebrate $\mathrm{GluCl}$ receptor, charge selectivity remains unaltered in similar Pro mutants and a structural role was also concluded (Sunesen et al. 2006). Further complications were presented in a study by Wotring \& Weiss (2008), who also showed that the introduction of Glu residues within an eight amino-acid stretch $\left(-2^{\prime}\right.$ to 5$)$ of GABA $\rho 1$ produces varied permeability ratios depending upon the location of the substitution. However, in native receptors the character of the $-1^{\prime}$ residue is conserved across the Cys-loop family, indicating that this position is critical. Consequently, the ring of charge at the $-1^{\prime}$ position is now universally regarded as an essential component of charge selectivity within the Cys-loop family, with other residues in the region playing some roles in some receptors.

Mutations in the $5-\mathrm{HT}_{3} \mathrm{R}$ close to the extracellular ring of charge have also been implicated in charge selectivity (Thompson \& Lummis, 2003). When the 19' residue is changed from a serine to an arginine and combined with the $-1^{\prime}$ Glu to Ala mutation, the receptor is predominantly anion selective. Importantly, unlike the triple mutants described above, these $5-\mathrm{HT}_{3} \mathrm{R}$ mutants 
do not display concomitant changes in the biophysical properties of the channel, suggesting that these data more accurately reflect the residues directly involved in ion selectivity. Neutralization of R19' in the GlyR, however, does not alter ion selectivity when expressed in conjuncture with $\mathrm{A} 1^{\prime} \mathrm{E}$ and $\mathrm{P} 2{ }^{\prime} \Delta$ mutations, although it does modify conductance and rectification (Keramidas et al. 2002; Moorhouse et al. 2002). These data indicate that there are structural differences between the cation- and anion-selective receptors (also see section 4.5).

As functional receptors can be formed from different combinations of subunits (which have different amino acids lining their pores), there can be large differences in the permeation of certain ions. One of these is $\mathrm{Ca}^{2+}$, and nAChRs have a wide range of $\mathrm{Ca}^{2+}$ permeabilities (Arias, 2006; Cens et al. 1997; Gerzanich et al. 1998; Livesey et al. 2008; Noam et al. 2008; Tapia et al. 2007; Vernino et al. 1992) determined primarily by the residues located at the intermediate $(-1$ ) and extracellular (20') rings (Bertrand et al. 1993; Galzi et al. 1992; Hu \& Lovinger, 2005; Livesey et al. 2008). For example, reduced $\mathrm{Ca}^{2+}$ conductance in $(\alpha 4)_{2}(\beta 2)_{3} \mathrm{nAChRs}$ compared to $(\alpha 4)_{3}(\beta 2)_{2}$ nAChRs is a consequence of only $\beta 2$, but not $\alpha 4$ subunits having acidic residues at their $-1^{\prime}$ positions (Tapia et al. 2007). Such data can be extrapolated to other receptors: $5-\mathrm{HT}_{3} \mathrm{ABR}$ have lower $\mathrm{Ca}^{2+}$ permeability than $5-\mathrm{HT}_{3} \mathrm{AR}$, which may be the consequence of $20^{\prime}$ residue being Asp and Asn in A and B subunits, respectively. Consistent with this, a D20'A substitution reduces $\mathrm{Ca}^{2+}$ permeability, as does the replacement of the adjacent R19' with Ser (Livesey et al. 2008; Thompson \& Lummis, 2003). Recent studies suggest that the ICD may also play a role in $\mathrm{Ca}^{2+}$ permeability as substitutions of charged residues in this region can have a major effect on $\mathrm{Ca}^{2+}$ permeability (Livesey et al. 2008; Thompson \& Lummis, 2003). In both nAChR and $5-\mathrm{HT}_{3} \mathrm{Rs}, \mathrm{Ca}^{2+}$ binding sites have also been reported in the ECD (see section 3.3.1).

Comprehensive reviews on ion selectivity in the Cys-loop family of receptors can be found in Jensen et al. (2005b), Keramidas et al. (2004), Peters et al. (2010) and Sine et al. (2010).

\subsection{The M2-M3 loop}

The M2-M3 loop forms part of the interface that links the ECD with the TMD, and it has a critical role in transmitting the energy of binding into channel opening (discussed further in section 6). Studies have shown that mutations in this region disrupt activation in $\mathrm{nACh}, 5-\mathrm{HT}_{3}$, GABA and Gly receptors (Campos-Caro et al. 1996; Deane \& Lummis, 2001; Grosman et al. 2000a, 2000b; Kusama et al. 1994; Lewis et al. 1998; Lynch et al. 1997; O’Shea \& Harrison, 2000; Rajendra et al. 1995; Rovira et al. 1998, 1999; Saul et al. 1999; Sigel et al. 1999). The structure of this loop has been examined by a range of techniques, including NMR and electron microscopy, and the data suggest that there are differences between cation- and anion-selective receptors. In the $\mathrm{nAChR}$, the M2 helix extends two rings above the membrane (i.e. up to the $23^{\prime}$ residue), while in the GlyR, the helix terminates at the $15^{\prime}$ residue (Ma et al. 2005). The loop moves during receptor activation; in the Gly $\alpha 1$ receptor, SCAM studies reveal that all the residues within the M2-M3 region are accessible to modification, and surface accessibility increases when the receptor is activated (Bera et al. 2002; Lynch et al. 2001). Specific residues in this loop play particular roles, for example, in the $5-\mathrm{HT}_{3} \mathrm{R}$ a cis-trans isomerization of the Pro at the apex of this loop (Pro308, P8) can trigger channel opening (Lummis et al. 2005b). While the same mechanism seems not to activate the $\mathrm{nAChR}$, the equivalent proline functionally couples to flanking Val residues extending from the $\beta 1-\beta 2$ and Cys-loops, and together these regions form a critical part of the transduction pathway (Lee et al. 2008). A conserved proline within the Cys-loop has also 
been identified as a candidate for channel activation (Limapichat et al. 2010). This topic is also discussed in section 6 .

\subsection{M3 and M4 helices}

Structural data show that M3 and M4 are $\alpha$-helical and shield M2 from the lipid bilayer, although there are water-accessible clefts that lie between the TMD $\alpha$-helices (Miyazawa et al. 2003; Fig. 10). SCAM studies on the M3 segment of $\mathrm{GABA}_{\mathrm{A}}$ receptors show that in the absence of GABA, only those residues towards the extracellular side of the membrane are accessible. Activation allows modifying reagents to approach residues located closer to the centre of the M3 $\alpha$-helix, as water-permeable clefts between adjacent $\alpha$-helices widen as a consequence of conformational changes in M2 (Miyazawa et al. 2003; Wang et al. 1999; Williams \& Akabas, 1999). The outer face of the M3 helix is in close contact with the membrane and is inaccessible to these modifying agents (Blanton \& Cohen, 1992, 1994; Blanton et al. 1998). Recent nAChR experiments introduced ionizable side chains into M3 to reveal relative distance from the channel's axis, similar to the experiments performed in M1 and M2 (Cymes et al. 2005). The extent of block was $<40 \%$ for only five side chains, limiting the precision of the data, but was not inconsistent with the $\alpha$-helical pattern and orientation of the closed state found in structural studies. M3, like M1, apparently rotates little between the closed and open states.

Given the location and apparent roles of M3 and M4, it is surprising that mutations can have significant effects on receptor function, but such mutations cause changes in both the whole-cell current (Cruz-Martin et al. 2001; Guzman et al. 2003; Lasalde et al. 1996; Williams \& Akabas, 1999; Wu et al. 2010) and single-channel kinetics of nAChRs and 5- $\mathrm{HT}_{3} \mathrm{Rs}$ (Bouzat et al. 2000, 2002; Corradi et al. 2009; De Rosa et al. 2002; Lee et al. 1994; Navedo et al. 2004; Ortiz-Miranda et al. 1997; Tamamizu et al. 1999, 2000; Wang et al. 1999). The effect of these mutations can be additive both in terms of the contribution from each subunit (Bouzat et al. 1998; De Rosa et al. 2002) and within the same $\alpha$-helix (Lasalde et al. 1996), although this observation is not supported by all studies (Cruz-Martin et al. 2001). M4 may also detect the lipid environment and influence the functional properties of the receptor (daCosta \& Baenziger, 2009).

These regions also influence receptor expression: the number and characteristics of C-terminal residues in M4 are critical for the expression of $5-\mathrm{HT}_{3} \mathrm{R}$ on the cell surface (Butler et al. 2009) and the expression of non-assembling receptors that contain only the ECD and M1-M3 helices can be rescued by co-expression with M4 (Haeger et al. 2010; Villmann et al. 2009). Thus, the M3 and M4 regions are an integral part of the receptor, and have a function that extends beyond simply shielding M2 from the membrane.

\section{The ICD}

\section{I Structure}

The structure of the ICD is unresolved apart from a single $\alpha$-helix that is located in the M3-M4 loop of each subunits. Electron microscopy-derived images at $9 \AA$ resolution show that the ICD adopts a 'hanging-basket'-type structure with openings or 'portals' that are the likely site of ion entry and exit to/from the channel (Hales et al. 2006; Unwin, 1993). One side of each portal is contributed by the $\alpha$-helix described above. This amphipathic $\alpha$-helix was 
originally identified by sequence analysis many years ago and was considered to line the pore (Finer-Moore \& Stroud, 1984; Miyazawa et al. 1999). More recent studies have shown that it contributes significantly to the channel conductance in both nAChRs and 5- $\mathrm{HT}_{3} \mathrm{Rs}$ (Hales et al. 2006; Peters et al. 2005). Interestingly, homologous receptors in bacteria do not have an extended loop region between M3 and M4, which has led to experiments where this region was deleted in $5-\mathrm{HT}_{3} \mathrm{Rs}$ and $\mathrm{GABA}_{\mathrm{C}} \mathrm{Rs}$, demonstrating that these receptors maintained most of the characteristics of the parent receptor (Bocquet et al. 2007; Hilf \& Dutzler, 2008; Jansen et al. 2008). Thus, these regions are not essential for function or expression.

\subsection{Channel conductance}

Studies that demonstrated a role of the M3-M4 loop in channel conductance were originally performed in the $5-\mathrm{HT}_{3} \mathrm{R}$, and more recently extended to $\mathrm{nAChRs}$ and GlyRs (Carland et al. 2009; Deeb et al. 2007; Hales et al. 2006; Kelley et al. 2003; Livesey et al. 2008; Peters et al. 2004). In the $5-\mathrm{HT}_{3} \mathrm{R}, \mathrm{A}$-subunits can form functional homomeric channels with a conductance $<1 \mathrm{pS}$, but when combined with B-subunits receptors display a much larger conductance ( $9-17 \mathrm{pS}$; Brown et al. 1998; Davies et al. 1999; Derkach et al. 1989; Hussy et al. 1994). By replacing parts of the A-subunit sequence with homologous regions from the B-subunit, Kelley et al. (2003) identified three amino acids that govern the differences between the low conductance of the homomeric receptor and the higher conductance of the heteromeric receptor, and which align with a polar stripe of residues identified by Finer-Moore \& Stroud (1984). Electrophysiological data support the suggestion that the charged groups line portals within the sides of the ICD, and influence the ion flux between the cytoplasm and the inner vestibule at the base of the pore (Miyazawa et al. 1999; Unwin, 2000). As the widest region of the portals resembles the diameter of a hydrated permeant ion, they provide an explanation for the homomeric $5-\mathrm{HT}_{3}$ channel having a much smaller unitary conductance than most nAChRs, despite their similar ionic permeabilities and very similar M2 sequences (Brown et al. 1998; Lambert et al. 1989; Malone et al. 1991; Mochizuki et al. 2000; Yakel et al. 1990; Yang, 1990). Additional studies have shown that the conductance of the channel can be dynamically altered by sulphydryl modifying reagents (Deeb et al. 2007) and the permeability of divalent cations is also altered by mutations in this region (Livesey et al. 2008). A peptide that mimics this region at $\mathrm{GABA}_{\mathrm{A}} \mathrm{Rs}$ similarly modulates conductance at inside-out patches (Everitt et al. 2009). Charged residues at this location have also been proposed to interact with phosphate groups on intracellular proteins, regulating both channel conductance and ion selectivity (Livesey et al. 2008; Noam et al. 2008).

\subsection{Intracellular modulation}

Interactions of proteins and ions with the M3-M4 loop of Cys-loop receptors can modulate receptor activity, assembly, targeting and trafficking (e.g. Akk \& Steinbach, 2000; Bouzat et al. 1994; Boyd et al. 2002; Melzer et al. 2010; Yu \& Hall, 1994). Some interactions are highly specific to different subunits of different receptors, such as gephyrin that specifically targets GlyR to postsynaptic synapses, while others are more general; phosphorylation of the M3-M4 loop, for example, is linked to changes in channel behaviour in $\mathrm{nACh}, 5-\mathrm{HT}_{3}, \mathrm{GABA}_{\mathrm{A}}$ and Gly receptors (Filippova et al. 2000; Hubbard et al. 2000; Lankiewicz et al. 2000; McDonald \& Moss, 1994; McDonald \& Moss, 1997; Moss et al. 1992, 1996; Nishizaki \& Ikeuchi, 1995; Nishizaki \& Sumikawa, 1998; Ruiz-Gomez et al. 1991; Sedelnikova \& Weiss, 2002; Vaello et al. 1994; 
Van Hooft \& Vijverberg, 1995; Wecker et al. 2001). A comprehensive series of reviews by Connolly (2008), Gaimarri et al. (2007), Kneussel \& Loebrich (2007), Millar (2008), Millar \& Harkness (2008) and Sarto-Jackson \& Sieghart (2008) cover the assembly and trafficking of nACh, 5- $\mathrm{HT}_{3}, \mathrm{GABA}_{\mathrm{A}}$ and Gly receptors.

A variety of kinases including casine kinase II, tyrosine kinase, protein kinase A (PKA) and protein kinase $\mathrm{C}(\mathrm{PKC})$ phosphorylate different residues with differing effects. For example, PKA phosphorylates Ser409 in the $5-\mathrm{HT}_{3} \mathrm{R}$ causing an increase in the rate of desensitization (Coultrap and Machu, 2002; Hubbard et al. 2000; Lankiewicz et al. 2000; Sun et al. 2003; Yakel et al. 1990), while PKC actions on this receptor regulate the probability of certain conductance states (Coultrap \& Machu, 2002; Van Hooft \& Vijverberg, 1995) and rapidly increase surface expression (Emerit et al. 2002; Grailhe et al. 2004; Ilegems et al. 2004; Sun et al. 2003). Other processes of post-translational modulation such as protein glycosylation and palmitoylation have also been described, but the exact roles of these processes in the regulation of receptor assembly, targeting and trafficking are not yet fully determined (e.g. Boyd et al. 2002; Drisdel et al. 2004; Green et al. 1995).

\section{Molecular basis of Cys-loop receptor activation}

Binding of an agonist to its receptor causes movements of the ECD that are transduced to the M2 helices and lead to the opening of the pore (e.g. Grosman et al. 2000b; Lee et al. 2009; Unwin et al. 2002). In the heteromeric nAChR, this movement is initiated within the $\alpha$-subunits, which undergo rotations, although several recent studies also describe movements that precede rotation (Horenstein et al. 2001; Lape et al. 2008; Pless \& Lynch, 2009; Unwin et al. 2002). The structural integrity of the ECD is important as weakening backbone hydrogen bonds in the $\beta 7, \beta 9$ and $\beta 10$ sheets abolish receptor function, while photochemically cleaving the backbone between loops A and $\mathrm{E}$ has similar effects on GABA activation, but not on activation by pentobarbital (Gleitsman et al. 2009; Hanek et al. 2010). The movement of the ECD, mediated by the M2-M3 linker at the extracellular side of the TMD, destabilizes the hydrophobic 'girdle' in the channel, which moves away from the centre of the pore into space that resides between the inner and outer rings, opening the channel (Law et al. 2000; Miyazawa et al. 2003). It is often claimed that Miyazawa et al. (2003) found a 'rotation' in the M2 regions, but only rotations in the ECD were identified, along with two alternative structures of the M2 helices: straight in the closed state and kinked in the open state. The cytoplasmic ends of M2 remain relatively static during these events (Panicker et al. 2002, 2004). In support of this hypothesis, mutations of the gate residues affect ion permeation, cause increased sensitivity to channel opening, slow desensitization of macroscopic currents, increase closing events and/or increase channel open times (Chang \& Weiss, 1998; Filatov \& White, 1995; Labarca et al. 1995). A collective movement of all the M2 helices is likely, as they maintain their five-fold symmetry in both the closed and open states (Unwin, 1995), and the gate residue $\alpha \mathrm{L} 251$ effects pore opening independent of the nAChR subunit type mutated (Filatov \& White, 1995; Labarca et al. 1995). Gating of Cys-loop receptors can occur in the absence of bound ligand, but at very low frequency (e.g. Jackson, 1984, 1986; Hu \& Peoples, 2008). The binding of ligand increases the probability of opening and maximizes as the quantity of bound ligands rises to at least two (Beato et al. 2004; Corradi et al. 2009). As the channel opening rate can be quicker than the dissociation rate of the ligand, several openings can occur during a single ligand occupancy. 
Electron microscopy studies (Miyazawa et al. 2003; Unwin et al. 2002) have indicated that the $\beta 1-\beta 2$ and $\beta 8-\beta 9$ loops and the $\beta 10$ strand in the ECD are closely associated with residues in the M2-M3 linker, providing a direct link between the ECD and TMD (Lee et al. 2008; Unwin, 1995; Unwin et al. 2002). Comparing the structures of the ELIC (apparent closed conformation) and GLIC (apparent open conformation) prokaryotic receptors also shows distinct differences in this region (Bocquet et al. 2009; Hilf \& Dutzler, 2008). In support of the structural data, experiments show that coupling of binding to gating in a chimaeric AChBP (ECD)/5- $\mathrm{HT}_{3}$ (ICD) receptor could only be achieved when these three amino-acid loops from the ECD of the $5-\mathrm{HT}_{3} \mathrm{R}$ were substituted into the corresponding regions of AChBP. This indicates that compatibility between the two regions is necessary (Bouzat et al. 2004), although subsequent studies which could not repeat these functional data led these authors to conclude that AChBP is in the desensitized form (Grutter et al. 2005b). Specific residues in the loops at the ECD/TMD interface have been identified as playing roles in the transduction process; in particular, a salt-bridge between the ECD and TMD regions has

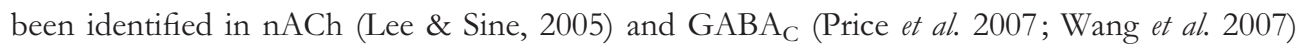
receptors. However, there is no such salt bridge between the equivalent residues in $\mathrm{GABA}_{\mathrm{A}} \mathrm{R}$ (Kash et al. 2003, 2004), 5- $\mathrm{HT}_{3}$ (Price et al. 2007) or GlyR (Schofield et al. 2003), although it is clear that charged residues are important. A good explanation for these results is that there is a global electrostatic attraction between the two regions (Dougherty, 2008; Xiu et al. 2005). A series of recent reviews have summarized current knowledge of the changes that induce channel opening (Bartos et al. 2009; Cederholm et al. 2009; Chang et al. 2009; Gay \& Yakel, 2007).

\section{Time-resolved structural information}

It has long been a goal of biophysicists to understand the conformational changes in an ion channel at sufficient time resolution (a) to link each structure to a functionally defined state, and possibly (b) to visualize the transition states as well. This goal remains elusive for two reasons. (1) Some Cys-loop receptors desensitize within a few ms after opening, and therefore, structural measurements must have sufficient temporal resolution to distinguish between active and desensitized states. (2) We do not yet understand the kinetic bases of equilibrium side chain parameters such as polarity, polarizability, volume and (in the case of Pro), backbone cis-trans isomerization, or how such properties govern the kinetics of changes in the secondary and tertiary structures of proteins. Therefore, results from site-directed mutagenesis alone cannot usually be interpreted in kinetic terms.

\section{I Time-resolved cryo-electron microscopy}

Conceptually, the clearest approach is Unwin's pioneering experiment that obtained cryo-electron microscopy data at $9 \AA$ resolution from Torpedo nAChR-rich membranes, both in the closed state, and $\sim 5$ ms after ACh was sprayed onto the membrane (Unwin, 1995). Unwin identified rotations in the ECD and two alternative structures of the M2 helices; straight in the closed state and kinked in the open state. These measurements may eventually be brought to the $4 \AA$ resolution of Unwin's later cryo-electron studies (Unwin, 2005), but are currently insufficiently resolved to identify the orientation of individual amino-acid side chains. 


\subsection{Time-resolved mass spectrometry}

As detailed in section 4, state-dependent cross-linking and SCAM experiments reveal that residues change their distance from each other, or their water-accessibility, as the channel opens, closes and desensitizes. A complementary technique uses photoaffinity labelling during periods when the Cys-loop receptor is in the open, closed or desensitized state. Using this technique, the membrane was kept intact to allow voltage control manipulations; oocytes expressing $\mathrm{nAChR}$ were exposed to constant ACh during a voltage-clamp experiment. The receptors, which have voltage-dependent gating, were switched from open to closed by voltage jumps. The oocyte was exposed to the lamp during $500 \mathrm{~ms}$ epochs that coincided with either the open or closed states (Leite et al. 2003). Because of the photoprobe concentrates in the membrane, mass spectrometry then revealed regions whose exposure to the membrane changed during the state transitions. In the open state, there was specific probe incorporation within the ECD in the $\beta 8-\beta 9$ loop. In the closed state, probe incorporation occurred within the Cys-loop, and these findings agree well with present concepts about the gating interface. In the closed state, there was also probe incorporation in the M3-M4 region, emphasizing that this region too may move relative to the membrane during gating (Akk \& Steinbach, 2000; Bouzat et al. 1994).

\subsection{Light-flash relaxations}

Other strategies produce a perturbation at a structurally defined location, and then ask how the receptor relaxes with a new equilibrium. The kinetics of the relaxation then reveal the speed of a conformational change that propagates from the perturbed residue to the channel gate(s). Unfortunately, the location of voltage dependence is unknown in those Cys-loop receptors (such as the muscle $\mathrm{nAChR}$ ) that display voltage-dependent kinetics. However, light-flash relaxations are more informative, because they originate at known locations. In one example, the photoisomerizable nicotinic agonist Bis-Q was photoisomerized from the active, trans configuration to the non-agonist cis configuration while the Bis-Q molecule was bound to the binding site. Channels closed completely within $<100 \mu$ s showing that dissociation of the agonist and channel closure are linked to this time scale (Nass et al. 1978; Sheridan \& Lester, 1982). The photon cross-section for this closure corresponds to two Bis-Q molecules per channel, showing that this conclusion applies to either of the two bound agonists. Information of this sort can be obtained only indirectly from other kinetic studies.

In another example, the unnatural side chain Tyr-ONB, or caged Tyr, was introduced in place of the Tyr residues in the nAChR $\alpha$ subunit at loop A (Tyr93), near the Cys-loop (Tyr127) or in loop C (Tyr198). The mutant receptor did not respond to ACh. Flash decaging, in the presence of ACh, produced conductance increases that covered a wide range of time scales ( $1 \mathrm{~ms}$ to $10 \mathrm{~s}$ ), with at least two phases in each case (Miller et al. 1998). The faster phase $(\tau 1)$ was governed by the time course of the flash $(\sim 1 \mathrm{~ms})$; this is important, because it implies that changing any of these side chains to the native Tyr activates the gate within $\sim 1 \mathrm{~ms}$. The time constant of the slower phase $(\tau 2)$ was considerably slower: $\tau 2$ at Tyr127 (13 ms) was faster than for Tyr198 (41 ms) or for Tyr93 $(820 \mathrm{~ms})$. We now understand that Tyr127 is closer to the channel gate than are the other two side chains, and we also know that Tyr198 is on a loop that moves when agonist binds in AChBP (Zheng \& Zagotta, 2003). On the other hand, in most models, Tyr93 does not participate directly in conformational changes that open the channel. Thus, a structural 
change in a side chain influences the conductance more rapidly when it directly participates in the gating pathway.

\subsection{Rate-equilibrium free energy relationships}

Rate-equilibrium free energy relationships (REFERs) provide a more general way to specify the order at which various residues participate in the conformational changes that open and close the gate (Edelstein et al. 1996; Grosman et al. 2000b). In this analysis, one performs a kinetic experiment that can distinguish the rate of channel opening from that of channel closing. This can be accomplished with macroscopic measurements, but is most simply done by measuring singlechannel kinetics at agonist concentrations so high that they saturate the binding step. The kinetic and equilibrium data are compared for a set of mutations at a residue under investigation. If the data are well behaved, they yield a parameter $0<\Phi<1$, which indicates the proximity of the transition state controlled by the residue of interest. Values of $\Phi$ near 0 and 1 indicate that a transition state is nearest to the open or closed state, respectively. Strikingly, the initial investigation showed that progression of $\Phi$, from near 1 to near 0 , approximated the physical position of residues from extracellular (near the binding site) to intracellular (near the channel gate), respectively (Chakrapani et al. 2003; Grosman et al. 2000b). These data led to the conclusion that opening proceeds in a conformational wave, from the binding site to the channel gate. Evidently, the $\Phi$ values imply both mechanistic order and temporal order.

More recent analyses have shown clusters of $\Phi$ values for neighbouring residues, giving rise to the idea that domains of the receptor move together and allowing the ordering of conformational changes that involve various domains. Thus, a recent analysis concludes that the residues at the top of $\alpha$-M2 region move at about the same time as the binding site (Bafna et al. 2008). Later in the conformational wave, the M2 regions have several distinct steps at $\Phi$ values between 0.64 and $0 \cdot 31$ (Purohit et al. 2007).

\subsection{Voltage-clamp fluorometry}

Voltage-clamp fluorometry provides another way to identify changes in the local structure. Fluorescence changes $(\Delta F)$ that differ from conductance changes are the more interesting, whether these differences occur along the axis of time, agonist concentration, blocker concentration or agonist efficacy. In the usual experiment, an introduced Cys residue is derivatized with a Cys-reactive fluorophore whose fluorescence is highly dependent on local polarity. The typical probe, tetramethylrhodamine, increases its fluorescence by factors approaching 100 when its environment becomes less polar. We do not yet fully understand the photophysical nature of the relation between conformational changes and fluorescence, but can simply say that a $\Delta F$ means a local change in the environment. Indeed, several Cys-loop experiments show that the sign (positive or negative) of $\Delta F$ varies with position for closely spaced residues (Muroi et al. 2006; Dibas et al., HAL lab). We call this the 'sign caution'. One must also rule out a direct interaction between the tethered fluorophore and the ligand under test, as well as making sure that the ligand does not have a fluorescent signature of its own.

Following the lead of experiments on voltage-gated channels and neurotransmitter transporters, voltage-clamp fluorometry measurements usually involve a voltage-clamped oocyte, because the large measureable membrane area provides better signal to noise ratios than experiments on an individual voltage-clamped mammalian cell. The excised inside-out patch procedure, which has proven to be useful for cyclic nucleotide-gated channels (Zheng and Zagotta, 2003), is less 
useful for channels gated by extracellular ligands and therefore has not been employed. There are also indications that covalently bound fluorophores can sense structural changes in the $\mathrm{GABA}_{\mathrm{A}} \mathrm{R}$ that presumably originate at binding interfaces, and then propagate to a non-binding subunit that has the fluorescent label (Muroi et al. 2006).

Concentration-response relationships are possible when the maximal $\Delta F / F$ (e.g. signal/ background) exceeds $\sim 2 \%$. The data for $\mathrm{GABA}_{\mathrm{A}}$ and $\mathrm{GABA}_{\mathrm{C}}$ receptors show that fluorophores tethered to loops $\mathrm{A}, \mathrm{C}$ and $\mathrm{E}$ undergo agonist-induced conformational changes that change the fluorescence of bound fluorophores; these fluorescence changes have the same concentration-response relationship as the conductance (Chang \& Weiss, 2002). Thus, we have another indication that part of the ECD moves as the channel opens; but the small $\Delta F / F$ prevented experiments that would compare the kinetics of the fluorescence changes and conductance changes. Interestingly, fluorophores in loops A (Chang \& Weiss, 2002) and E (Chang \& Weiss, 2002; Muroi et al. 2006) experience antagonist-induced fluorescence decrease, opposite to the agonist-induced changes. This difference eliminates concerns about the 'sign caution'. On the other hand, a fluorophore in loop $\mathrm{C}$ exhibits similar changes whether the binding site is occupied by agonists or antagonists (Chang \& Weiss, 2002). These findings about antagonists could not have been obtained from mutagenesis alone. Because of the 'sign caution', the results do not conflict with recent conclusions, mostly based on AChBP, that agonists allow loop C to collapse on the agonist, while antagonists tend to push loop $\mathrm{C}$ away from the other loops (Gao et al. 2006; Hansen et al. 2005). Picrotoxin, a pore blocker, does not induce $\Delta F$ by itself (Muroi et al. 2006), but partially blocked $\Delta F$ for a loop $E$ position, fully blocked $\Delta F$ for a loop $A$ position, and failed to block $\Delta F$ for a loop $C$ position (Chang \& Weiss, 2002). Pore block is a complex kinetic and equilibrium phenomenon and detailed concentration-response experiments for both agonist and blocker would be required to resolve the question of whether a fluorophore in the ECD senses a different environment when the channel is blocked by picrotoxin (Lester, 1992).

The largest $\Delta F / F(10-20 \%)$ has been measured for the environment-sensitive fluorophore, tetramethylrhodamine (TMR) tethered at the extracellular end (typically close to the channel lining residue 19') of the M2 region at the muscle nAChR (Dahan et al. 2004) or GlyR (Pless et al. 2007). These signals enable spectrally resolved studies on the fluorescence, verifying the expectation (from studies in solution) that the emission spectrum shifts towards the blue as the emission increases. The original report concerned the muscle nAChR $\beta$-subunit containing TMR tethered to the $19^{\prime} \mathrm{Cys}$ mutation; but signals almost as large have now also been found for the $\gamma 19^{\prime}$ and $\delta 19^{\prime}$ positions as well (Dibas et al., unpublished results). The concentrationresponse relations for agonist-induced $\Delta F$ are shifted well to the left of those for agonist-induced current, implying that conformational changes occur at concentrations too low to open the channel. Further experiments led to the conclusion that $\beta 19^{\prime}$ positions events that closely follow agonist binding at the $\alpha \delta$ interface. In this case, $\Delta F / F$ was sufficiently large to allow kinetic studies, down to a time resolution of $\sim 5 \mathrm{~ms}$. The kinetic studies showed that one or more desensitized states of the $\mathrm{nAChR}$ retain the fluorescence increase, consistent with the idea that most desensitized receptors have agonist bound. The question arose, does $\Delta F$ arise solely from one or more desensitized states? The answer is no, because when the receptors were activated by a flash-induced increase of the agonist trans-Bis-Q, $\Delta F$ was complete with $20 \mathrm{~ms}$, one to two orders of magnitude faster than desensitization (Dahan et al. 2004).

Experiments with tetramethylrhodamine tethered to a GlyR 19' Cys residue show that large $\Delta F / F$ has the same Gly concentration-response relation as the Gly-induced conductance 
(Pless et al. 2007). But $\beta$-alanine and taurine produced robust $\Delta F$ without appreciably activation. Propafol converted taurine and $\beta$-alanine to full agonists, yet failed to produce a Gly-like blueshifted emission spectrum. Thus, as in the nAChR, TMR at $19^{\prime}$ reports a conformational change associated with a binding event in the ECD that occurs in the absence of channel opening. On the other hand, ivermectin, suspected of acting in the TMD, activates the channel without inducing $\Delta F$. Strychine, which competes at the binding site, blocks $\Delta F$; picrotoxin, which blocks the channel, does not reduce $\Delta F$.

Voltage-clamp fluorometry has justified its promise as a procedure that can reveal conformational changes induced by ligands, separable from those associated with channel opening (Pless \& Lynch, 2008). Cys-loop receptors apparently have wondrously complex conformational states and flexibility. Unfortunately, voltage-clamp fluorometry has told us little about the specific nature of the additional conformations.

\subsection{Total internal reflection fluorescence}

Some of Axelrod's pioneering experiments with total internal reflection microscopy (TIRF) were performed on muscle nAChRs labelled with antibodies (Wang \& Axelrod, 1994). Since then, many investigators have appreciated that TIRF is an optimal technique for resolving membraneassociate proteins. Recent TIRF experiments with single-molecule resolution have utilized channels that incorporate fluorescent proteins to count subunits in various ion channels (Ulbrich \& Isacoff, 2007). In a further refinement of the channel- and subunit-counting theme, it is now possible to label nAChRs with fluorescent unnatural amino acids, which vastly decreases the possible structural perturbation produced by the fluorophore (Pantoja et al. 2009). It is also possible to count individual subunits with fluorescent ligands, either $\alpha$-BTX (Pantoja et al. 2009) or a Cy3-derivative of carbamoylcholine (Fujimoto et al. 2008). Within a given individual cell, there is good agreement among the estimates for the number of channels from electrophysiology, fused fluorescent proteins, the fluorescent unnatural side chain and fluorescent $\alpha$-BTX (Pantoja et al. 2009). It may also be possible to develop high-throughput assays for $5-\mathrm{HT}_{3} \mathrm{Rs}$ with TIRF detection of fluorescent ligands (Hovius et al. 1999).

The 'optical patch clamp' is an entirely different use of single-molecule TIRF microscopy (Demuro \& Parker, 2005). Cells are injected with a dye whose fluorescence increases when it binds $\mathrm{Ca}^{2+}$. When an $\mathrm{nAChR}$ channel opens, the resulting transient cytoplasmic microdomain of increased fluorescence is sufficiently close to the membrane to be visualized by TIRF. The increased fluorescence has a square-wave time course (at a temporal resolution of $\sim 2 \mathrm{~ms}$ ) and exhibits all the expected kinetics, pharmacology, dose-dependence and voltage dependence expected from single nAChR channels. The technique simultaneously images and resolves the opening of hundreds of channels. It is especially encouraging that muscle nAChRs and normal Ringer solutions were used in the experiment, because the muscle $\mathrm{nAChR}$ has a relatively lower $\mathrm{Ca}^{2+}$ permeability than most $\mathrm{nACh}$ and $5-\mathrm{HT}_{3} \mathrm{Rs}$, implying that nearly all receptors could be studied with the 'optical patch clamp'.

\section{Conclusions}

Members of the Cys-loop of LGICs display considerable structural and functional homology. In this review, we have seen how evidence from structural studies can often be applied across the 
whole family of receptors. Functional conservation cannot be better demonstrated than by the creation of chimaeric receptors that combine varying regions of the different family members to create new receptors that possess the functional properties of both receptors (i.e. Eisele et al. 1993; Galzi et al. 1996; Grutter et al. 2005a, b). Considering the level of sequence and structural similarity between members, it is not surprising that there is also cross-talk by agonists (e.g. Nakazawa et al. 1995; Macor et al. 2001) and antagonists within the group (e.g. Ballesetro et al. 2005; Broad et al. 2002; Drisdel et al. 2008; Gurley \& Lanthorn, 1998; Macor et al. 2001; Thompson \& Lummis, 2008b). There has already been considerable research on these receptors, and the more recent identification of new members (e.g. Histamine-gated (Beg \& Jorgensen, 2003; Bocquet et al. 2007; Davies et al. 2002; Zheng et al. 2002), EXP-1 (Beg \& Jorgensen, 2003), Zinc-activated (Davies et al. 2002), ELIC (Hilf \& Dutzler, 2008), proton-gated (Bocquet et al. 2007), glutamate-gated (Cully et al. 1994), MOD-1 (Ranganathan et al. 2000) and SsCl (Mounsey et al. 2007)) suggests that others still remain undiscovered. A combination of traditional experimental methods and some of the more recent developments described in section 7 will provide us with further insights, many of which will be widely applicable to the whole Cys-loop receptor family.

\section{Acknowledgements}

The authors' research is supported by the Wellcome Trust (SCRL, AJT; SCRL is a Wellcome Trust Senior Research Fellow in Basic Biomedical Science); the EU (SCRL; NeuroCypres FP7) and NIH (HAL).

\section{References}

Abdel-Halim, H., Hanrahan, J. R., Hibbs, D. E., Johnston, G. A. \& Chebib, M. (2008). A molecular basis for agonist and antagonist actions at $\mathrm{GABA}_{\mathrm{C}}$ receptors. Chemical Biology and Drug Design 71, 306-327.

Absalom, N. L., Schofield, P. R. \& Lewis, T. M. (2009). Pore structure of the Cys-loop ligand-gated ion channels. Neurochemical Research 34, 1805-1815.

AKabas, M. H. \& KarLin, A. (1995). Identification of acetylcholine receptor channel-lining residues in the M1 segment of the $\alpha$-subunit. Biochemistry 34, 12496-12500.

Akabas, M. H., Stauffer, D. A., Xu, M. \& Karlin, A. (1992). Acetylcholine receptor channel structure probed in cysteine-substitution mutants. Science 258, 307-310.

Akabas, M. H., Kaufmann, C., Archdeacon, P. \& Karlin, A. (1994). Identification of acetylcholine receptor channel-lining residues in the entire M2 segment of the alpha subunit. Neuron 13, 919-927.

AkK, G. \& STeinbach, J. H. (2000). Structural elements near the $\mathrm{C}$-terminus are responsible for changes in nicotinic receptor gating kinetics following patch excision. Journal of Physiology 527, 405-417.

Amin, J., Brooks-Kayal, A. \& Weiss, D. S. (1997). Two tyrosine residues on the alpha subunit are crucial for benzodiazepine binding and allosteric modulation of $\mathrm{GABA}_{\mathrm{A}}$ receptors. Molecular Pharmacology 51, 833-841.
Arias, H. R. (Ed.) (2006). Biological and Biophysical Aspects of Ligand-gated Ion Channel Receptor Superfamilies. Kerala, India: Research Signpost.

Arias, H. R. \& Bhumireddy, P. (2005). Anesthetics as chemical tools to study the structure and function of nicotinic acetylcholine receptors. Current Protein and Peptide Science 6, 451-472.

Arias, H. R. \& BouZAT, C. (2006). Modulation of nicotinic acetylcholine receptors by noncompetitive antagonists. In Biological and Biophysical Aspects of Ligand-Gated Ion Channel Receptor Superfamilies (Ed. H. R. Arias), Kerala, India: Research Signpost.

Auerbach, A. (2010). The gating isomerization of acetylcholine receptors. Journal of Physiology 588, 573-586.

Bachy, A., Heaulme, M., Giudice, A., Michaud, J. C., Lefevre, I. A., Soullhac, J., Manara, L., Emerit, M. B., Gozlan, H., Hamon, M., Keane, P. E., Soubrie, P. \& Lefure, G. (1993). SR 57227A: a potent and selective agonist at central and peripheral $5-\mathrm{HT}_{3}$ receptors in vitro and in vivo. European Journal of Pharmacology 237, 299-309.

Baenziger, J. E. \& Mетнот, N. (1995). Fourier transform infrared and hydrogen/deuterium exchange reveal an exchange-resistant core of alpha-helical peptide hydrogens in the nicotinic acetylcholine receptor. Journal of Biolical Chemistry 270, 29129-29137. 
Bafna, P. A., Purohit, P. G. \& Auerbach, A. (2008). Gating at the mouth of the acetylcholine receptor channel: energetic consequences of mutations in the $\alpha \mathrm{M} 2$-cap. PLoS ONE, 3, e2515.

Balduzzi, R., Cupello, A. \& Robello, M. (2002). Modulation of the expression of $\mathrm{GABA}_{\mathrm{A}}$ receptors in rat cerebellar granule cells by protein tyrosine kinases and protein kinase C. Biochimica et Biophysica Acta 1564, 263-270.

Bali, M. \& Akabas, M. H. (2007). The location of a closed channel gate in the $\mathrm{GABA}_{\mathrm{A}}$ receptor channel. Journal of General Physiology 129, 145-159.

Ballestero, J.A., Plazas, P. V., Kracun, S., GomezCasati, M. E., Taranda, J., Rothlin, C. V., Katz, E., Millar, N. S. \& Elgoyhen, A. B. (2005). Effects of quinine, quinidine, and chloroquine on $\alpha 9 \alpha 10$ nicotinic cholinergic receptors. Molecular Pharmacology 68: 822829.

Barnes, N. M., Hales, T. G., Lummis, S. C. \& Peters, J. A. (2009). The $5-\mathrm{HT}_{3}$ receptor - the relationship between structure and function. Neuropharmacology 56, 273-284.

Barrera, N. P., Herbert, P., Henderson, R. M., Martin, I. L. \& Edwardson, J. M. (2005). Atomic force microscopy reveals the stoichiometry and subunit arrangement of $5-\mathrm{HT}_{3}$ receptors. Proceedings of the National Academy of Sciences USA 102, 12595-12600.

Bartos, M., Corradi, J. \& Bouzat, C. (2009). Structural basis of activation of cys-loop receptors: the extracellular-transmembrane interface as a coupling region. Molecular Neurobiology 40, 236-252.

Baulac, S., Huberfeld, G., Gourfinkel-An, I., Mitropoulou, G., Beranger, A., Prud’Homme, J. F., Baulac, M., Brice, A., Bruzzone, R. \& Leguern, E. (2001). First genetic evidence of $\mathrm{GABA}_{\mathrm{A}}$ receptor dysfunction in epilepsy: a mutation in the $\gamma 2$-subunit gene. Nature Genetics 281, 46-48.

Beato, M., Groot-Kormelink, P. J., Colquhoun, D. \& SiviLOtTI, L. G. (2004). The activation mechanism of $\alpha 1$ homomeric glycine receptors. Journal of Neuroscience 24, 895-906.

Beckstein, O., Biggin, P. C. \& Sansom, M. S. P. (2001). A hyrdophobic gating mechanism for nanopores. Journal of Physical Chemistry B 105, 12902-12905.

Beene, D. L., Brandt, G.S., Zhong, W., Zacharias, N. M., Lester, H. A. \& Dougherty, D. A. (2002). Cation- $\pi$ interactions in ligand recognition by serotonergic $\left(5-\mathrm{HT}_{3} \mathrm{~A}\right)$ and nicotinic acetylcholine receptors: the anomalous binding properties of nicotine. Biochemistry 4132, 10262-10269.

Beene, D. L., Price, K. L., Lester, H. A., Dougherty, D. A. \& Lummis, S. C. (2004). Tyrosine residues that control binding and gating in the 5-hydroxytryptamine3 receptor revealed by unnatural amino acid mutagenesis. Journal of Neuroscience 24, 9097-9104.
Beg, A. A. \& Jorgensen, E. M. (2003). EXP-1 is an excitatory GABA-gated cation channel. Nature Neuroscience 6, 1145-1152.

Bera, A. K., Chatav, M. \& Akabas, M. H. (2002). $\mathrm{GABA}_{\mathrm{A}}$ receptor M2-M3 loop secondary structure and changes in accessibility during channel gating. Journal of Biological Chemistry 277, 43002-43010.

Berezhnoy, D., Nyfeler, Y., Gonthier, A., Schwob, H., Goeldner, M. \& Sigel, E. (2004). On the benzodiazepine binding pocket in $\mathrm{GABA}_{\mathrm{A}}$ receptors. Journal of Biological Chemistry 279, 3160-3168.

Bertrand, D., Galzi, J. L., Devillers-Thiery, A., Bertrand, S. \& Changeux, J. P. (1993). Mutations at two distinct sites within the channel domain M2 alter calcium permeability of neuronal $\alpha 7$ nicotinic receptor. Proceedings of the National Academy of Sciences USA 90, 6971-6975.

Bertrand, D., Bertrand, S., Cassar, S., Gubbins, E., Li, J. \& Gopalakrishnan, M. (2008). Positive allosteric modulation of the $\alpha 7 \mathrm{nAChR}$ : ligand interactions with distinct binding sites and evidence for a prominent role of the M2-M3 segment $7 \mathrm{nAChR}$ : ligand interactions with distinct binding sites and evidence for a prominent role of the M2-M3 segment. Molecular Pharmacology 74, 1407-1416.

Bhattacharya, A., Dang, H., Zhu, Q. M., Schnegelsberg, B., Rozengurt, N., Cain, G., Prantil, R., Vorp, D. A., Guy, N., Julius, D., Ford, A. P., Lester, H. A. \& Cockayne, D. A. (2004). Uropathic observations in mice expressing a constitutively active point mutation in the $5-\mathrm{HT}_{3} \mathrm{~A}$ receptor subunit. Journal of Neuroscience 24, 5537-5548.

Bianchi, M. T., HaAs, K. F. \& Macdonald, R. L. (2001). Structural determinants of fast desensitization and desensitization-deactivation coupling in GABAa receptors. Journal of Neuroscience 21, 1127-1136.

Blanton, M. P. \& Cohen, J. B. (1992). Mapping the lipidexposed regions in the Torpedo californica nicotinic acetylcholine receptor. Biochemistry 31, 3738-3750.

Blanton, M. P. \& Cohen, J. B. (1994). Identifying the lipid-protein interface of the Torpedo nicotinic acetylcholine receptor: secondary structure implications. Biochemistry 33, 2859-2872.

Blanton, M. P., Mccardy, E. A., Huggins, A. \& Parikh, D. (1998). Probing the structure of the nicotinic acetylcholine receptor with the hydrophobic photoreactive probes $\left[{ }^{125}\right.$ I]TID-BE and $\left[{ }^{125}\right.$ T]TIDPC/16. Biochemistry 37, 14545-14555.

Bocquet, N., Prado De Carvalho, L., Cartaud, J., Neyton, J., Le Poupon, C., Taly, A., Grutter, T., Changeux, J. P. \& Corringer, P. J. (2007). A prokaryotic proton-gated ion channel from the nicotinic acetylcholine receptor family. Nature 445, 116-119.

Bocquet, N., Nury, H., BaAden, M., Le Poupon, C., Changeux, J. P., Delarue, M. \& Corringer, P. J. (2009). X-ray structure of a pentameric ligand-gated ion 
channel in an apparently open conformation. Nature 457, 111-114.

Boess, F. G., Steward, L. J., Steele, J. A., Liu, D., Reid, J., Glencorse, T. A. \& Martin, I. L. (1997). Analysis of the ligand binding site of the $5-\mathrm{HT}_{3}$ receptor using site directed mutagenesis: importance of glutamate 106 . Neuropharmacology 36, 637-647.

Boileau, A. J. \& Czajkowski, C. (1999). Identification of transduction elements for benzodiazepine modulation of the $G_{A B A}$ receptor: three residues are required for allosteric coupling. Journal of Neuroscience 19, 10213-10220.

Bouzat, C., Bren, N. \& Sine, S. M. (1994). Structural basis of the different gating kinetics of fetal and adult acetylcholine receptors. Neuron 13, 1395-1402.

Bouzat, C., Roccamo, A. M., Garbus, I. \& Barrantes, F. J. (1998). Mutations at lipid-exposed residues of the acetylcholine receptor affect its gating kinetics. Molecular Pharmacology 54, 146-153.

Bouzat, C., Barrantes, F. \& Sine, S. (2000). Nicotinic receptor fourth transmembrane domain: hydrogen bonding by conserved threonine contributes to channel gating kinetics. Journal of General Physiology 115, 663-672.

Bouzat, C., Gumilar, F., Del Carmen Esandi, M. \& Sine, S. M. (2002). Subunit-selective contribution to channel gating of the M4 domain of the nicotinic receptor. Biophysical Journal 82, 1920-1929.

Bouzat, C., Gumilar, F., Spitzmaul, G., Wang, H. L., Rayes, D., Hansen, S. B., Taylor, P. \& Sine, S. M. (2004). Coupling of agonist binding to channel gating in an ACh-binding protein linked to an ion channel. Nature 430, 896-900.

Bower, K. S., Price, K. L., Sturdee, L. E., Dayrell, M., Dougherty, D. A. \& Lummis, S. C. (2008). 5Fluorotryptamine is a partial agonist at $5-\mathrm{HT}_{3}$ receptors, and reveals that size and electronegativity at the 5 position of tryptamine are critical for efficient receptor function. European Journal of Pharmacology 580, 291-297.

Boyd, G. W., Low, P., Dunlop, J. I., Robertson, L. A., Vardy, A., Lambert, J. J., Peters, J. A. \& Connolly, C. N. (2002). Assembly and cell surface expression of homomeric and heteromeric $5-\mathrm{HT}_{3}$ receptors: the role of oligomerization and chaperone proteins. Molecular and Cellular Neuroscience 21, 38-50.

Brady, C. A., Stanford, I. M., Ali, I., Lin, L., Williams, J. M., Dubin, A. E., Hope, A. G. \& Barnes, N. M. (2001). Pharmacological comparison of human homomeric $5-\mathrm{HT}_{3} \mathrm{~A}$ receptors versus heteromeric 5- $\mathrm{HT}_{3} \mathrm{~A} /{ }_{3} \mathrm{~B}$ receptors. Neuropharmacology 41, 282-284.

Brejc, K., Van Dijk, W. J., Klaassen, R. V., Schuurmans, M., Van Der Oost, J., Smit, A. B. \& Sixma, T. K. (2001). Crystal structure of an ACh-binding protein reveals the ligand-binding domain of nicotinic receptors. Nature 411, 269-276.

Broad, L. M., Felthouse, C., Zwart, R., Mcphie, G. I., Pearson, K. H., Craig, P. J., Wallace, L., Broadmore,
R. J., Boot, J. R., Keenan, M., Baker, S. R. \& Sher, E. (2002). PSAB-OFP, a selective $\alpha 7$ nicotinic receptor agonist, is also a potent agonist of the $5-\mathrm{HT}_{3}$ receptor. European Journal of Pharmacology 452, 137-144.

Broad, L. M., Zwart, R., Pearson, K. H., Lee, M., Wallace, L., Mcphie, G. I., Emkey, R., Hollinshead, S. P., Dell, C. P., Baker, S. R. \& Sher, E. (2006). Identification and pharmacological profile of a new class of selective nicotinic acetylcholine receptor potentiators. Journal of Pharmacology and Experimental Therapeutics 318, 1108-1117.

Brown, A. M., Hope, A. G., Lambert, J. J. \& Peters, J. A. (1998). Ion permeation and conduction in a human recombinant 5- $\mathrm{HT}_{3}$ receptor subunit $\left(\mathrm{h} 5-\mathrm{HT}_{3} \mathrm{~A}\right)$. Journal of Physiology 507, 653-665.

Bruss, M., Barann, M., Hayer-Zillgen, M., Eucker, T., Gothert, M. \& Bonisch, H. (2000). Modified 5-HT 3 A receptor function by co-expression of alternatively spliced human 5- $\mathrm{HT}_{3} \mathrm{~A}$ receptor isoforms. Naunyn Schmiedebergs Archives of Pharmacology 362, 392-401.

Butler, A. S., Lindesay, S. A., Dover, T. J., Kennedy, M. D., Patchell, V. B., Levine, B. A., Hope, A. G. \& Barnes, N. M. (2009). Importance of the C-terminus of the human $5-\mathrm{HT}_{3} \mathrm{~A}$ receptor subunit. Neuropharmacology 56, 292-302.

Buhr, A., Baur, R. \& Sigel, E. (1997a). Subtle changes in residue 77 of the gamma subunit of $\alpha 1 \beta 2 \gamma 2 \mathrm{GABA}_{\mathrm{A}}$ receptors drastically alter the affinity for ligands of the benzodiazepine binding site. Journal of Biolical Chemistry 272, 11799-11804.

Buhr, A., Schaerer, M. T., Baur, R. \& Sigel, E. (1997b). Residues at positions 206 and 209 of the alpha1 subunit of $\mathrm{GABA}_{\mathrm{A}}$ receptors influence affinities for benzodiazepine binding site ligands. Molecular Pharmacology 52, 676-682.

Buhr, A. \& Sigel, E. (1997). A point mutation in the $\gamma 2$ subunit of gamma-aminobutyric acid type A receptors results in altered benzodiazepine binding site specificity. Proceedings of the National Academy of Sciences USA 94, 8824-8829.

Campos-Caro, A., Sala, S., Ballesta, J. J., VicenteAgullo, F., Criado, M. \& Sala, F. (1996). A single residue in the M2-M3 loop is a major determinant of coupling between binding and gating in neuronal nicotinic receptors. Proceedings of the National Academy of Sciences USA 93, 6118-6123.

Carland, J. E., Moorhouse, A. J., Barry, P. H., Johnston, G. A. \& Chebib, M. (2004). Charged residues at the $2^{\prime}$ position of human $\mathrm{GABA}_{\mathrm{C}} \rho 1$ receptors invert ion selectivity and influence open state probability. Journal of Biological Chemistry 279, 54153-54160.

Carland, J. E., Cooper, M. A., Sugiharto, S., Jeong, H. J., Lewis, T. M., Barry, P. H., Peters, J. A., Lambert, J.J. \& Moorhouse, A. J. (2009). Characterization of the effects of charged residues in the intracellular loop on ion permeation in alpha1 glycine 
receptor channels. Journal of Biological Chemistry 284, 2023-2030.

Cashin, A. L., Petersson, E. J., Lester, H. A. \& Dougherty, D. A. (2005). Using physical chemistry to differentiate nicotinic from cholinergic agonists at the nicotinic acetylcholine receptor. Journal of the American Chemical Society 127, 350-356.

Castaldo, P., Stefanoni, P., Miceli, F., Coppola, G., Del Giudice, E. M., Bellini, G., Pascotto, A., Trudell, J. R., Harrison, N. L., Annunziato, L. \& Taglialatela, M. (2004). A novel hyperekplexia-causing mutation in the pre-transmembrane segment 1 of the human glycine receptor $\alpha 1$ subunit reduces membrane expression and impairs gating by agonists. Journal of Biological Chemistry 279, 25598-25604.

Cederholm, J. M., Schofield, P. R. \& Lewis, T. M. (2009). Gating mechanisms in Cys-loop receptors. European Biophysical Journal 39, 37-49.

Celie, P. H., Van Rossum-Fikkert, S. E., Van Dijk, W. J., Brejc, K., Smit, A. B. \& Sixma, T. K. (2004). Nicotine and carbamylcholine binding to nicotinic acetylcholine receptors as studied in AChBP crystal structures. Neuron 41, 907-914.

Celie, P. H., Kasheverov, I. E., Mordvintsev, D. Y., Hogg, R. C., VAn Nierop, P., VAn Elk, R., VAN Rossum-Fikkert, S. E., Zhmak, M. N., Bertrand, D., Tsetlin, V., Sixma, T. K. \& Smit, A. B. (2005a). Crystal structure of nicotinic acetylcholine receptor homolog AChBP in complex with an $\alpha$-conotoxin PnIA variant. Nature Structural and Molecular Biology 12, 582-588.

Celie, P. H., Klaassen, R. V., Van Rossum-Fikkert, S. E., Van Elk, R., Van Nierop, P., Smit, A. B. \& Sixma, T. K. (2005b). Crystal structure of acetylcholine-binding protein from Bulinus truncatus reveals the conserved structural scaffold and sites of variation in nicotinic acetylcholine receptors. Journal of Biological Chemistry 280, 26457-26466.

Cens, T., Nargeot, J. \& Charnet, P. (1997). $\mathrm{Ca}^{2+}$ permeability of muscle nicotinic acetylcholine receptor is increased by expression of the $\varepsilon$ subunit. Receptors and Channels 5, 29-40.

Chakrapani, S., Bailey, T. D. \& Auerbach, A. (2003). The role of loop 5 in acetylcholine receptor channel gating. Journal of General Physiology 122, 521-539.

Champtiaux, N., Gotti, C., Cordero-Erausquin, M., David, D. J., Przybylski, C., Lena, C., Clementi, F., Moretti, M., Rossi, F. M., Le Novere, N., Mcintosh, J. M., Gardier, A. M. \& Changeux, J. P. (2003). Subunit composition of functional nicotinic receptors in dopaminergic neurons investigated with knock-out mice. Journal of Neuroscience 23, 7820-7829.

Chang, G., Spencer, R. H., Lee, A. T., Barclay, M. T. \& ReEs, D. C. (1998). Structure of the MscL homolog from Mycobacterium tuberculosis: a gated mechanosensitive ion channel. Science 282, 2220-2226.
Chang, Y. \& Weiss, D. S. (1998). Substitutions of the highly conserved M2 leucine create spontaneously opening $\rho 1$ gamma-aminobutyric acid receptors. Molecular Pharmacology 53, 511-523.

Chang, Y. \& Weiss, D. S. (2002). Site-specific fluorescence reveals distinct structural changes with GABA receptor activation and antagonism. Nature Neuroscience 5, 1163-1168.

Chang, Y. C., Wu, W., Zhang, J. L. \& Huang, Y. (2009). Allosteric activation mechanism of the cys-loop receptors. Acta Pharmacolica Sinica 30, 663-672.

Changeux, J. P., Devillers-Thiery, A. \& Chemouilli, P. (1984). Acetylcholine receptor: an allosteric protein. Science 225, 1335-1345.

Charnet, P., Labarca, C., Leonard, R. J., Vogelaar, N. J., Czyzyk, L., Gouin, A., Davidson, N. \& Lester, H. A. (1990). An open-channel blocker interacts with adjacent turns of $\alpha$-helices in the nicotinic acetylcholine receptor. Neuron 4, 87-95.

Chen, L. (2010). In pursuit of the high-resolution structure of nicotinic acetylcholine receptors. Journal of Physiology 588, 557-564.

Cohen, B. N., Labarca, C., Davidson, N. \& Lester, H. A. (1992). Mutations in M2 alter the selectivity of the mouse nicotinic acetylcholine receptor for organic and alkali metal cations. Journal of General Physiology 100, 373-400.

Connolly, C. N. (2008). Trafficking of 5- $\mathrm{HT}_{3}$ and $\mathrm{GABA}_{\mathrm{A}}$ receptors. Molecular Membrane Biology 25, 293 301.

Corbin, J., Methot, N., Wang, H. H., Baenziger, J. E. \& Blanton, M. P. (1998). Secondary structure analysis of individual transmembrane segments of the nicotinic acetylcholine receptor by circular dichroism and Fourier transform infrared spectroscopy. Journal of Biological Chemistry 273, 771-777.

Corradi, J., Gumilar, F. \& Bouzat, C. (2009). Singlechannel kinetic analysis for activation and desensitization of homomeric 5- $\mathrm{HT}_{3} \mathrm{~A}$ receptors. Biophysical Journal 97, 1335-1345.

Corringer, P. J., Bertrand, S., Galzi, J. L., DevillersThiery, A., Changeux, J. P. \& Bertrand, D. (1999). Mutational analysis of the charge selectivity filter of the $\alpha 7$ nicotinic acetylcholine receptor. Neuron 22, 831-843. Corringer, P. J., Baaden, M., Bocquet, N., Delarue, M., Dufresne, V., Nury, H., Prevost, M. \& Van Renterghem, C. (2010). Atomic structure and dynamics of pentameric ligand-gated ion channels: new insight from bacterial homologues. Journal of Physiology 588, 565-572.

Coultrap, S. J. \& Machu, T. K. (2002). Enhancement of 5-hydroxytryptamine3A receptor function by phorbol 12-myristate, 13 -acetate is mediated by protein kinase $\mathrm{C}$ and tyrosine kinase activity. Receptors Channels 8, 63-70. 
Cromer, B. A., Morton, C. J. \& Parker, M. W. (2002). Anxiety over $\mathrm{GABA}_{\mathrm{A}}$ receptor structure relieved by AChBP. Trends in Biochemical Science 27, 280-287.

Cruz-Martin, A., Mercado, J. L., Rojas, L. V., Mcnamee, M. G. \& Lasalde-Dominicci, J. A. (2001). Tryptophan substitutions at lipid-exposed positions of the gamma M3 transmembrane domain increase the macroscopic ionic current response of the Torpedo californica nicotinic acetylcholine receptor. Journal of Membrane Biology 183, 61-70.

Cully, D. F., Vassilatis, D. K., Liu, K. K., Paress, P. S., Van Der Ploeg, L. H., Schaeffer, J. M. \& Arena, J. P. (1994). Cloning of an avermectin-sensitive glutamategated chloride channel from Caenorhabditis elegans. Nature 371, 707-711.

Cully, D. F., Paress, P. S., Liu, K. K., Schaeffer, J. M. \& Arena, J. P. (1996). Identification of a Drosophila melanogaster glutamate-gated chloride channel sensitive to the antiparasitic agent avermectin. Journal of Biological Chemistry 271, 20187-20191.

Cutting, G. R., Lu, L., O’Hara, B. F., Kasch, L. M., Montrose-Rafizadeh, C., Donovan, D. M., Shimada, S., Antonarakis, S. E., Guggino, W. B., Uhl, G. R. \& et al. (1991). Cloning of the gamma-aminobutyric acid (GABA) $\rho 1$ cDNA: a GABA receptor subunit highly expressed in the retina. Proceedings of the National Academy of Sciences USA 88, 2673-2677.

Cymes, G. D. \& Grosman, C. (2008). Pore-opening mechanism of the nicotinic acetylcholine receptor evinced by proton transfer. Nature Structure and Molecular Biology 15, 389-396.

Cymes, G. D., Ni, Y. \& Grosman, C. (2005). Probing ionchannel pores one proton at a time. Nature 438, 975-980.

Dacosta, C. J. \& Baenziger, J. E. (2009). A lipiddependent uncoupled conformation of the acetylcholine receptor. Journal of Biological Chemistry 284, 1781917825.

Dahan, D. S., Dibas, M. I., Petersson, E. J., Auyeung, V. C., Chanda, B., Bezanilla, F., Dougherty, D. A. \& Lester, H. A. (2004). A fluorophore attached to nicotinic acetylcholine receptor $\beta$ M2 detects productive binding of agonist to the alpha delta site. Proceedings of the National Academy of Sciences USA 101, 10195-10200.

Dang, H., England, P. M., Farivar, S. S., Dougherty, D. A. \& Lester, H. A. (2000). Probing the role of a conserved M1 proline residue in 5- hydroxytryptamine(3) receptor gating. Molecular Pharmacology 57, $1114-1122$.

Davies, P. A., Pistis, M., Hanna, M. C., Peters, J. A., Lambert, J. J., Hales, T. G. \& Kirkness, E. F. (1999). The $5-\mathrm{HT}_{3} \mathrm{~B}$ subunit is a major determinant of serotonin-receptor function. Nature 397, 359-363.

Davies, P. A., Wang, W., Hales, T. G. \& Kirkness, E. F. (2002). A novel class of ligand-gated ion channel is activated by $\mathrm{Zn}^{2+}$. Journal of Biological Chemistry 278, 712-717.

De Planque, M. R., Rijkers, D. T., Liskamp, R. M. \& Separovic, F. (2004). The $\alpha$ M1 transmembrane segment of the nicotinic acetylcholine receptor interacts strongly with model membranes. Magnetic Resonance Chemistry 42, 148-154.

De Rosa, M. J., Rayes, D., Spitzmaul, G. \& Bouzat, C. (2002). Nicotinic receptor M3 transmembrane domain: position $8^{\prime}$ contributes to channel gating. Molecular Pharmacology 62, 406-414.

Deane, C. M. \& Lummis, S. C. (2001). The role and predicted propensity of conserved proline residues in the 5- $\mathrm{HT}_{3}$ receptor. Journal of Biological Chemistry 276, 37962-37966.

Deeb, T. Z., Carland, J. E., Cooper, M. A., Livesey, M. R., Lambert, J. J., Peters, J. A. \& Hales, T. G. (2007). Dynamic modification of a mutant cytoplasmic cysteine residue modulates the conductance of the human $5-\mathrm{HT}_{3} \mathrm{~A}$ receptor. Journal of Biological Chemistry 282, 6172-6182.

Dellisanti, C. D., Yao, Y., Stroud, J. C., Wang, Z. Z. \& Chen, L. (2007). Crystal structure of the extracellular domain of $\mathrm{nAChR} \alpha 1$ bound to $\alpha$-bungarotoxin at 1.94 Å resolution. Nature Neuroscience 10, 953-962.

Demuro, A. \& Parker, I. (2005). "Optical patch-clamping": single-channel recording by imaging $\mathrm{Ca}^{2+}$ flux through individual muscle acetylcholine receptor channels. Journal of General Physiology 126, 179-192.

Derkach, V., Surprenant, A. \& North, R. A. (1989). 5$\mathrm{HT}_{3}$ receptors are membrane ion channels. Nature 339, 706-709.

Dougherty, D. A. (2008). Cys-loop neuroreceptors: structure to the rescue? Chemical Reviews 108, 16421653.

Drisdel, R. C., Manzana, E. \& Green, W. N. (2004). The role of palmitoylation in functional expression of nicotinic $\alpha 7$ receptors. Journal of Neuroscience 24, 10502 10510.

Drisdel, R. C., Sharp, D., Henderson, T., Hales, T. G. \& Green, W. N. (2008). High affinity binding of epibatidine to serotonin type 3 receptors. Journal of Biological Chemistry 283, 9659-9665.

Dubin, A. E., Huvar, R. D., Andrea, M. R., Pyati, J., Zhu, J. Y., Joy, K. C., Wilson, S. J., Galindo, J. E., Glass, C. A., Luo, L., Jackson, M. R., Lovenberg, T. W. \& ErLander, M. G. (1999). The pharmacological and functional characteristics of the serotonin $5-\mathrm{HT}_{3} \mathrm{~A}$ receptor are specifically modified by a $5-\mathrm{HT}_{3} \mathrm{~B}$ receptor subunit. Journal of Biological Chemistry 274, 30799-30810.

Dunne, E. L., Hosie, A. M., Wooltorton, J. R., Duguid, I. C., Harvey, K., Moss, S. J., Harvey, R. J. \& Smart, T. G. (2002). An N-terminal histidine regulates $\mathrm{Zn}^{2+}$ inhibition on the murine $\mathrm{GABA}_{\mathrm{A}}$ receptor $\beta 3$ subunit. British Journal of Pharmacology 137, 29-38. 
Eddins, D., Lyford, L. K., Lee, J. W., Desai, S. A. \& Rosenberg, R. L. (2002a). Permeant but not impermeant divalent cations enhance activation of nondesensitizing $\alpha 7$ nicotinic receptors. American Journal of Physiology - Cell Physiology 282, C796-C804.

Eddins, D., Sproul, A. D., Lyford, L. K., Mclaughlin, J. T. \& Rosenberg, R. L. (2002b). Glutamate 172, essential for modulation of $\mathrm{L} 247 \mathrm{~T}$ a $\alpha 7 \mathrm{ACh}$ receptors by $\mathrm{Ca}^{2+}$, lines the extracellular vestibule. American Journal of Physiology - Cell Physiology 283, C1454-1460.

Edelstein, S. J., SchaAd, O., Henry, E., Bertrand, D. \& Changeux, J. P. (1996). A kinetic mechanism for nicotinic acetylcholine receptors based on multiple allosteric transitions. Biological Cybernetics 75, 361-379.

Eiselé, J.-L., Bertrand, S., Galzi, J.-L., DevillersThiéry, A., Changeux, J.-P. \& Bertrand, D. (1993). Chimaeric nicotinic-serotonergic receptor combines distinct ligand binding and channel specificities. Nature 366, 479-483.

Emerit, M. B., Doucet, E., Darmon, M. \& Hamon, M. (2002). Native and cloned $5-\mathrm{HT}_{3} \mathrm{AS}$ receptors are anchored to F-actin in clonal cells and neurons. Molecular and Cellular Neuroscience 20, 110-124.

Engblom, A. C., Carlson, B. X., Ollsen, R. W., Schousboe, A. \& Kristiansen, U. (2002). Point mutation in the first transmembrane region of the $\beta 2$ subunit of the $\mathrm{GABA}_{\mathrm{A}}$ receptor alters desensitization kinetics of GABA and anesthetic-induced channel gating. Journal of Biological Chemistry 277, 17438-17447.

England, P. M., Zhang, Y., Dougherty, D. A. \& Lester, H. A. (1999). Backbone mutations in transmembrane domains of a ligand-gated ion channel: implications for the mechanism of gating. Cell 96, 89-98.

Enz, R. \& CutTing, G. R. (1999). GABAC receptor tho subunits are heterogeneously expressed in the human CNS and form homo- and heterooligomers with distinct physical properties. European Journal of Neuroscience 11, 41-50.

Everitt, A. B., Seymour, V. A., Curmi, J., Laver, D. R., Gage, P. W. \& Tierney, M. L. (2009). Protein interactions involving the $\gamma 2$ large cytoplasmic loop of $\mathrm{GABA}_{\mathrm{A}}$ receptors modulate conductance. FASEB Journal 23, 4361-4369.

Faghih, R., Gopalakrishnan, M. \& Briggs, C. A. (2008). Allosteric modulators of the $\alpha 7$ nicotinic acetylcholine receptor. Journal of Medicinal Chemistry 51, 701-712.

Fatima-Shad, K. \& Barry, P. H. (1993). Anion permeation in GABA- and glycine-gated channels of mammalian cultured hippocampal neurons. Proceedings of the Royal Society of London, Series B. Biological Science 253, 69-75.

Filatov, G. N. \& White, M. M. (1995). The role of conserved leucines in the M2 domain of the acetylcholine receptor in channel gating. Molecular Pharmacology 48, 379-384.
Filippova, N., Sedelnikova, A., Zong, Y., Fortinberry, H. \& Weiss, D. S. (2000). Regulation of recombinant $\mathrm{GABA}_{\mathrm{A}}$ and $\mathrm{GABA}_{\mathrm{C}}$ receptors by protein kinase C. Molecular Pharmacology 57, 847-856.

Filippova, N., Wotring, V. E. \& Weiss, D. S. (2004). Evidence that the TM1-TM2 to the $\rho 1$ GABA receptor pore. Journal of Biological Chemistry 279, 20906-20914.

Finer-Moore, J. \& Stroud, R. M. (1984). Amphipathic analysis and possible formation of the ion channel in an acetylcholine receptor. Proceedings of the National Academy of Sciences USA 81, 155-159.

Fisher, J. L. (2002). A histidine residue in the extracellular $\mathrm{N}$-terminal domain of the $\mathrm{GABA}_{\mathrm{A}}$ receptor $\alpha 5$ subunit regulates sensitivity to inhibition by zinc. Neuropharmacology 42, 922-928.

Fisher, J. L. \& Macdonald, R. L. (1998). The role of an alpha subtype M2-M3 His in regulating inhibition of $\mathrm{GABA}_{\mathrm{A}}$ receptor current by zinc and other divalent cations. Journal of Neuroscience 18, 2944-2953.

Flood, P., Ramirez-Latorre, J. \& Role, L. (1997). $\alpha 4 \beta 2$ neuronal nicotinic acetylcholine receptors in the central nervous system are inhibited by isoflurane and propofol, but $\alpha 7$-type nicotinic acetylcholine receptors are unaffected. Anesthesiology 86, 859-865.

Fludzinski, P., Evrard, D. A., Bloomquist, W. E., Lacefield, W. B., Pfeifer, W., Jones, N. D., Deeter, J. B. \& Cohen, M. L. (1987). Indazoles as indole bioisosteres: synthesis and evaluation of the tropanyl ester and amide of indazole-3-carboxylate as antagonists at the serotonin $5 \mathrm{HT}_{3}$ receptor. Journal of Medicinal Chemistry 30, 1535-1537.

Fujimoto, K., Yoshimura, Y., Ihara, M., Matsuda, K., Takeuchi, Y., Aoki, T. \& Ide, T. (2008). Cy33-acylcholine: a fluorescent analogue of acetylcholine for single molecule detection. Bioorganic and Medicinal Chemistry Letters 18, 1106-1109.

Gaimarri, A., Moretti, M., Riganti, L., Zanardi, A., Clementi, F. \& GotTi, C. (2007). Regulation of neuronal nicotinic receptor traffic and expression. Brain Research Reviews 55, 134-143.

Gallivan, J. P. \& Dougherty, D. A. (1999). Cation- $\pi$ interactions in structural biology. Proceedings of the National Academy of Sciences USA 96, 9459-9464.

Galzi, J. L., Devillers-Thiery, A., Hussy, N., Bertrand, S., Changeux, J. P. \& Bertrand, D. (1992). Mutations in the channel domain of a neuronal nicotinic receptor convert ion selectivity from cationic to anionic. Nature 359, 500-505.

Galzi, J. L., Bertrand, S., Corringer, P. J., Changeux, J. P. \& Bertrand, D. (1996). Identification of calcium binding sites that regulate potentiation of a neuronal nicotinic acetylcholine receptor. EMBO Journal 15, 5824-5832.

Gao, F., Mer, G., Tonelli, M., Hansen, S. B., Burghardt, T. P., Taylor, P. \& Sine, S. M. (2006). Solution NMR of acetylcholine binding protein reveals 
agonist-mediated conformational change of the C-loop. Molecular Pharmacology 70, 1230-1235.

GAY, E. A. \& YAKeL, J. L. (2007). Gating of nicotinic ACh receptors; new insights into structural transitions triggered by agonist binding that induce channel opening. Journal of Physiology 584, 727-733.

Gerzanich, V., Wang, F., Kuryatov, A. \& Lindstrom, J. (1998). Alpha 5 subunit alters desensitization, pharmacology, $\mathrm{Ca}^{2+}$ permeability and $\mathrm{Ca}^{2+}$ modulation of human neuronal $\alpha 3$ nicotinic receptors. Journal of Pharmacology and Experimental Therapeutics 286, 311-320.

Gill, C. H., Peters, J. A. \& Lambert, J. J. (1995). An electrophysiological investigation of the properties of a murine recombinant $5-\mathrm{HT}_{3}$ receptor stably expressed in HEK 293 cells. British Journal of Pharmacology 114, 1211-1221.

Gleitsman, K. R., Lester, H. A. \& Dougherty, D. A. (2009). Probing the role of backbone hydrogen bonding in a critical beta sheet of the extracellular domain of a cys-loop receptor. Chembiochem 10, 1385-1391.

Goren, E. N., Reeves, D. C. \& Akabas, M. H. (2004). Loose protein packing around the extracellular half of the $\mathrm{GABA}_{\mathrm{A}}$ receptor $\beta 1$ subunit M2 channel-lining segment. Journal of Biological Chemistry 279, 11198-11205.

Görne-Tschelnokow, U., Strecker, A., Kaduk, C., Naumann, D. \& Hucho, F. (1994). The transmembrane domains of the nicotinic acetylcholine receptor contain $\alpha$-helical and $\beta$ structures. EMBO Journal 13, 338-341.

Gotti, C., Moretti, M., Gaimarri, A., Zanardi, A., Clementi, F. \& Zoli, M. (2007). Heterogeneity and complexity of native brain nicotinic receptors. Biochemical Pharmacology 74, 1102-1111.

Grailhe, R., De Carvalho, L. P., Paas, Y., Le Poupon, C., Soudant, M., Bregestovski, P., Changeux, J. P. \& Corringer, P. J. (2004). Distinct subcellular targeting of fluorescent nicotinic $\alpha 3 \beta 4$ and serotoninergic $5-\mathrm{HT}_{3} \mathrm{~A}$ receptors in hippocampal neurons. European Journal of Neuroscience 19, 855-862.

Green, T., Stauffer, K. A. \& Lummis, S. C. (1995). Expression of recombinant homo-oligomeric 5hydroxytryptamine3 receptors provides new insights into their maturation and structure. Journal of Biological Chemistry 270, 6056-6061.

Greenfield, Jr., L. J., Zaman, S. H., Sutherland, M. L., Lummis, S. C., Niemeyer, M. I., Barnard, E. A. \& Macdonald, R. L. (2002). Mutation of the $\mathrm{GABA}_{\mathrm{A}}$ receptor M1 transmembrane proline increases GABA affinity and reduces barbiturate enhancement. Neuropharmacology 42, 502-521.

Gronlien, J.H., Hakerud, M., Ween, H., ThorinHagene, K., Briggs, C. A., Gopalakrishnan, M. \& Malysz, J. (2007). Distinct profiles of $\alpha 7 \mathrm{nAChR}$ positive allosteric modulation revealed by structurally diverse chemotypes. Molecular Pharmacology 72, 715-724.

Grosman, C., Salamone, F. N., Sine, S. M. \& Auerbach, A. (2000a). The extracellular linker of muscle acetylcholine receptor channels is a gating control element. Journal of General Physiology 116, 327-340.

Grosman, C., Zhou, M. \& Auerbach, A. (2000b). Mapping the conformational wave of acetylcholine receptor channel gating. Nature 403(6771), 773-776.

Grutter, T., De Carvalho, L. P., Dufresne, V., Taly, A., Edelstein, S. J. \& Changeux, J. P. (2005a). Molecular tuning of fast gating in pentameric ligand-gated ion channels. Proceedings of the National Academy of Sciences USA 102, 18207-18212.

Grutter, T., Prado De Carvalho, L., Virginie, D., Taly, A., Fischer, M. \& Changeux, J. P. (2005b). A chimera encoding the fusion of an acetylcholine-binding protein to an ion channel is stabilized in a state close to the desensitized form of ligand-gated ion channels. Comptes Rendus Biologies 328, 223-234.

Gunthorpe, M. J. \& Lummis, S. C. R. (2001). Conversion of the ion selectivity of the $5-\mathrm{HT}_{3} \mathrm{~A}$ receptor from cationic to anionic reveals a conserved feature of the ligand-gated ion channel superfamily. Journal of Biological Chemistry 276, 21990.

Gurley, D. A. \& Lanthorn, T. H. (1998). Nicotinic agonists competitively antagonize serotonin at mouse 5$\mathrm{HT}_{3}$ receptors expressed in Xenopus oocytes. Neuroscience Letters 247, 107-110.

Guzman, G. R., Santiago, J., Ricardo, A., MartiArbona, R., Rojas, L. V. \& Lasalde-Dominicci, J. A. (2003). Tryptophan scanning mutagenesis in the $\alpha$ M3 transmembrane domain of the Torpedo californica acetylcholine receptor: functional and structural implications. Biochemistry 42, 12243-12250.

Haeger, S., Kuzmin, D., Detro-Dassen, S., Lang, N., Kilb, M., Tsetlin, V., Betz, H., Laube, B. \& Schmalzing, G. (2010). An intramembrane aromatic network determines pentameric assembly of Cys-loop receptors. Nature Structural and Molecular Biology 17, 90-98.

Hales, T. G., Dunlop, J. I., Deeb, T. Z., Carland, J. E., Kelley, S. P., Lambert, J. J. \& Peters, J. A. (2006). Common determinants of single channel conductance within the large cytoplasmic loop of 5-hydroxytryptamine type 3 and $\alpha 4 \beta 2$ nicotinic acetylcholine receptors. Journal of Biological Chemistry 281, 8062-8071.

Hanek, A. P., Lester, H. A. \& Dougherty, D. A. (2010). Photochemical proteolysis of an unstructured linker of the GABAAR extracellular domain prevents GABA but not pentobarbital activation. Molecular Pharmacology 78(1), 29-35.

Hansen, S. B., Sulzenbacher, G., Huxford, T., Marchot, P., Taylor, P. \& Bourne, Y. (2005). Structures of Aplysia AChBP complexes with nicotinic agonists and antagonists reveal distinctive binding interfaces and conformations. EMBO Journal 24, 3635-3646.

Hansen, S. B. \& Taylor, P. (2007). Galanthamine and non-competitive inhibitor binding to ACh-binding protein: evidence for a binding site on non-alpha-subunit 
interfaces of heteromeric neuronal nicotinic receptors. Journal of Molecular Biology 369, 895-901.

Hanson, S. M. \& CZajKowski, C. (2008). Structural mechanisms underlying benzodiazepine modulation of the $\mathrm{GABA}_{\mathrm{A}}$ receptor. Journal of Neuroscience 28, 3490-3499.

Hawthorne, R. \& Lynch, J. W. (2006). The molecular pharmacology of the glycine receptor. In Biological and Biophysical Aspects of Ligand-Gated Ion Channel Receptor Superfamilies (Ed. H. R. Arias), pp. 35836-35843. Kerala, India: Research Signpost.

Hibbs, R. E., Sulzenbacher, G., Shi, J., Talley, T. T., Conrod, S., Kem, W. R., Taylor, P., Marchot, P. \& Bourne, Y. (2009). Structural determinants for interaction of partial agonists with acetylcholine binding protein and neuronal $\alpha 7$ nicotinic acetylcholine receptor. Embo Journal 28, 3040-3051.

Hilf, R. J. \& Dutzler, R. (2008). X-ray structure of a prokaryotic pentameric ligand-gated ion channel. Nature 452, 375-379.

Hogg, R. C. \& Bertrand, D. (2007). Partial agonists as therapeutic agents at neuronal nicotinic acetylcholine receptors. Biochemical Pharmacology 73, 459-468.

Hogg, R. C., Raggenbass, M. \& Bertrand, D. (2003). Nicotinic acetylcholine receptors: from structure to brain function. Reviews of Physiology, Biochemistry and Pharmacology 147, 1-46.

Holbrook, J. D., Gill, C. H., Zebda, N., Spencer, J. P., Leyland, R., Rance, K. H., Trinh, H., Balmer, G., Kelly, F. M., Yusaf, S. P., Courtenay, N., Luck, J., Rhodes, A., Modha, S., Moore, S. E., Sanger, G. J. \& Gunthorpe, M. J. (2009). Characterisation of 5-HT3C, 5-HT3D and 5-HT3E receptor subunits: evolution, distribution and function. Journal of Neurochemistry 108, 384-396.

Horenstein, J. \& Akabas, M. H. (1998). Location of a high affinity $\mathrm{Zn}^{2+}$ binding site in the channel of $\alpha 1 \beta 1$ $\mathrm{GABA}_{\mathrm{A}}$ receptors. Molecular Pharmacology 53, 870-877.

Horenstein, J., Wagner, D., Czajkowski, C. \& Akabas, M. (2001). Protein mobility and GABA-induced conformational changes in $\mathrm{GABA}_{\mathrm{A}}$ receptor pore-lining M2 segment. Nature Neuroscience 4, 477-485.

Hosie, A. M., Dunne, E. L., Harvey, R. J. \& Smart, T. G. (2003). Zinc-mediated inhibition of $\mathrm{GABA}_{\mathrm{A}}$ receptors: discrete binding sites underlie subtype specificity. Nature Neuroscience 6, 362-369.

Hovius, R., Schmid, E. L., Tairi, A. P., Blasey, H., Bernard, A. R., Lundstrom, K. \& Vogel, H. (1999). Fluorescence techniques for fundamental and applied studies of membrane protein receptors: the $5-\mathrm{HT}_{3}$ serotonin receptor. Journal of Receptor Signal and Transduction Research 19, 533-545.

Hisiao, B., Mihalak, K. B., Repicky, S. E., Everhart, D., Mederos, A. H., Malhotra, A. \& Luetje, C. W. (2006). Determinants of zinc potentiation on the $\alpha 4$ subunit of neuronal nicotinic receptors. Molecular Pharmacology 69, $27-36$.
Hu, X. Q. \& Lovinger, D. M. (2005). Role of aspartate 298 in mouse 5-HT3A receptor gating and modulation by extracellular $\mathrm{Ca}^{2+}$. Journal of Physiology 568, 381-396.

Hu, X. Q. \& Peoples, R. W. (2008). The $5-\mathrm{HT}_{3} \mathrm{~B}$ subunit confers spontaneous channel opening and altered ligand properties of the $5-\mathrm{HT}_{3}$ receptor. Journal of Biological Chemistry 283, 6826-6831.

Hu, X. Q., Zhang, L., Stewart, R. R. \& Weight, F. F. (2003). Arginine 222 in the pre-transmembrane domain 1 of $5-\mathrm{HT}_{3} \mathrm{~A}$ receptors links agonist binding to channel gating. Journal of biological Chemistry 278, 46583-46589.

Huang, R.-Q., Gonzales, E. B. \& Dillon, G. H. (2006). GABAA receptors: structure, function and modulation. In Biological and Biophysical Aspects of Ligand-Gated Ion Channel Receptor Superfamilies (Ed. H. R. Arias), pp. 171198. Kerala, India: Research Signpost.

Hubbard, P. C. \& Lummis, S. C. (2000). $\mathrm{Zn}^{2+}$ enhancement of the recombinant $5-\mathrm{HT}(3)$ receptor is modulated by divalent cations. European Journal of Pharmacology 394, 189-197.

Hubbard, P. C., Thompson, A. J. \& Lummis, S. C. (2000). Functional differences between splice variants of the murine 5- $\mathrm{HT}_{3} \mathrm{~A}$ receptor: possible role for phosphorylation. Brain Research and Molecular Brain Research 81, 101-108.

Hummer, G., Rasaiah, J. C. \& Noworyta, J. P. (2001). Water conduction through the hydrophobic channel of a carbon nanotube. Nature 414, 188-190.

Hussy, N., Lukas, W. \& Jones, K. A. (1994). Functional properties of a cloned 5-hydroxytryptamine ionotropic receptor subunit: comparison with native mouse receptors. Journal of Physiology 481, 311-323.

Ilegems, E., Pick, H. M., Deluz, C., Kellenberger, S. \& Vogel, H. (2004). Noninvasive imaging of $5-\mathrm{HT}_{3}$ receptor trafficking in live cells: from biosynthesis to endocytosis. Journal of Biological Chemistry 279, 5334653352.

JACKSON, M. B. (1984). Spontaneous openings of the acetylcholine receptor channel. Proceedings of the National Academy of Sciences USA 81, 3901-3904.

JACKsOn, M. B. (1986). Kinetics of unliganded acetylcholine receptor channel gating. Biophysical Journal 49(3), 663-672.

Jansen, M., Bali, M. \& Akabas, M. H. (2008). Modular design of Cys-loop ligand-gated ion channels: functional $5-\mathrm{HT}_{3}$ and GABA $\rho 1$ receptors lacking the large cytoplasmic M3M4 loop. Journal of General Physiology 131, 137-146.

Jensen, A. A., Davies, P. A., Brauner-Osborne, H. \& KRZYWKOwski, K. (2008). 3B but which 3B? And that's just one of the questions: the heterogeneity of human 5-HT(3) receptors. Trends in Pharmacological Science 29, 437-444.

Jensen, M. L., Pedersen, L. N., Timmermann, D. B., Schousboe, A. \& Ahring, P. K. (2005a). Mutational studies using a cation-conducting $\mathrm{GABA}_{\mathrm{A}}$ receptor 
reveal the selectivity determinants of the Cys-loop family of ligand-gated ion channels. Journal of Neurochemistry 92, 962-972.

Jensen, M. L., Schousboe, A. \& Ahring, P. K. (2005b). Charge selectivity of the Cys-loop family of ligand-gated ion channels. Journal of Neurochemistry 92, 217-225.

Jensen, M. L., Timmermann, D. B., Johansen, T. H., Schousboe, A., Varming, T. \& Ahring, P. K. (2002). The $\beta$ subunit determines the ion selectivity of the $\mathrm{GABA}_{\mathrm{A}}$ receptor. Journal of Biological Chemistry 277, 41438-41447.

Jones-Davis, D. M., Song, L., Gallagher, M. J. \& Macdonald, R. L. (2005). Structural determinants of benzodiazepine allosteric regulation of $\mathrm{GABA}_{\mathrm{A}}$ receptor currents. Journal of Neuroscience 25, 8056-8065.

Joshi, P. R., Suryanarayanan, A., Hazai, E., Schulte, M. K., MAKSAY, G. \& BiKadi, Z. (2006). Interactions of granisetron with an agonist-free $5-\mathrm{HT}_{3} \mathrm{~A}$ receptor model. Biochemistry 45, 1099-1105.

Kaneez, F. S. \& White, M. (2004). Patch clamp study of serotonin-gated currents via 5 -HT type 3 receptors by using a novel approach SHAM for receptor channel scanning. Journal of Biomedical Biotechnology 1, 10-15.

Kapur, J. \& Macdonald, R. L. (1997). Rapid seizure-induced reduction of benzodiazepine and $\mathrm{Zn}^{2+}$ sensitivity of hippocampal dentate granule cell $\mathrm{GABA}_{\mathrm{A}}$ receptors. Journal of Neuroscience 17, 7532-7540.

Karlin, A., Holtzman, E., Yodh, N., Lobel, P., Wall, J. \& Hainfeld, J. (1983). The arrangement of the subunits of the acetylcholine receptor of Torpedo californica. Journal of Biological Chemistry 258, 6678-6681.

Kash, T. L., Dizon, M. J., Trudell, J. R. \& Harrison, N. L. (2004). Charged residues in the $\beta 2$ subunit involved in $\mathrm{GABA}_{\mathrm{A}}$ receptor activation. Journal of Biological Chemistry 279, 4887-4893.

Kash, T. L., Jenkins, A., Kelley, J. C., Trudell, J. R. \& Harrison, N. L. (2003). Coupling of agonist binding to channel gating in the $\mathrm{GABA}_{\mathrm{A}}$ receptor. Nature 421, 272-275.

Kelley, S. P., Dunlop, J. I., Kirkness, E. F., Lambert, J. J. \& Peters, J. A. (2003). A cytoplasmic region determines single-channel conductance in $5-\mathrm{HT}_{3}$ receptors. Nature 424, 321-324.

Keramidas, A., Moorhouse, A. J., French, C. R., Schofield, P. R. \& Barry, P. H. (2000). M2 pore mutations convert the glycine receptor channel from being anion- to cation-selective. Biophysical Journal 79, 247-259.

Keramidas, A., Moorhouse, A. J., Pierce, K. D., Schofield, P. R. \& Barry, P. H. (2002). Cationselective mutations in the M2 domain of the inhibitory glycine receptor channel reveal determinants of ioncharge selectivity. Journal of General Physiology 119, 393-410.

Keramidas, A., Moorhouse, A. J., Schofield, P. R. \& BARry, P. H. (2004). Ligand-gated ion channels: mechanisms underlying ion selectivity. Progress in Biophysics and Molecular Biology 86, 161-204.

Kneussel, M. \& Loebrich, S. (2007). Trafficking and synaptic anchoring of ionotropic inhibitory neurotransmitter receptors. Biology of the Cell 99, 297-309.

Konno, T., Busch, C., Von Kitzing, E., Imoto, K., Wang, F., Nakai, J., Mishina, M., Numa, S. \& Sakmann, B. (1991). Rings of anionic amino acids as structural determinants of ion selectivity in the acetylcholine receptor channel. Proceedings of the Royal Society of London B: Biological Science 244, 69-79.

Korpi, E. R., Grunder, G. \& Luddens, H. (2002). Drug interactions at $\mathrm{GABA}_{\mathrm{A}}$ receptors. Progress in Neurobiology 67, 113-159.

Kucken, A. M., Wagner, D. A., Ward, P. R., Teissere, J. A., Bolleau, A. J. \& Czajkowski, C. (2000). Identification of benzodiazepine binding site residues in the $\gamma 2$ subunit of the $\mathrm{GABA}_{\mathrm{A}}$ receptor. Molecular Pharmacology 57, 932-939.

Kusama, T., Wang, J. B., Spivak, C. E. \& Uhl, G. R. (1994). Mutagenesis of the GABA $\rho 1$ receptor alters agonist affinity and channel gating. Neuroreport 5, 1209-1212.

Labarca, C., Nowak, M.W., Zhang, H., Tang, L., Deshpande, P. \& Lester, H. A. (1995). Channel gating governed symmetrically by conserved leucine residues in the M2 domain of nicotinic receptors. Nature 376, 514-516.

Lambert, J. J., Peters, J. A., Hales, T. G. \& Dempster, J. (1989). The properties of $5-\mathrm{HT}_{3}$ receptors in clonal cell lines studied by patch-clamp techniques. British Journal of Pharmacology 97, 27-40.

Lankiewicz, S., Huser, M. B., Heumann, R., Hatt, H. \& Gisselmann, G. (2000). Phosphorylation of the 5hydroxytryptamine $3\left(5-\mathrm{HT}_{3}\right)$ receptor expressed in HEK293 cells. Receptors Channels 7, 9-15.

Lape, R., Colquhoun, D. \& Sivilotti, L. G. (2008). On the nature of partial agonism in the nicotinic receptor superfamily. Nature 454, 722-727.

Lasalde, J. A., Tamamizu, S., Butler, D. H., Vibat, C. R., Hung, B. \& Mcnamee, M. G. (1996). Tryptophan substitutions at the lipid-exposed transmembrane segment M4 of Torpedo californica acetylcholine receptor govern channel gating. Biochemistry 35, 14139-14148.

Law, R. J., Forrest, L. R., Ranatunga, K. M., La Rocca, P., Tieleman, D. P. \& Sansom, M. S. (2000). Structure and dynamics of the pore-lining helix of the nicotinic receptor: MD simulations in water, lipid bilayers, and transbilayer bundles. Proteins 39, 47-55.

Le Novere, N., Grutter, T. \& Changeux, J. P. (2002). Models of the extracellular domain of the nicotinic receptors and of agonist- and $\mathrm{Ca}^{2+}$-binding sites. Proceedings of the National Academy of Sciences USA 99, 3210-3215.

Lee, Y. H., Li, L., Lasalde, J., Rojas, L., Mcnamee, M., Ortiz-Miranda, S. I. \& Pappone, P. (1994). Mutations 
in the M4 domain of Torpedo californica acetylcholine receptor dramatically alter ion channel function. Biophysical Journal 66, 646-653.

Lee, W. Y., Free, C. R. \& Sine, S. M. (2008). Nicotinic receptor interloop proline anchors $\beta 1-\beta 2$ and Cys loops in coupling agonist binding to channel gating. Journal of General Physiology 132, 265-278.

Lee, W. Y., Free, C. R. \& Sine, S. M. (2009). Binding to gating transduction in nicotinic receptors: Cys-loop energetically couples to pre-M1 and M2-M3 regions. Journal of Neuroscience 29, 3189-3199.

LeE, W. Y. \& Sine, S. M. (2005). Principal pathway coupling agonist binding to channel gating in nicotinic receptors. Nature 438, 243-247.

Leite, J. F., Blanton, M. P., Shahgholi, M., Dougherty, D. A. \& Lester, H. A. (2003). Conformationdependent hydrophobic photolabeling of the nicotinic receptor: electrophysiology-coordinated photochemistry and mass spectrometry. Proceedings of the National Academy of Sciences USA 100, 13054-13059.

Leonard, R. J., Labarca, C. G., Charnet, P., Davidson, N. \& Lester, H.A. (1988). Evidence that the M2 membrane-spanning region lines the ion channel pore of the nicotinic receptor. Science 242, 1578-1581.

Lester, H. A. (1992). The permeation pathway of neurotransmitter-gated ion channels. Annual Review of Biophysics and Biomolecular Structure 21, 267-292.

Lewis, T. M., Sivilotti, L. G., Colquhoun, D., Gardiner, R. M., Schoepfer, R. \& Rees, M. (1998). Properties of human glycine receptors containing the hyperekplexia mutation alpha1(K276E), expressed in Xenopus oocytes. Journal of Physiology 507, 25-40.

Li, P., Stimko, E. M. \& Lester, H. A. (2002). Selective elimination of glutamate activation and introduction of fluorescent proteins into a Caenorhabditis elegans chloride channel. FEBS Letters 528, 77-82.

Limapichat, W., Lester, H.A. \& Dougherty, D. A. (2010). Chemical scale studies of the Phe-Pro conserved motif in the Cys loop of Cys loop receptors. Journal of Biolical Chemistry 285, 8976-8984.

Livesey, M. R., Cooper, M. A., Deeb, T. Z., Carland, J. E., Kozuska, J., Hales, T. G., Lambert, J. J. \& Peters, J. A. (2008). Structural determinants of $\mathrm{Ca}^{2+}$ permeability and conduction in the human 5-hydroxytryptamine type 3A receptor. Journal of Biological Chemistry 283, 19301-19313.

Lobitz, N., Gisselmann, G., Нatt, H. \& Wetzel, C. H. (2001). A single amino-acid in the TM1 domain is an important determinant of the desensitization kinetics of recombinant human and guinea pig alpha-homomeric 5-hydroxytryptamine type 3 receptors. Molecular Pharmacology 59, 844-851.

Lobo, I. A., Mascia, M. P., Trudell, J. R. \& Harris, R. A. (2004). Channel gating of the glycine receptor changes accessibility to residues implicated in receptor potentiation by alcohols and anesthetics. Journal of Biological Chemistry 297, 33919-33927.

Lochner, M. \& Lummis, S. C. (2010). Agonists and antagonists bind to an A-A interface in the heteromeric 5HT3AB receptor. Biophysical Journal 98, 1494-1502.

Lopes, C., Pereira, E. F., Wu, H. Q., Purushottamachar, P., Njar, V., Schwarcz, R. \& Albuquerque, E. X. (2007). Competitive antagonism between the nicotinic allosteric potentiating ligand galantamine and kynurenic acid at $\alpha 7$ nicotinic receptors. Journal of Pharmacology and Experimental Therapentics 322, 48-58.

Lugovskoy, A. A., Maslennikov, I. V., Utkin, Y. N., Tsetlin, V. I., Cohen, J. B. \& Arseniev, A. S. (1998). Spatial structure of the M3 transmembrane segment of the nicotinic acetylcholine receptor $\alpha$ subunit. European Journal of Biochemistry 255, 455-461.

Lummis, S. C., Beene, D. L., Harrison, N. J., Lester, H. A. \& Dougherty, D. A. (2005a). A cation $-\pi$ binding interaction with a tyrosine in the binding site of the $\mathrm{GABA}_{\mathrm{C}}$ receptor. Chemistry \&l Biology 12, 993-997.

Lummis, S. C., Beene, D. L., Lee, L. W., Lester, H. A., Broadhurst, R. W. \& Dougherty, D. A. (2005b). Cistrans isomerization at a proline opens the pore of a neurotransmitter-gated ion channel. Nature 438, 248-252.

LyNCH, J. W. (2004). Molecular structure and function of the glycine receptor chloride channel. Physiological Reviews 84, 1051-1095.

Lynch, J. W. (2009). Native glycine receptor subtypes and their physiological roles. Neuropharmacology 56, 303-309.

Lynch, J. W., Rajendra, S., Pierce, K. D., Handford, C. A., Barry, P. H. \& Schofield, P. R. (1997). Identification of intracellular and extracellular domains mediating signal transduction in the inhibitory glycine receptor chloride channel. EMBO Journal 16, 110-120.

Lynch, J. W., Han, N. L., Haddrill, J., Pierce, K. D. \& Schofield, P. R. (2001). The surface accessibility of the glycine receptor M2-M3 loop is increased in the channel open state. Journal of Neuroscience 21, 2589-2599.

Ma, D., Liv, Z., Li, L., TANG, P. \& Xu, Y. (2005). Structure and dynamics of the second and third transmembrane domains of human glycine receptor. Biochemistry 44, 8790-8800.

Machu, T. K. \& Harris, R. A. (1994). Alcohols and anesthetics enhance the function of 5-hydroxytryptamine3 receptors expressed in Xenopus laevis oocytes. Journal of Pharmacology and Experimental Therapeutics 271, 898-905.

Macor, J. E., Gurley, D., Lanthorn, T., Loch, J., Mack, R. A., Mullen, G., Tran, O., Wright, N. \& Gordon, J. C. (2001). The 5- $\mathrm{HT}_{3}$ antagonist tropisetron (ICS 205-930) is a potent and selective alpha7 nicotinic receptor partial agonist. Bioorganic and Medicinal Chemical Letters 11, 319-321.

Maksay, G., Bikadi, Z. \& Simonyi, M. (2003). Binding interactions of antagonists with 5-hydroxytryptamine3A 
receptor models. Journal of Receptor Signal and Transduction Research 23, 255-270.

Malone, H. M., Peters, J. A. \& Lambert, J. J. (1991). Physiological and pharmacological properties of 5 $\mathrm{HT}_{3}$ receptors - a patch-clamp study. Neuropeptides 19(Suppl), 25-30.

Mcdonald, B. J. \& Moss, S. J. (1994). Differential phosphorylation of intracellular domains of $\mathrm{GABA}_{\mathrm{A}}$ receptor subunits by calcium/calmodulin type 2-dependent protein kinase and cGMP-dependent protein kinase. Journal of Biological Chemistry 269, 18111-18117.

Mcdonald, B. J. \& Moss, S. J. (1997). Conserved phosphorylation of the intracellular domains of $\mathrm{GABA}_{\mathrm{A}}$ receptor $\beta 2$ and $\beta 3$ subunits by cAMP-dependent protein kinase, cGMP-dependent protein kinase protein kinase $\mathrm{C}$ and $\mathrm{Ca}^{2+} /$ calmodulin type II-dependent protein kinase. Neuropharmacology 36, 1377-1385.

Mckernan, R. M., Farrar, S., Collins, I., Emms, F., Asuni, A., Quirk, K. \& Broughton, H. (1998). Photoaffinity labeling of the benzodiazepine binding site of $\alpha 1 \beta 3 \gamma 2$ $\mathrm{GABA}_{\mathrm{A}}$ receptors with flunitrazepam identifies a subset of ligands that interact directly with His102 of the alpha subunit and predicts orientation of these within the benzodiazepine pharmacophore. Molecular Pharmacology 54, 33-43.

Melis, C., Lummis, S. C. \& Molteni, C. (2008). Molecular dynamics simulations of GABA binding to the $\mathrm{GABA}_{\mathrm{C}}$ receptor: the role of Arg104. Biophysical Journal 95, 4115-4123.

Melzer, N., Villmann, C., Becker, K., Harvey, K., Harvey, R. J., Vogel, N., Kluck, C. J., Kneussel, M. \& BECKER, C. M. (2010). Multifunctional basic motif in the glycine receptor intracellular domain induces subunitspecific sorting. Journal of Biological Chemistry 285, 3730-3739.

Menard, C., Horvitz, H. R., Cannon, S. (2005). Chimeric mutations in the M2 segment of the 5-hydroxytryptamine-gated chloride channel MOD-1 define a minimal determinant of anion/cation permeability. Journal of Biological Chemistry 280, 27502-27507.

Methot, N., Mccarthy, M. P. \& Baenziger, J. E. (1994). Secondary structure of the nicotinic acetylcholine receptor: implications for structural models of a ligandgated ion channel. Biochemistry 33, 7709-7717.

Minic, S. J., Whiting, P. J., Klein, R. L., Wafford, K. A. \& Harris, R. A. (1994). A single amino acid of the human $\mathrm{GABA}_{\mathrm{A}}$ receptor $\gamma 2$ subunit determines benzodiazepine efficacy. Journal of Biological Chemistry 269, 32768-32773.

Millar, N. S. (2008). RIC-3: a nicotinic acetylcholine receptor chaperone. British Journal of Pharmacology 153(Suppl. 1), S177-183.

Millar, N. S. \& Harkness, P. C. (2008). Assembly and trafficking of nicotinic acetylcholine receptors. Molecular Membrane Biology 25, 279-292.
Miller, J. C., Silverman, S. K., England, P. M., Dougherty, D. A. \& Lester, H. A. (1998). Flash decaging of tyrosine sidechains in an ion channel. Neuron 20, 619-624.

Millar, N. S. \& GotTi, C. (2009). Diversity of vertebrate nicotinic acetylcholine receptors. Neuropharmacology 56, 237-246.

Miyazawa, A., Fujiyoshi, Y., Stowell, M. \& Unwin, N. (1999). Nicotinic acetylcholine receptor at $4.6 \AA$ resolution: transverse tunnels in the channel wall. Journal of Molecular Biology 288, 765-786.

Miyazawa, A., Fujiyoshi, Y. \& Unwin, N. (2003). Structure and gating mechanism of the acetylcholine receptor pore. Nature 424, 949-955.

Mochizuki, S., Watanabe, T., Miyake, A., Saito, M. \& Furuichi, K. (2000). Cloning, expression, and characterization of ferret $5-\mathrm{HT}_{3}$ receptor subunit. European Journal of Pharmacology 399, 97-106.

Moorhouse, A. J., Keramidas, A., Zaykin, A., Schofield, P. R. \& Barry, P. H. (2002). Single channel analysis of conductance and rectification in cation-selective, mutant glycine receptor channels. Journal of General Physiology 119, 411-425.

Moroni, M. \& Bermudez, I. (2006). Stoichiometry and pharmacology of two human alpha4beta2 nicotinic receptor types. Journal of Molecular Neuroscience 30, 95-96.

Moroni, M., Zwart, R., Sher, E., Cassels, B. K. \& Bermudez, I. (2006). $\alpha 4 \beta 2$ nicotinic receptors with high and low acetylcholine sensitivity: pharmacology, stoichiometry, and sensitivity to long-term exposure to nicotine. Molecular Pharmacology 70, 755-768.

Moss, S. J., Doherty, C. A. \& Huganir, R. L. (1992). Identification of the cAMP-dependent protein kinase and protein kinase $\mathrm{C}$ phosphorylation sites within the major intracellular domains of the $\beta 1, \gamma 2 \mathrm{~S}$, and $\gamma 2 \mathrm{~L}$ subunits of the $\mathrm{GABA}_{\mathrm{A}}$ receptor. Journal of Biological Chemistry 267, 14470-14476.

Moss, S. J., Mcdonald, B. J., Rudhard, Y. \& Schoepfer, R. (1996). Phosphorylation of the predicted major intracellular domains of the rat and chick neuronal nicotinic acetylcholine receptor $\alpha 7$ subunit by cAMPdependent protein kinase. Neuropharmacology 35, 1023-1028.

Mounsey, K. E., Dent, J. A., Holt, D. C., Mccarthy, J., Currie, B. J. \& Walton, S. F. (2007). Molecular characterisation of a $\mathrm{pH}$-gated chloride channel from Sarcoptes scabiei. Invertebrate Neuroscience 7, 149-156.

Mu, T. W., Lester, H. A. \& Dougherty, D. A. (2003). Different binding orientations for the same agonist at homologous receptors: a lock and key or a simple wedge? Journal of the American Chemical Society 125, 6850-6851.

Muroi, Y., Czajkowski, C. \& Jackson, M. B. (2006). Local and global ligand-induced changes in the structure of the $\mathrm{GABA}_{\mathrm{A}}$ receptor. Biochemistry 45, 7013-7022. 
Nakazawa, K., Akiyama, T. \& Inoue, K. (1995). Block by 5-hydroxytryptamine of neuronal acetylcholine receptor channels expressed in Xenopus oocytes. Cellular and Molecular Neurobiology 15, 495-500.

Nass, M. M., Lester, H. A. \& Krouse, M. E. (1978). Response of acetylcholine receptors to photoisomerizations of bound agonist molecules. Biophysical Journal 24, 135-160.

Navedo, M., Nieves, M., Rojas, L. \& Lasalde-Dominicci, J. A. (2004). Tryptophan substitutions reveal the role of nicotinic acetylcholine receptor $\alpha$-TM3 domain in channel gating: differences between Torpedo and muscletype AChR. Biochemistry 43, 78-84.

Nevin, S. T., Cromer, B. A., Haddrill, J. L., Morton, C. J., Parker, M. W. \& Lynch, J. W. (2003). Insights into the structural basis for zinc inhibition of the glycine receptor. Journal of Biological Chemistry 278, 28985-28992.

Ng, H. J., Whittemore, E. R., Tran, M. B., Hogenkamp, D. J., Broide, R. S., Johnstone, T. B., Zheng, L., Stevens, K. E. \& Gee, K. W. (2007). Nootropic $\alpha 7$ nicotinic receptor allosteric modulator derived from $\mathrm{GABA}_{\mathrm{A}}$ receptor modulators. Proceedings of the National Academy of Sciences USA 104, 8059-8064.

Niemeyer, M. I. \& Lummis, S. C. (2001). The role of the agonist binding site in $\mathrm{Ca}(2+)$ inhibition of the recombinant $5-\mathrm{HT}_{3} \mathrm{~A}$ receptor. European Journal of Pharmacology 428, 153-161.

Niesler, B., Frank, B., Kapeller, J. \& Rappold, G. A. (2003). Cloning, physical mapping and expression analysis of the human $5-\mathrm{HT}_{3}$ serotonin receptor-like genes HTR3C, HTR3D and HTR3E. Gene 310, 101-111.

Niesler, B., Walstab, J., Combrink, S., Moeller, D., Kapeller, J., Rietdorf, J., Boenisch, H., Goethert, M., Rappold, G. \& Bruess, M. (2007). Characterization of the novel human serotonin receptor subunits 5HT3C, 5- HT3D and 5-HT3E. Molecular Pharmacology 72, 8-17.

Nishizaki, T. \& IKeuchi, Y. (1995). Activation of endogenous protein kinase $\mathrm{C}$ enhances currents through $\alpha 1$ and $\alpha 2$ glycine receptor channels. Brain Research 687, 214-216.

Nishizaki, T. \& Sumikawa, K. (1998). Effects of PKC and PKA phosphorylation on desensitization of nicotinic acetylcholine receptors. Brain Research 812, 242-245.

Noam, Y., Wadman, W. J. \& Van Hooft, J. A. (2008). On the voltage-dependent $\mathrm{Ca}^{2+}$ block of serotonin $5-\mathrm{HT}_{3}$ receptors: a critical role of intracellular phosphates. Journal of Physiology 586, 3629-3638.

Noda, M., Takahashi, H., Tanabe, T., Toyosato, M., Furutani, Y., Hirose, T., Asai, M., Inayama, S., Miyata, T. \& Numa, S. (1982). Primary structure of $\alpha$-subunit precursor of Torpedo californica acetylcholine receptor deduced from cDNA sequence. Nature 299, 793-797.
Nury, H., Bocquet, N., Le Poupon, C., Raynal, B., Haouz, A., Corringer, P. J. \& Delarue, M. 2009. Crystal structure of the extracellular domain of a bacterial ligand-gated ion channel. Journal of Molecular Biology 395, 1114-1127.

O'shea, S. M. \& Harrison, N. L. (2000). Arg-274 and Leu277 of the $\mathrm{GABA}_{\mathrm{A}}$ receptor $\alpha 2$ subunit define agonist efficacy and potency. Journal of Biological Chemistry 275, 22764-22768.

Olden, L., Pettersson, I., Hemmingsen, L., Adolph, H. W. \& Jorgensen, F. S. (2004a). Docking and scoring of metallo-beta-lactamases inhibitors. Journal of Computer Aided Molecular Design 18, 287-302.

Olsen, R. W. \& Sieghart, W. (2009). GABA A receptors: subtypes provide diversity of function and pharmacology. Neuropharmacology 56, 141-148.

Olsen, R. W., Chang, C. S., Li, G., Hanchar, H. J. \& Wallner, M. (2004b). Fishing for allosteric sites on $\mathrm{GABA}_{\mathrm{A}}$ receptors. Biochemistry and Pharmacology 68, 1675-1684.

Ortiz-Miranda, S. I., Lasalde, J. A., Pappone, P. A. \& Mcnamee, M. G. (1997). Mutations in the M4 domain of the Torpedo californica nicotinic acetylcholine receptor alter channel opening and closing. Journal of Membrane Biology 158, 17-30.

Padgett, C. L., Hanek, A. P., Lester, H. A., Dougherty, D. A. \& Lummis, S. C. (2007). Unnatural amino acid mutagenesis of the $\mathrm{GABA}_{\mathrm{A}}$ receptor binding site residues reveals a novel cation- $\pi$ interaction between GABA and beta 2Tyr97. Journal of Neuroscience 27, 886-892.

Padgett, C. L. \& Lummis, S. C. (2008). The F-loop of the $\mathrm{GABA}_{\mathrm{A}}$ receptor $\gamma 2$ subunit contributes to benzodiazepine modulation. Journal of Biological Chemistry 283, 2702-2708.

Panicker, S., Cruz, H., Arrabit, C. \& Slesinger, P. A. (2002). Evidence for a centrally located gate in the pore of a serotonin-gated ion channel. Journal of Neuroscience 22, 1629-1639.

Panicker, S., Cruz, H., Arrabit, C., Suen, K. F. \& Slesinger, P. A. (2004). Minimal structural rearrangement of the cytoplasmic pore during activation of the 5- $\mathrm{HT}_{3} \mathrm{~A}$ receptor. Journal of Biological Chemistry 279, 28149-28158.

Pantoja, R., Rodriguez, E. A., Dibas, M. I., Dougherty, D. A. \& Lester, H. A. (2009). Single-molecule imaging of a fluorescent unnatural amino acid incorporated into nicotinic receptors. Biophysical Journal 96, 226-237.

Peters, J. A., Kelley, S. P., Dunlop, J. I., Kirkness, E. F., Hales, T. G. \& Lambert, J. J. (2004). The 5-hydroxytryptamine type $3\left(5-\mathrm{HT}_{3}\right)$ receptor reveals a novel determinant of single-channel conductance. Biochemical Society Transactions 32, 547-552.

Peters, J. A., Hales, T. G. \& Lambert, J. J. (2005). Molecular determinants of single-channel conductance and ion selectivity in the Cys-loop family: insights from 
the 5- $\mathrm{HT}_{3}$ receptor. Trends in Pharmacological Science 26, 587-594.

Peters, J. A., Cooper, M. A., Carland, J. E., Livesey, M. R., Hales, T. G. \& Lambert, J. J. (2010). Novel structural determinants of single channel conductance and ion selectivity in 5-hydroxytryptamine type 3 and nicotinic acetylcholine receptors. Journal of Physiology 588, 587-595.

Pless, S. A., Dibas, M. I., Lester, H. A. \& Lynch, J. W. (2007). Conformational variability of the glycine receptor M2 domain in response to activation by different agonists. Journal of Biological Chemistry 282, 36057-36067.

Pless, S. A. \& Lynch, J. W. (2008). Illuminating the structure and function of Cys-loop receptors. Clinical and Experimental Pharmacology and Physiology 35, 1137-1142.

Pless, S. A. \& Lynch, J. W. (2009). Distinct conformational changes in activated agonist-bound and agonist-free glycine receptor subunits. Journal of Neurochemistry 108, 1585-1594.

Pless, S. A., Millen, K. S., Hanek, A. P., Lynch, J. W., Lester, H. A., Lummis, S. C. \& Dougherty, D. A. (2008). A cation-pi interaction in the binding site of the glycine receptor is mediated by a phenylalanine residue. Journal of Neuroscience 28, 10937-10942.

Price, K. L., Millen, K. S. \& Lummis, S. C. (2007). Transducing agonist binding to channel gating involves different interactions in $5-\mathrm{HT}_{3}$ and $\mathrm{GABA}_{\mathrm{C}}$ receptors. Journal of Biological Chemistry 282, 25623-25630.

Price, K. L., Bower, K. S., Thompson, A. J., Lester, H. A., Dougherty, D. A. \& Lummis, S. C. (2008). A hydrogen bond in loop A is critical for the binding and function of the $5-\mathrm{HT}_{3}$ receptor. Biochemistry 47, 6370-6377.

Purohit, P., Mitra, A. \& Auerbach, A. (2007). A stepwise mechanism for acetylcholine receptor channel gating. Nature 446, 930-933.

Quirk, P. L., Rao, S., Roth, B. L. \& Siegel, R. E. (2004). Three putative $\mathrm{N}$-glycosylation sites within the murine $5-\mathrm{HT}_{3} \mathrm{~A}$ receptor sequence affect plasma membrane targeting, ligand binding, and calcium influx in heterologous mammalian cells. Journal of Neuroscience Research 77, 498-506.

Rajendra, S., Lynch, J. W., Pierce, K. D., French, C. R., Barry, P. H. \& Schofield, P. R. (1995). Mutation of an arginine residue in the human glycine receptor transforms $\beta$-alanine and taurine from agonists into competitive antagonists. Neuron 14, 169-175.

Ranganathan, R., Cannon, S. C. \& Horvitz, H. R. (2000). MOD-1 is a serotonin-gated chloride channel that modulates locomotory behaviour in C. elegans. Nature 408(6811), 470-475.

Rayes, D., De Rosa, M. J., Sine, S. M. \& Bouzat, C. (2009). Number and locations of agonist binding sites required to activate homomeric Cys-loop receptors. Journal of Neuroscience 29, 6022-6032.
Reeves, D. C. \& Lummis, S. C. (2002). The molecular basis of the structure and function of the $5-\mathrm{HT}_{3}$ receptor: a model ligand-gated ion channel. Molecular membrane Biology 19, 11-26.

Reeves, D. C., Goren, E. N., Akabas, M. H. \& Lummis, S. C. (2001). Structural and electrostatic properties of the $5-\mathrm{HT}_{3}$ receptor pore revealed by substituted cysteine accessibility mutagenesis. Journal of Biological Chemistry 276, 42035-42042.

Reeves, D. C., Sayed, M. F., Chau, P. L., Price, K. L. \& Lummis, S. C. (2003). Prediction of $5-\mathrm{HT}_{3}$ receptor agonist-binding residues using homology modeling. Biophysical Journal 84, 2338-2344.

Roe, D. C. \& Kuntz, I. D. (1995). BUILDER v.2: improving the chemistry of a de novo design strategy. Journal of Computer Aided Molecular Design 9, 269-282.

Romanelli, M. N., Gratteri, P., Guandalini, L., Martini, E., Bonaccini, C. \& Gualtieri, F. (2007). Central nicotinic receptors: structure, function, ligands, and therapeutic potential. ChemMedChem 2, 746-767.

Rovira, J. C., Ballesta, J. J., Vicente-Agullo, F., Campos-Caro, A., Criado, M., Sala, F. \& Sala, S. (1998). A residue in the middle of the M2-M3 loop of the $\beta 4$ subunit specifically affects gating of neuronal nicotinic receptors. FEBS Letters 433, 89-92.

Rovira, J. C., Vicente-Agullo, F., Campos-Caro, A., Criado, M., Sala, F., Sala, S. \& Ballesta, J. J. (1999). Gating of $\alpha 3 \beta 4$ neuronal nicotinic receptor can be controlled by the loop M2-M3 of both $\alpha 3$ and $\beta 4$ subunits. Pflugers Archives 439, 86-92.

Rudolph, U., Crestani, F. \& Mohler, H. (2001). GABA receptor subtypes: dissecting their pharmacological functions. Trends in Pharmacological Science 22, 188-194.

Ruiz-Gomez, A., Vaello, M. L., Valdivieso, F. \& Mayor, JR., F. (1991). Phosphorylation of the 48-kDa subunit of the glycine receptor by protein kinase C. Journal of Biological Chemistry 266, 559-566.

Rundstrom, N., Schmieden, V., Betz, H., Bormann, J. \& LANGosCh, D. (1994). Cyanotriphenylborate: subtypespecific blocker of glycine receptor chloride channels. Proceedings of the National Academy of Sciences USA 91, 8950-8954.

Sali, A. \& Blundell, T. L. (1993). Comparative protein modelling by satisfaction of spatial restraints. Journal of Molecular Biology 234, 779-815.

Sarto-Jackson, I. \& Sieghart, W. (2008). Assembly of $\mathrm{GABA}_{\mathrm{A}}$ receptors (Review). Molecular Membrane Biology 25, 302-310.

Saul, B., Kuner, T., Sobetzko, D., Brune, W., Hanefeld, F., Meinck, H. M. \& Becker, C. M. (1999). Novel GLRA1 missense mutation (P250T) in dominant hyperekplexia defines an intracellular determinant of glycine receptor channel gating. Journal of Neuroscience 19, 869-877.

Schapira, M., Abagyan, R. \& Totrov, M. (2002). Structural model of nicotinic acetylcholine receptor 
isotypes bound to acetylcholine and nicotine. $B M C$ Structural Biology 2, 1.

Schärer, K., Morgenthaler, M., Paulini, R., ObstSander, U., Banner, D. W., Schlatter, D., Benz, J., Stihle, M. \& Diederich, F. (2005). Quantification of cation $-\pi$ interactions in protein-ligand complexes: crystal-structure analysis of factor Xa bound to a quaternary ammonium ion ligand. Angewandte Chemie International Edition: English 44(28), 4400-4404.

Schmidt, A. W. \& Peroutka, S. J. (1989). Three-dimensional steric molecular modeling of the 5-hydroxytryptamine3 receptor pharmacophore. Molecular Pharmacology 36, 505-511.

Schofield, C. M., Jenkins, A. \& Harrison, N. L. (2003). A highly conserved aspartic acid residue in the signature disulfide loop of the $\alpha 1$ subunit is a determinant of gating in the glycine receptor. Journal of Biological Chemistry 278, 34079-34083.

Schreiter, C., Hovius, R., Costioli, M., Pick, H., Kellenberger, S., Schild, L. \& Vogel, H. (2003). Characterization of the ligand-binding site of the serotonin 5-HT $\alpha$ receptor: the role of glutamate residues 97, 224 and 235. Journal of Biological Chemistry 278, 22709-22716.

Schulte, M. K., Hill, R. A., Bikadi, Z., Maksay, G., Parihar, H. S., Joshi, P. \& Suryanarayanan, A. (2006). The structural basis of ligand interactions in the 5-HT3 receptor binding site. In Biological and Biophysical Aspects of Ligand-Gated Ion Channel Receptor Superfamilies (Ed. H. R. Arias), pp. 127-153. Kerala, India: Research Signpost.

Sedelnikova, A., Smith, C. D., Zakharkin, S. O., Davis, D., Weiss, D. S. \& Chang, Y. (2005). Mapping the rho1 $\mathrm{GABA}_{\mathrm{C}}$ receptor agonist binding pocket. Constructing a complete model. Journal of Biological Chemistry 280, 1535-1542.

Sedelnikova, A. \& Weiss, D. S. (2002). Phosphorylation of the recombinant tho1 GABA receptor. International Journal of Developmental Neuroscience 20, 237-246.

Sessoms-Sikes, J. S., Hamilton, M. E., Liu, L. X., Lovinger, D. M. \& MAchu, T. K. (2003). A mutation in transmembrane domain II of the 5-hydroxytryptamine ${ }_{3 \mathrm{~A}}$ receptor stabilizes channel opening and alters alcohol modulatory actions. Journal of Pharmacology and Experimental Therapeutics 306, 595-604.

Shan, Q., Haddrill, J. L. \& Lynch, J. W. (2001). A single $\beta$ subunit M2 domain residue controls the picrotoxin sensitivity of $\alpha \beta$ heteromeric glycine receptor chloride channels. Journal of Neurochemistry 76, 1109-1120.

Shan, Q., Haddrill, J. L. \& Lynch, J. W. (2002). Comparative surface accessibility of a pore-lining threonine residue $\left(\mathrm{T} 6^{\prime}\right)$ in the glycine and $\mathrm{GABA}_{\mathrm{A}}$ receptors. Journal of Biological Chemistry 277, 44845-44853.

Sheridan, R. E. \& Lester, H. A. (1982). Functional stoichiometry at the nicotinic receptor. The photon cross section for phase 1 corresponds to two bis-Q molecules per channel. Journal of General Physiology 80, 499-515.
Shi, J., Blundell, T. L. \& Mizuguchi, K. (2001). FuGUE: sequence-structure homology recognition using environment-specific substitution tables and structuredependent gap penalties. Journal of Molecular Biology 310, 243-257.

SigEL, E. (2002). Mapping of the benzodiazepine recognition site on $\mathrm{GABA}_{\mathrm{A}}$ receptors. Current Topics in Medicinal Chemistry 2, 833-839.

Sigel, E. \& BuHr, A. (1997). The benzodiazepine binding site of $\mathrm{GABA}_{\mathrm{A}}$ receptors. Trends in Pharmacological Science 18, 425-429.

Sigel, E., Buhr, A. \& Baur, R. (1999). Role of the conserved lysine residue in the middle of the predicted extracellular loop between M2 and M3 in the $\mathrm{GABA}_{\mathrm{A}}$ receptor. Journal of Neurochemistry 73, 1758-1764.

Sine, S. M., Wang, H. L., Hansen, S. \& Taylor, P. (2010). On the origin of ion selectivity in the Cys-loop receptor family. Journal of Molecular Neuroscience 40, 70-76.

Slimko, E. M. \& Lester, H. A. (2003). Codon optimization of Caenorbabditis elegans $\mathrm{GluCl}$ ion channel genes for mammalian cells dramatically improves expression levels. Journal of Neuroscience Methods 124, 75-81.

Slimko, E. M., Mckinney, S., Anderson, D. J., Davidson, N. \& Lester, H. A. (2002). Selective electrical silencing of mammalian neurons in vitro by the use of invertebrate ligand-gated chloride channels. Journal of Neuroscience 22, 7373-7379.

Smart, O. S., Goodfellow, J. M. \& Wallace, B. A. (1993). The pore dimensions of gramicidin A. Biophysical Journal 65, 2455-2460.

Spier, A. D. \& Lummis, S. C. (2000). The role of tryptophan residues in the 5-Hydroxytryptamine ${ }_{3}$ receptor ligand binding domain. Journal of Biological Chemistry 275, $5620-5625$.

Spitzmaul, G., Corradi, J. \& Bouzat, C. (2004). Mechanistic contributions of residues in the M1 transmembrane domain of the nicotinic receptor to channel gating. Molecular Membrane Biology 21, 39-50.

Sullivan, N. L., Thompson, A. J., Price, K. \& Lummis, S. C. R. (2006). Defining the roles of Asn-128, Glu-129 and Phe-130 in loop A of the $5-\mathrm{HT}_{3}$ receptor. Molecular Membrane Biology 23, 1-10.

Sun, H., Hu, X. Q., Moradel, E. M., Weight, F. F. \& ZHANG, L. (2003). Modulation of $5-\mathrm{HT}_{3}$ receptormediated response and trafficking by activation of protein kinase C. Journal of Biological Chemistry 278, 34150-34157.

Sunesen, M., De Carvalho, L. P., Dufresne, V., Grailhe, R., Savatier-Duclert, N., Gibor, G., Peretz, A., Attali, B., Changeux, J. P. \& Paas, Y. (2006). Mechanism of $\mathrm{Cl}$ - selection by a glutamate-gated chloride $(\mathrm{GluCl})$ receptor revealed through mutations in the selectivity filter. Journal of Biological Chemistry 281, 14875-14881.

Suryanarayanan, A., Joshi, P. R., Bikadi, Z., Mani, M., Kulkarni, T. R., Gaines, C. \& Schulte, M. K. (2005). 
The loop $\mathrm{C}$ region of the murine $5-\mathrm{HT}_{3} \mathrm{~A}$ receptor contributes to the differential actions of 5-hydroxytryptamine and $\mathrm{m}$-chlorophenylbiguanide. Biochemistry 44, 9140-9149.

Suzuki, T., Koyama, H., Sugimoto, M., Uchida, I. \& Mashimo, T. (2002). The diverse actions of volatile and gaseous anesthetics on human-cloned 5-hydroxytryptamine3 receptors expressed in Xenopus oocytes. Anesthesiology 96, 699-704.

Tamamizu, S., Lee, Y., Hung, B., Mcnamee, M. G. \& Lasalde-Dominicci, J. A. (1999). Alteration in ion channel function of mouse nicotinic acetylcholine receptor by mutations in the M4 transmembrane domain. Journal of Membrane Biology 170, 157-164.

Tamamizu, S., Guzman, G. R., Santiago, J., Rojas, L. V., Mcnamee, M. G. \& Lasalde-Dominicci, J. A. (2000). Functional effects of periodic tryptophan substitutions in the $\alpha$ M4 transmembrane domain of the Torpedo californica nicotinic acetylcholine receptor. Biochemistry 39, 4666-4673.

Tan, K. R., Baur, R., Gonthier, A., Goeldner, M. \& Sigel, E. (2007). Two neighboring residues of loop A of the alpha1 subunit point towards the benzodiazepine binding site of $\mathrm{GABA}_{\mathrm{A}}$ receptors. FEBS Letters 581, 4718-4722.

Tapia, L., Kuryatov, A. \& Lindstrom, J. (2007). $\mathrm{Ca}^{2+}$ permeability of the $(\alpha 4) 3(\beta 2) 2$ stoichiometry greatly exceeds that of $(\alpha 4) 2(\beta 2) 3$ human acetylcholine receptors. Molecular Pharmacology 71, 769-776.

Teissere, J. A. \& Czajkowski, C. (2001). A $\beta$-strand in the $\gamma 2$ subunit lines the benzodiazepine binding site of the $\mathrm{GABA}_{\mathrm{A}}$ receptor: structural rearrangements detected during channel gating. Journal of Neuroscience 21, 49774986.

Thompson, A. J. \& Lummis, S. C. (2003). A single ring of charged amino acids at one end of the pore can control ion selectivity in the $5-\mathrm{HT}_{3}$ receptor. British Journal of Pharmacology 140(2), 359-365.

Thompson, A. J. \& Lummis, S. C. (2006). 5-HT 3 receptors. Current Pharmaceutical Design 12, 3615-3630.

Thompson, A. J. \& Lummis, S. C. (2008a). Calcium modulation of 5-HT3 receptor binding and function. Neuropharmacology 56, 285-291.

Thompson, A. J. \& Lummis, S. C. R. (2008b). Antimalarial drugs inhibit human $5-\mathrm{HT}_{3}$ and $\mathrm{GABA}_{\mathrm{A}}$, but not $\mathrm{GABA}_{\mathrm{C}}$ receptors. British Journal of Pharmacology 153, 1686-1696.

Thompson, A. J., Price, K. L., Reeves, D. C., Chan, S. L., Chau, P. L. \& Lummis, S. C. (2005). Locating an antagonist in the $5-\mathrm{HT}_{3}$ receptor binding site using modeling and radioligand binding. Journal of Biological Chemistry 280, 20476-20482.

Thompson, A. J., Chau, P. L., Chan, S. L. \& Lummis, S. C. (2006a). Unbinding pathways of an agonist and an antagonist from the $5-\mathrm{HT}_{3}$ receptor. Biophysical Journal 90, 1979-1991.
Thompson, A. J., Padgett, C. L. \& Lummis, S. C. (2006b). Mutagenesis and molecular modeling reveal the importance of the 5- $\mathrm{HT}_{3}$ receptor F-loop. Journal of Biological Chemistry 281, 16576-16582.

Thompson, A. J., Lochner, M. \& Lummis, S. C. (2008). Loop B is a major structural component of the $5-\mathrm{HT}_{3}$ receptor. Biophysical Journal 95, 5728-5736.

Tikhonov, D. B., Mellor, I. R. \& Usherwood, P. N. (2004). Modeling noncompetitive antagonism of a nicotinic acetylcholine receptor. Biophysical Journal 87, 159-170.

Trudell, J. R. \& Bertaccini, E. (2004). Comparative modeling of a $\mathrm{GABA}_{\mathrm{A}}$ alpha1 receptor using three crystal structures as templates. Journal of Molecular Graphics and Modelling 23, 39-49.

Tzvetkov, M. V., Meineke, C., Oetjen, E., HirschErnst, K. \& Brockmoller, J. (2007). Tissue-specific alternative promoters of the serotonin receptor gene HTR3B in human brain and intestine. Gene 386, 52-62.

Ulbrich, M. H. \& Isacoff, E. Y. (2007). Subunit counting in membrane-bound proteins. Nature Methods 4, 319321.

UnwIN, N. (1993). Nicotinic acetylcholine receptor at $9 \AA$ resolution. Journal of Molecular Biology 229, 1101-1124.

Unwin, N. (1995). Acetylcholine receptor channel imaged in the open state. Nature 373, 37-43.

Unwin, N. (2000). The Croonian Lecture 2000. Nicotinic acetylcholine receptor and the structural basis of fast synaptic transmission. Philosophical Transactions of the Royal Society of London B: Biological Science 355, 1813-1829.

Unwin, N. (2005). Refined structure of the nicotinic acetylcholine receptor at $4 \AA$ resolution. Journal of Molecular Biology 346, 967-989.

Unwin, N., Miyazawa, A., Li, J. \& Fujiyoshi, Y. (2002). Activation of the nicotinic acetylcholine receptor involves a switch in conformation of the alpha subunits. Journal of Molecular Biology 319, 1165-1176.

Urban, B. W., Bleckwenn, M. \& Barann, M. (2006). Interactions of anesthetics with their targets: nonspecific, specific or both? Pharmacology and Therapeutics 111, 729-770.

Vaello, M. L., Ruiz-Gomez, A., Lerma, J. \& Mayor, Jr., F. (1994). Modulation of inhibitory glycine receptors by phosphorylation by protein kinase $\mathrm{C}$ and cAMPdependent protein kinase. Journal of Biological Chemistry 269, 2002-2008.

Van Hooft, J. A. \& Vijverberg, H. P. (1995). Phosphorylation controls conductance of $5-\mathrm{HT}_{3}$ receptor ligand-gated ion channels. Receptors Channels 3, $7-12$.

Van Hooft, J. A. \& Wadman, W. J. (2003). $\mathrm{Ca}^{2+}$ ions block and permeate serotonin 5-HT3 receptor channels in rat hippocampal interneurons. Journal $p f$ Neurophysiology 89, 1864-1869.

Vassilatis, D. K., Arena, J. P., Plasterk, R. H., Wilkinson, H. A., Schaeffer, J. M., Cully, D. F. \& 
Van Der Ploeg, L. H. (1997). Genetic and biochemical evidence for a novel avermectin-sensitive chloride channel in Caenorbabditis elegans. Isolation and characterization. Journal of Biological Chemistry 272, $33167-$ 33174.

Venkataraman, P., Joshi, P., Venkatachalan, S. P., Muthalagi, M., Parihar, H. S., Kirschbaum, K. S. \& Schulte, M. K. (2002a). Functional group interactions of a $5-\mathrm{HT}_{3} \mathrm{R}$ antagonist. BMC Biochemistry 3, 16.

Venkataraman, P., Venkatachalan, S. P., Joshi, P. R., Muthalagi, M. \& Schulte, M. K. (2002b). Identification of critical residues in loop $\mathrm{E}$ in the 5HT $3_{\mathrm{A}} \mathrm{SR}$ binding site. BMC Biochemistry 3, 15.

Vernekar, S. K., HallaQ, H. Y., Clarkson, G., Thompson, A. J., Silvestri, L., Lummis, S. C. \& Lochner, M. 2010. Toward biophysical probes for the 5-HT3 receptor: structure-activity relationship study of granisetron derivatives. Journal of Medicinal Chemistry 53, 2324-2328.

Vernino, S., Amador, M., Luetje, C. W., Patrick, J. \& DANI, J. A. (1992). Calcium modulation and high calcium permeability of neuronal nicotinic acetylcholine receptors. Neuron 8, 127-134.

Villmann, C., Oertel, J., Ma-Hogemeier, Z. L., Hollmann, M., Sprengel, R., Becker, K., Breitinger, H. G. \& Becker, C. M. (2009). Functional complementation of Glra1(spd-ot), a glycine receptor subunit mutant, by independently expressed C-terminal domains. Journal of Neuroscience 29, 2440-5242.

Violet, J. M., Downie, D. L., NAkisa, R. C., Lieb, W. R. \& Franks, N. P. (1997). Differential sensitivities of mammalian neuronal and muscle nicotinic acetylcholine receptors to general anesthetics. Anesthesiology 86, 866-874.

Wang, M. D. \& Axelrod, D. (1994). Time-lapse total internal reflection fluorescence video of acetylcholine receptor cluster formation on myotubes. Developmental Dynamics 201, 29-40.

Wang, F. \& Iмото, K. (1992). Pore size and negative charge as structural determinants of permeability in the Torpedo nicotinic acetylcholine receptor channel. Proceedings of the Royal Society of London B: Biological Sciences 250, 11-17.

Wang, H. L., Milone, M., Ohno, K., Shen, X. M., Tsujino, A., Batocchi, A. P., Tonali, P., Brengman, J., Engel, A. G. \& Sine, S. M. (1999). Acetylcholine receptor M3 domain: stereochemical and volume contributions to channel gating. Nature Neuroscience 2, 226-233.

Wang, J., Lester, H. A. \& Dougherty, D. A. (2007). Establishing an ion pair interaction in the homomeric $\rho 1 \mathrm{GABA}_{\mathrm{A}}$ receptor that contributes to the gating pathway. Journal of Biological Chemistry 282, 26210-26216.

WebB, T. I. \& Lynch, J. W. (2007). Molecular pharmacology of the glycine receptor chloride channel. Current Pharmaceutical Design 13, 2350-2367.
Wecker, L., Guo, X., Rycerz, A. M. \& Edwards, S. C. (2001). Cyclic AMP-dependent protein kinase (PKA) and protein kinase $\mathrm{C}$ phosphorylate sites in the amino acid sequence corresponding to the M3/M4 cytoplasmic domain of $\alpha 4$ neuronal nicotinic receptor subunits. Journal of Neurochemistry 76, 711-720.

Werner, P., Kawashima, E., Reid, J., Hussy, N., Lundstrom, K., Buell, G., Humbert, Y. \& Jones, K. A. (1994). Organization of the mouse $5-\mathrm{HT}_{3}$ receptor gene and functional expression of two splice variants. Brain Research and Molecular Brain Research 26, 233-241.

Williams, D. B. \& Akabas, M. H. (1999). GABA increases the water accessibility of M3 membrane-spanning segment residues in $\mathrm{GABA}_{\mathrm{A}}$ receptors. Biophysical Journal 77, 2563-2574.

Wilson, G. G. \& KarLin, A. (1998). The location of the gate in the acetylcholine receptor channel. Neuron 20, 1269-1281.

Wilson, G. \& Karlin, A. (2001). Acetylcholine receptor channel structure in the resting, open, and desensitized states probed with the substituted-cysteine-accessibility method. Proceedings of the National Academy of Sciences USA 98, 1241-1248.

Wilson, G. G., Pascual, J. M., Brooijmans, N., Murray, D. \& Karlin, A. (2000). The intrinsic electrostatic potential and the intermediate ring of charge in the acetylcholine receptor channel. Journal of General Physiology 115, 93-106.

Wotring, V. E. \& Weiss, D. S. (2008). Charge scan reveals an extended region at the intracellular end of the GABA receptor pore that can influence ion selectivity. Journal of General Physiology 131(1), 87-97.

Wotring, V. E., Miller, T.S. \& Weiss, D. S. (2003). Mutations at the GABA receptor selectivity filter: a possible role for effective charges. Journal of Physiology 548, 527-540.

Wu, D. F., Othman, N. A., Sharp, D., Mahendra, A., Deeb, T. Z. \& Hales, T. G. (2010). A conserved cysteine residue in the third transmembrane domain is essential for homomeric $5-\mathrm{HT}_{3}$ receptor function. Journal of Physiology 588, 603-616.

Xiu, X., Hanek, A. P., Wang, J., Lester, H. A. \& Dougherty, D. A. (2005). A unified view of the role of electrostatic interactions in modulating the gating of Cys loop receptors. Journal of Biological Chemistry 280, 4165541666.

Xiu, X., Puskar, N. L., Shanata, J. A., Lester, H. A. \& Dougherty, D. A. (2009). Nicotine binding to brain receptors requires a strong cation $-\pi$ interaction. Nature 458, 534-537.

Xu, M. \& Akabas, M. H. (1993). Amino acids lining the channel of the GABAA receptor identified by cysteine substitution. Journal of Biological Chemistry 268, 2150521508.

Xu, M. \& AKabas, M. H. (1996). Identification of channellining residues in the M2 membrane-spanning segment 
of the $\mathrm{GABA}_{\mathrm{A}}$ receptor $\alpha 1$ subunit. Journal of General Physiology 107, 195-205.

Xu, M., Covey, D. F. \& Akabas, M. H. (1995). Interaction of picrotoxin with $\mathrm{GABA}_{\mathrm{A}}$ receptor channel-lining residues probed in cysteine mutants. Biophysical Journal 69, $1858-1867$.

YAKEL, J. L. (2010). Gating of nicotinic ACh receptors: latest insights into ligand binding and function. Journal of Physiology 588, 597-602.

Yakel, J. L., Shao, X. M. \& Jackson, M. B. (1990). The selectivity of the channel coupled to the $5-\mathrm{HT}_{3}$ receptor. Brain Research 533, 46-52.

Yamakura, T., Bertaccini, E., Trudell, J. R. \& Harris, R. A. (2001). Anesthetics and ion channels: molecular models and sites of action. Annual Review in Pharmacology and Toxicology 41, 23-51.

Yan, D., Schulte, M. K., Bloom, K. E. \& White, M. M. (1999). Structural features of the ligand-binding domain of the serotonin $5 \mathrm{HT}_{3}$ receptor. Journal of Biological Chemistry 274, 5537-5541.

YAn, D. \& White, M. M. (2005). Spatial orientation of the antagonist granisetron in the ligand-binding site of the 5- $\mathrm{HT}_{3}$ receptor. Molecular Pharmacology 68, 365-371.

YANG, J. (1990). Ion permeation through 5-hydroxytryptamine-gated channels in neuroblastoma N18 cells. Journal of General Physiology 96, 1177-1198.

Yu, X. M. \& Hall, Z. W. (1994). A sequence in the main cytoplasmic loop of the alpha subunit is required for assembly of mouse muscle nicotinic acetylcholine receptor. Neuron 13, 247-255.

Zhang, H. \& Karlin, A. (1997). Identification of acetylcholine receptor channel-lining residues in the
M1 segment of the beta-subunit. Biochemistry 36, 15856-15864.

Zhang, H. \& Karlin, A. (1998). Contribution of the beta subunit M2 segment to the ion-conducting pathway of the acetylcholine receptor. Biochemistry 37, 7952-7964.

Zhang, L., Oz, M., Stewart, R. R., Peoples, R. W. \& Weight, F. F. (1997). Volatile general anaesthetic actions on recombinant $\mathrm{nACh} \alpha 7,5-\mathrm{HT}_{3}$ and chimeric nACh $\alpha 7-5-\mathrm{HT}_{3}$ receptors expressed in Xenopus oocytes. British Journal of Pharmacology 120, 353-355.

Zhang, D., Gullingsrud, J. \& Mccammon, J. A. (2006). Potentials of mean force for acetylcholine unbinding from the $\alpha 7$ nicotinic acetylcholine receptor ligandbinding domain. Journal of the American Chemical Society 128, 3019-3026.

Zheng, Y., Hirschberg, B., Yuan, J., Wang, A. P., Hunt, D. C., Ludmerer, S. W., Schmatz, D. M. \& Cully, D. F. (2002). Identification of two novel Drosophila melanogaster histamine-gated chloride channel subunits expressed in the eye. Journal of Biological Chemistry 277, 2000-2005.

Zheng, J. \& Zagotta, W. N. (2003). Patch-clamp recording of conformational rearrangements of ion channels. Science Signalling: Signal Transduction Knowledge Environment 176, PL7.

Zuo, Y., Kuryatov, A., Lindstrom, J. M., Yeh, J. Z. \& NARAHASHi, T. (2002). Alcohol modulation of neuronal nicotinic acetylcholine receptors is alpha subunit dependent. Alcoholism: Clinical and Experimental Research 26, 779-784. 